\title{
SENI LUKIS \\ KONSEP DAN METODE
}

\section{Tri Aru Wiratno}

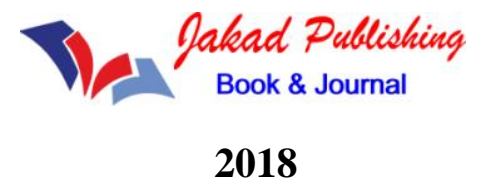




\title{
PERPUSTAKAAN NASIONAL REPUBLIK INDONESIA \\ KATALOG DALAM TERBITAN (KDT)
}

\section{SENI LUKIS, KONSEP DAN METODE}

\author{
Penulis \\ Tri Aru Wiratno \\ Desain Cover \\ Rio Wednri Wijaya \\ Layout \\ Lutfiah \\ Setyaningrum \\ Copyright ( 2018 Jakad Publishing \\ Surabaya \\ Diterbitkan \& Dicetak Oleh \\ CV. Zifatama Jawara \\ Group Of Jakad Publishing Surabaya 2018 \\ Jl. Gayung Kebon Sari I No. 1 Surabaya \\ Telp. : 081234408577 \\ E-mail : jakadmedia@gmail.com \\ IKAPI No. 149/JTI/2014
}

ISBN : 978-602-5815-08-9

Hak cipta dilindungi oleh Undang-undang

Ketentuan Pidana Pasal 112 - 119

Undang-undang Nomor 28 Tahun 2014

Tentang Hak Cipta.

Dilarang keras menerjemahkan, memfotokopi, atau memperbanyak sebagian atau seluruh isi buku ini tanpa izin tertulis dari penerbit 


\section{KATA PENGANTAR}

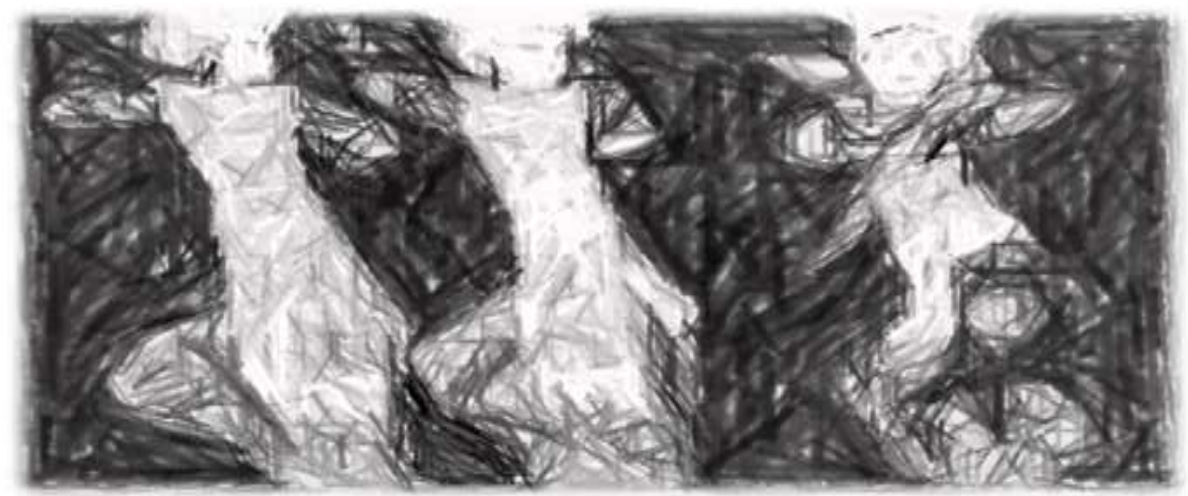

Segala puji syukur kepada Allah SWT yang telah memberikan karunia dan rahmatnya, sehingga bisa membuat bahan pembelajaran Seni Lukis di dalam mempelajari seni lukis. Sebagai upaya melengkapi proses pembelajaran seni lukis yang terstruktur dengan tahapan - tahapan untuk mencapai apa yang menjadi tujuan pembelajaran seni lukis, yaitu berkarya seni lukis dengan kemampuan pengetahuan ilmu seni.

Membuat seni lukis sebagai landasan berkarya yang mengikuti kaidah seni lukis dengan baik dan mampu menguasai konsep berkarya dan teknik seni lukis. Selanjutnya seni lukis menjadi landasan berkarya dengan pengetahuan seni di masa yang akan datang sesuai dengan perkembangan setiap pelukis di dalam mengembangkan dirinya.

Dengan berkarya seni melampaui kaidah - kaidah seni lukis menjadi karya seni kontemporer. Namun tidak kehilangan landasan berkarya baik dalam menguasai material, media, elemen seni lukis dan konsep gagasan berkarya. Membuat karya seni lebih bermakna dalam mengungkapkan dengan berbagai material dan media, serta teknik dan konsep seni dengan melihat pengetahuan seni menjadi pemahamannya dalam berkarya seni. 
Mampu mengelola tahapan di dalam membuat karya seni secara baik dan terstruktur. Tanpa kehilangan spirit dan sensitivitas, sentuhan dari jiwa dan rasa yang mampu menang-kap nilai serta memaknakan menjadi sebuah ungkapan karya seni yang bisa dirasakan dan dipahami dalam tataran pengetahuan seni.

Karya seni lukis telah memberikan landasan berkesenian dengan memahami dan mampu mengembangan pontensi diri seorang pelukis menjadi seorang seniman yang memberikan aspek kehidupan dalam pola kesenian yang mencakup keseluruhan seorang seniman mulai dari kemampuan teknis, rasa, pengetahuan seni dan memformulasi kesenian menjadi sebuah karya seni yang mampu diapresiasi oleh sebuah kalangan.

Hal ini dikarenakan seorang pelukis atau seorang seniman di dalam membuat karya seni, lahir bukan pada areal kosong dalam kehidupan manusia. Tetapi lahir dari areal yang memfasilitasi dirinya menjadi seorang pelukis dan seniman, dalam atmosfer kehidupan masyarakat dimana dia berada dalam konstelasi kehidupannnya.

Dengan demikian karya seni lukis dan lebih lanjut karya seni lahir dari basis realitas sosial budaya masyarakatnya. Sebagai kesadaran diri dan kerendahan hati untuk selalu bersentuhan agar bisa merasakan dan menjadi bahan refleksi diri dalam menjalin kehidupannya dalam dunia seni. Dengan mengadakan konfirmasi dan validasi dari proses berkesenian, serta langkah-langkah yang diambilnya sebagai sebuah keputusan yang lahir dari realitas sosial budaya.

Tanpa harus meniadakan diri sebagai seorang pelukis atau seniman, tanpa terbatas pada dunia seni, atau sebaliknya seni hanya mengikut perkembangan masyarakatnya tanpa mampu melihat realitas diri dalam berkesenian. Dua hal ini untuk saling berinteraksi dalam rangka untuk keseimbangan dan har- 
monisasi bertujuan untuk menghasilkan karya seni yang memang bukan dalam ruang yang hampa, atau terjebak pada mekanis komodite, tanpa melihat kultur seorang pelukis atau seniman dalam realitas sosial budaya masyarakatnya.

Dengan demikian buku seni lukis ini hanya awal dari bagaimana pembelajaran seni lukis sebagai tumpuhan dalam mengembangkan diri untuk lebih baik dan menguasai apa yang menjadi passionnya seorang pelukis atau seniman dari tujuan pembelajaran yang dilakukannya.

Untuk bisa dipahami dan dikelola hingga menjadi kemampuan yang lebih baik dan berkembangan sesuai dengan perkembangan setiap orang yang banyak memberikan kemungkinan di dalam berkarya, apa lagi berkarya seni.

Akhirnya harus disadari bahwa bahan pembelajaran seni lukis ini sebagai upaya, untuk pembelajaran yang lebih komperhensif lagi dalam seni lukis. Meskipun masih banyak kekurangan, yang luput dari jangkau dan kealpaan. HI ini disebabkan keterbatasan dari penulis yang mungkin akan bisa disempurnakan oleh yang lain dalam waktu mendatang sehingga pembelajaran seni lukis lebih tercatat dengan baik. Dalam melihat perkembangan karya seni lukis atau dari landasarn seni lukis melahirkan karya seni, pengetahuan seni, restorasi karya seni, kritik seni dan kuratorial seni.

Hal ini terlihat bahwa pembelajaran seni lukis sebagai landasan berkesenian akan memberikan kemungkinan pada pengembangan seni yang lebih baik lagi, dan pada akhirnya sejarah telah membuktikan seni lukis berkembang menjadi seni kontemporer.

Tangerang, 2018

Penulis 
Seni Lukis, Kansep dan Metade 


\section{DAFTAR ISI}

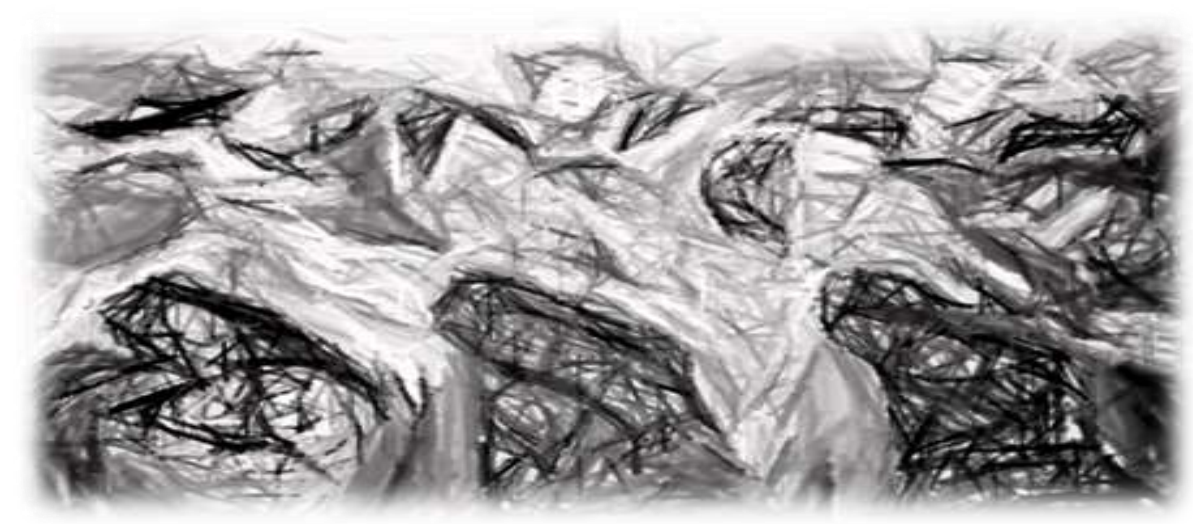

Halaman Judul.

Kata Pengantar................................................................. lii

Daftar Isi............................................................................ Vi

Daftar Gambar................................................................ X Xi

Pendahuluan.................................................................... 1

BAB I Gagasan dan Kreativitas Berkarya Seni Lukis... 21 Konsep Gagasan Seni Lukis................................ $\quad 25$

Proses Kreatif................................................... 39

Metodologi Kreatif....................................... 43

Belajar Melukis................................................ $\quad 50$

Model Pembelajaran Seni Lukis.......................... 54

Pengembangan Kreativitas Seni Lukis.................. $\quad 72$

Contoh Karya............................................... $\quad 77$

Glosarium............................................ 80

Daftar Isi................................................. $\quad 82$

BAB II Konsep Dasar Seni Rupa.................................. 83

Teori Dasar Seni Rupa...................................... $\quad 86$

Pengertian Seni lukis......................................... 113

Proses Berkarya Seni Lukis............................... $\quad 120$

Karya Seni Lukis............................................... 128

Contoh Karya ............................................. 133 
Glosarium............................................... 135

Daftar Isi............................................... 136

BAB III Konsep Realitas Sosial Budaya...................... 137

Seni Lukis dan Realitas Sosial Budaya.............. 139

Contoh Karya................................................. 161

Glosarium.................................................. 163

Daftar Isi...................................................... 164

BAB IV Makna Alam Benda Figur dan Lingkungan 165

Realitas Sosial Budaya.....................................

Strategi Berkarya Seni Lukis............................. 177

Contoh Karya................................................. 187

Glosarium............................................... 190

Daftar Isi.................................................. 191

BAB V Teknik Sapuan Halus, Kasar dan Ekspresif..... 193

Teknik Seni lukis............................................. 195

Konsep Sapuan Halus, Kasar dan Ekspresif....... 198

Karakter dan Jenis Kuas................................... $\quad 207$

Contoh Karya............................................... $\quad 224$

Glosarium............................................. 225

Daftar Isi....................................................... 228

BAB VI Melukis dengan Berbagai Gaya........................ 229

Gaya Lukisan.............................................. $\quad 230$

Contoh Karya.............................................. 243

Glosarium............................................ 244

Daftar Isi................................................. $\quad 245$

BAB VII Melukis dengan Teknik Dasar di Berbagai 247

Media.

Melukis Dengan Berbagai Media....................... $\quad 249$

Pengembangan Teknik dan Gagasan Seni Lukis $\quad 250$

Contoh Karya.................................................. 267 
Glosarium.............................................. 269

Daftar Isi............................................... $\quad 270$

BAB VIII Interpretasi Alam Benda, Figur dan 271

Lingkungan Dalam Karya Lukisan....................

Interpretasi Tema Lukisan................................. 273

Teknik Seni Lukis dan Kesadaran Realitas Sosial 286

Budaya.

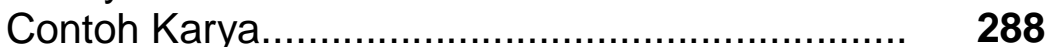

Glosarium................................................ 289

Daftar Isi............................................... 291

BAB IX Mempresentasikan Karya Lukisan................... 293

Presentasi Karya Lukisan................................. 296

Menguasai Karya Seni Lukis Realitas ............... 298

Sosial Budaya.

Contoh Karya............................................. $\quad 300$

Glosarium............................................... 302

Daftar Isi.............................................. 303

BAB X Seni Lukis Berbasis Realitas Sosial Budaya.... 305

Seni Lukis Berbasis Realitas Sosial Budaya......... 307

Menguasai Teknik Seni Lukis. .......................... $\quad 310$

Contoh Karya.................................................. 336

Glosarium.......................................... 338

Daftar Isi................................................. 340

BAB XI Pameran Karya Seni Lukis................................ 341

Pameran Karya Seni Lukis............................... $\quad 345$

Penyelenggaraan Pameran Seni Lukis............... $\quad 350$

Pedoman Pameran Seni Lukis........................... $\quad 359$

Contoh Karya.......................................... 362

Glosarium................................................... 364

Daftar Isi......................................................... $\quad 365$ 
Seni Lukis, Kansep dan Metade 


\section{DAFTAR GAMBAR}

Gambar 1. Karya lukisan Vincent van Gogh 26

"Slaapkamer te Arles"

Gambar 2. Skema konsep berkarya dan 31

pemahaman berkarya

Gambar 3. Proses munculnya Ide 32

Gambar 4. Skema Gagasan berkarya seni lukis $\quad 35$

Gambar 5. Lukisan Self Potret karya Vincent van 38

Gogh

Gambar 6. Skema Kemampuan berpikir Kreatif 41 seorang pelukis

Gambar 7. Skema Metodologi Kreativitas dan 45

Gambar 8. Lukisan Gerak Bumi Karya Aru 47

Gambar 9. Pembelajaran Melihat karya lukisan di 52

Pameran

Gambar 10. Skema Model Pembelajaran Seni Lukis 58

Gambar 11. PERSAGI, Perkumpulan Pelukis 60 Indonesia

Gambar 12. Model pembelajaran seni lukis berbasis 62 realitas sosial budaya

Gambar 13. Lahirnya gagasan dan kreativitas, 69 bersama pelukis Srihadi Soedarsono

Gambar 14. Lukisan Surealisme, Salvador Dali, 73 Apparition of Face and Vase on a Beach

Gambar 15. Pengembangan Kreativitas Seni Lukis 75

Gambar 16. Suasana studio lukis Picasso 76

Gambar 17. Lukisan Poster Kemerdekaan Indonesia 77 karya Affandi

Gambar 18. Lukisan Monalisa dan wajah Leonardo 78 da vinci

Gambar 19. Siklus Teori Karya Seni Lukis 87

Gambar 20. People walk on the monumental 92 installation entitled The Floating Piers' created by artist Christo

Gambar 21. Renungan Malam Mei 1978 Karya 95 


\begin{tabular}{|c|c|c|}
\hline & Lukisan Nashar & \\
\hline Gambar 22. & Lukisan Piet Mondrian & 96 \\
\hline Gambar 23. & Boardwalk wallpaper mural & 98 \\
\hline Gambar 24. & Kids Bedroom-Landscape-Murals & 100 \\
\hline Gambar 25. & Self Potret karya Rembrand & 102 \\
\hline Gambar 26. & $\begin{array}{l}\text { Messieurs les Voyageurs on their } \\
\text { Return from Italy (1829) karya William } \\
\text { Turner }\end{array}$ & 103 \\
\hline Gambar 27. & $\begin{array}{l}\text { Luncheon of the Boating Party by } \\
\text { Pierre-Auguste Renoir (1881) }\end{array}$ & 104 \\
\hline Gambar 28. & $\begin{array}{l}\text { "Arab attacked by Lion" by Raden } \\
\text { Saleh, Year: } 1811-1880\end{array}$ & 107 \\
\hline Gambar 29. & $\begin{array}{l}\text { Skema karya seni lukis dalam elemen } \\
\text { dasar seni rupa }\end{array}$ & 109 \\
\hline Gambar 30. & Lukisan Irama Daun, karya Aru & 112 \\
\hline Gambar 31. & Lingkup Pengertian Seni lukis & 120 \\
\hline Gambar 32. & $\begin{array}{l}\text { Lukisan terlihat realitas sosial budaya } \\
\text { Indonesia }\end{array}$ & 126 \\
\hline Gambar 33. & Lukisan Karya Sudjojono & 132 \\
\hline Gambar 34. & $\begin{array}{l}\text { Srihadi Soedarsono, Lukisan I, } 83 \mathrm{~cm} \mathrm{x} \\
97 \mathrm{~cm} \text {, Oil on canvas }\end{array}$ & 146 \\
\hline Gambar 35. & $\begin{array}{l}\text { Skema proses karya seni lukis berbasis } \\
\text { realitas sosial budaya }\end{array}$ & 147 \\
\hline Gambar 36. & $\begin{array}{l}\text { Borobudur Alam Meditasi karya Srihadi } \\
\text { Soedarsons } 1994 \text { Cat minyak di kanvas }\end{array}$ & 149 \\
\hline Gambar 37. & $\begin{array}{l}\text { Lukisan Wayang karya Srihada } \\
\text { Soedarsono }\end{array}$ & 152 \\
\hline Gambar 38. & $\begin{array}{l}\text { Relasi Seni Lukis Realitas Sosial } \\
\text { Budaya }\end{array}$ & 157 \\
\hline Gambar 39. & Lukisan Sudjojono jamu tradisional & 161 \\
\hline Gambar 40. & $\begin{array}{l}\text { Bedaya Ela Ela, Srihadi Soedarsono, } \\
200 \mathrm{~cm} \times 130 \mathrm{~cm} \text {, Oil on canvas }\end{array}$ & 162 \\
\hline Gambar 41. & Strategi Berkarya Seni Lukis & 180 \\
\hline Gambar 42. & $\begin{array}{l}\text { Skema Tahapan membuat karya seni } \\
\text { lukis }\end{array}$ & 183 \\
\hline Gambar 43. & Skema memaknai dalam membuat & 186 \\
\hline
\end{tabular}




\begin{tabular}{|c|c|c|}
\hline & karya seni lukis & \\
\hline Gambar 44. & $\begin{array}{l}\text { Lukisan Guernica (masterpiece) Pablo } \\
\text { Picasso }\end{array}$ & 187 \\
\hline Gambar 45. & $\begin{array}{l}\text { Lukisan Monalisa karya Leonardo da } \\
\text { Vinci }\end{array}$ & 188 \\
\hline Gambar 46. & George Digby, 2nd Earl of Bristol & 201 \\
\hline Gambar 47. & $\begin{array}{l}\text { Lukisan Abstrak Ekspresionisme, karya } \\
\text { Williem de Kooning }\end{array}$ & 203 \\
\hline Gambar 48. & $\begin{array}{l}\text { Vassily Kandinsky, Composition VI, } 195 \\
\text { x } 300 \mathrm{~cm} \text {, oil on canvas,1913, at Saint } \\
\text { Petersburg }\end{array}$ & 206 \\
\hline Gambar 49. & Skema membuat karya seni lukis & 208 \\
\hline Gambar 50. & Flat, shader \& Wash / Glaze & 209 \\
\hline Gambar 51. & Filbert, Cat's Lidah \& Wash Oval & 211 \\
\hline Gambar 52. & Sudut Flat & 214 \\
\hline Gambar 53. & Kuas Blender & 216 \\
\hline Gambar 54. & Round, Round Stroke dan Ultra Round & 215 \\
\hline Gambar 55. & Kuas Scrit Liner & 215 \\
\hline Gambar 56. & $\begin{array}{l}\text { Scrit Liner, Garis Panjang, Garis } \\
\text { Pendek dan scroller }\end{array}$ & 216 \\
\hline Gambar 57. & Jenis kuas Fan & 218 \\
\hline Gambar 58. & Flat ukuran besar & 219 \\
\hline Gambar 59. & $\begin{array}{l}\text { Lukisan dengan mempergunakan kuas } \\
\text { flat besar }\end{array}$ & 220 \\
\hline Gambar 60. & $\begin{array}{l}\text { Pisau Palet salah satu media teknik seni } \\
\text { lukis }\end{array}$ & 220 \\
\hline Gambar 61. & Goresan mengunakan pisau palet & 221 \\
\hline Gambar 62. & $\begin{array}{l}\text { Ada beberapa jenis Pisau Palet dalam } \\
\text { melukis }\end{array}$ & 222 \\
\hline Gambar 63. & Lukisan mempergunakan pisau palet & 223 \\
\hline Gambar 64. & $\begin{array}{l}\text { Ngarai Sihanok Minangkabau, karya } \\
\text { Basuki Abdullah }\end{array}$ & 233 \\
\hline Gambar 65. & $\begin{array}{l}\text { Detail lukisan Penangkapan } \\
\text { Diponegoro; ekspresi wajah Diponegoro } \\
\text { dan De Kock }\end{array}$ & 234 \\
\hline Gambar 66. & $\begin{array}{l}\text { "The Sleeping Spinner” karya Gustav } \\
\text { Courbet }\end{array}$ & 235 \\
\hline
\end{tabular}


Gambar 67. Lukisan Itji Tarmizi 238

Gambar 68. Saint Marco di Venetsia, karya Affandi 240

Gambar 69. Jackson Pollock sedang melukis 242

Gambar 70. Lukisan mural di plaza 252

Gambar 71. Pengembangan di dalam membuat 253

karya seni lukis

Gambar 72. Lukisan Kapel Sistina 255

Gambar 73. Mural Diego Rivera's menggambarkan 256

sejarah Meksiko di Istana Nasional di

Mexico City

Gambar 74. Lukisan Jasper Johns, Three Flags 259

Gambar 75. That Gentleman karya Andrew Wyeth 263

Gambar 76. Jan van Eyck "Man in a Red Turban" 265

Gambar 77. Media cat dalam karya seni lukis 267

Gambar 78. Garai Sihanok karya Wakidi 276

Gambar 79. Lukisan Abstrak Jackson Pollock 277

Gambar 80. Lukisan Karikatural Heri Dono 278

Gambar 81. Adele Bloch-Bauer 1907 karya Gustav 282

Gambar 82. Lukisan mural, mitos malaikat 285

Gambar 83. Skema seni lukis menjadi sikap seorang 288

Gambar 84. Mahasiswa sedang mempresentasikan 329

karyanya di Galery II Taman Ismail

Marzuki

Gambar 85. Skema mempersiapkan pameran 300

lukisan bersama

Gambar 86. Skema mengevaluasi karya seni lukis 311

dalam pameran

Gambar 87. Taos Mountain, Trail Home oleh

Cordelia Wilson Lanskap awal abad ke-

20 teknik impasto

Gambar 88. Tebing dan celah-celah oleh Jane Frank (1960) Abstrak ekspresionis

Gambar 89. Lukisan Vincent van Gogh

Gambar 90. Karya lukisan Frank Auerbach 316

Gambar 91. Lukisan Monalisa karya Leonardo da 318 


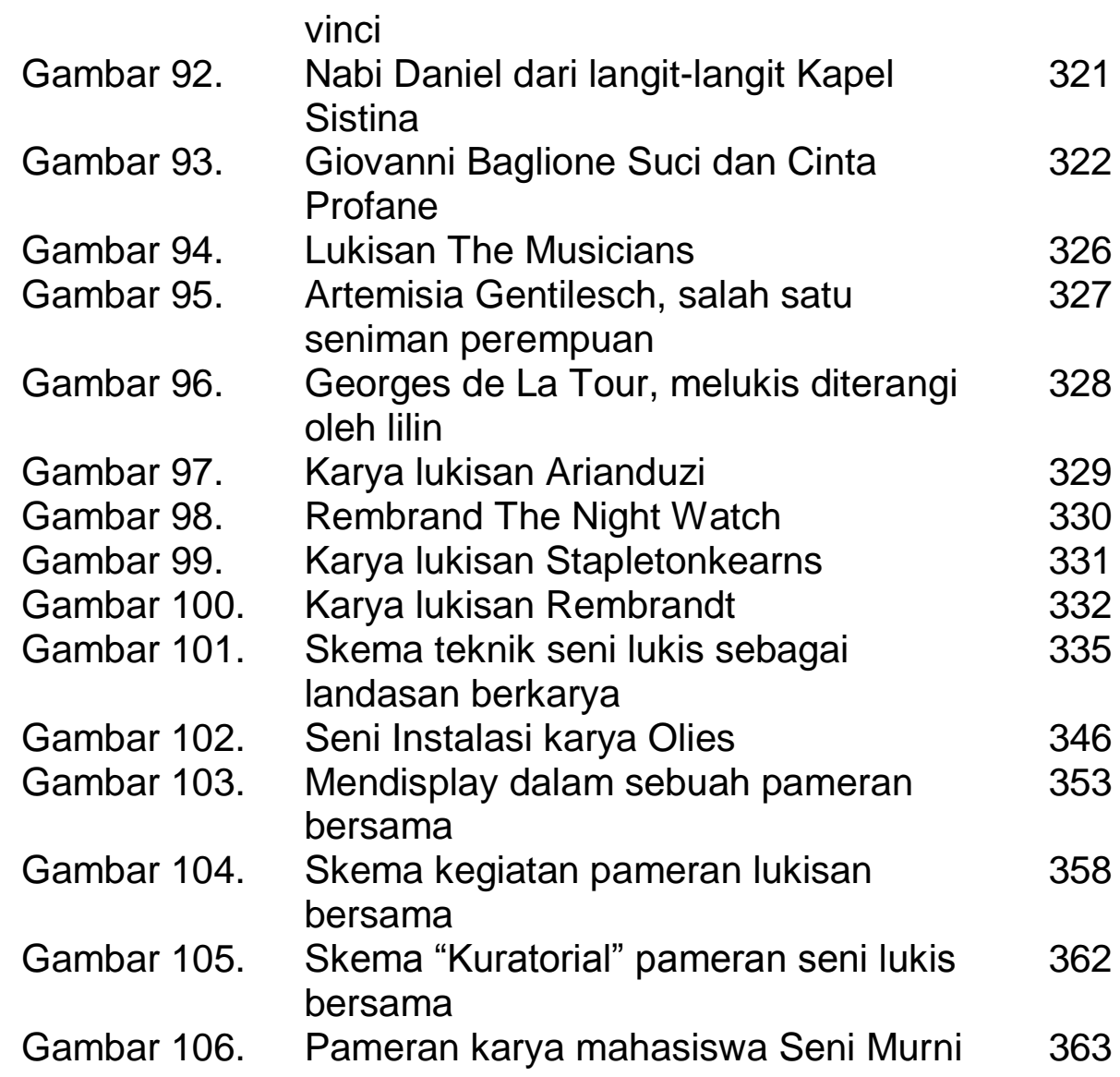




\section{PENDAHULUAN}
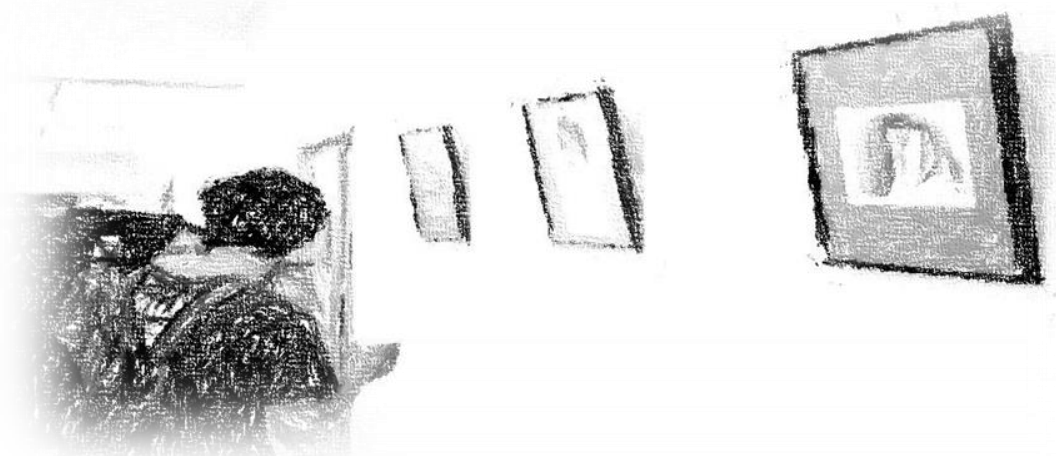

$1 \begin{aligned} & \text { enjelaskan kegiatan perkuliahan seni lukis dengan } \\ & \text { materi perkuliahan dan aturan secara keseluruhan } \\ & \text { yang diberikan selama satu semester. Materi per- }\end{aligned}$ kuliahan seni lukis yang diberikan dalam empat belas kali pertemuan. Setiap perkuliahan di mulai dengan pemahaman dan penjelasan seni lukis dan tugas karya.

Hal ini diharapkan agar setiap mahasiswa dapat lebih memahami dan mampu mengembangkan konsep gagasan dan metodologi seni lukis dalam riset dan kemampuan teknik. Dengan harapan kemampuan mahasiswa sebagai seorang pelukis bisa melukis secara akademis, berangkat dari riset, berdasarkan pengamatan, pengalaman dan internalisasi diri. Kemudian dibuat prosedur berkarya seni lukis, sehingga lahirnya sebuah karya menjadi pengetahuan yang bermakna bagi dirinya. Seorang pelukis tahu tahapan dan prosedur di dalam membuat karya seni lukis.

Belajar seni lukis bukan saja bagaimana bisa melukis dengan baik dan mampu. Tetapi juga belajar seni lukis mengetahui bagaimana sebuah karya seni menjadi sebuah karya seni. Sejalan dengan perkembangan zaman, yang disebut dengan seni bukan 
saja dari karya seninya tapi dari pengetahuan seni. Karya seni lahir bukan saja dari kemampuan teknik membuat karya, tapi juga mempunyai pengetahuan seni, yang menjadi karya itu disebut dengan seni.

Jika mahasiswa menjadi seorang pelukis dan pekerja seni mempunyai kesadaran model kerja seperti itu dan juga mengetahui serta mampu melakukan tahapan metodologi dan riset dalam tema dan pengetahuan teknik membuat karya seni lukis yang diberikan, maka harapannya akan lebih dikembangkan lagi oleh mahasiswa.

Dalam mengerjakan karya lukisan bukan saja melukis secara intuitif, tetapi juga mengetahui dan mampu mengerjakan tahapan dalam metodologi dan konsep melukis. Hal tersebut dapat diselesai dengan waktu minimal dua minggu dalam satu karya.

Disetiap menyelesaikan karya lukisannya akan dilakukan pertemuan untuk didiskusikan, sehingga akan memperkuat kemampuan berkarya dan memperkaya dalam berkarya.

Dalam pertemuan itu akan ada penilaian sebagai apresiasi didalam proses berkarya. Penilaiannya melingkupi konsep gagasan, metode berkarya dengan interpretasi sesuai dengan tema berbasis realitas sosial budaya. Sebagai apa yang menjadi perkembangan di dalam pertemuan tersebut. Meskipun ada kesepakatan bersama dilakukan ketika dalam diskusi yang lebih bersifat memperbaiki dan memperkuat berkarya seni lukis.

Dengan demikian tugas karya lukisan, diharapkan mampu mencapai kemampuan yang maksimal. Berdasarkan indikator yang telah dijelaskan sebelumnya, sehingga menjadi kesepakatan pertemuan yang dibuat. Yaitu membuat karya lukisan berbasis realitas sosial budaya, wujud dari cara pandangan seorang pelukis. Dengan metodologi riset dan prosedural yang dibuat oleh mahasiswa dan seorang pelukis. Pandangan seorang pelukis berupa gagasan seni lukis, yang lahir dari apa yang terjadi. 
Karya lukisan menjadi karakter budaya bangsa yang sifatnya lebih dinamis. Realitas sosial budaya bukan saja berkaitan dengan tradisi, nilai budaya, norma dan nilai agama yang beraneka ragam, tetapi realitas sosial budaya menjadi bentuk keseluruhan dari sebuah kehidupan masyarakat, dalam berbangsa dan bernegara.

Hal tersebut sebagai bentuk bhineka tunggal ika dari bangsa Indonesia yang mempunyai realitas sosial budaya yang dinamis dalam perkembangan teknologi dan informasi. Meskipun tidak lepas dari pengaruh dan perkembangan realitas sosial budaya dunia secara global.

Realitas sosial budaya Indonesia menjadi bagian dari kehidupan berbangsa dan bernegara dalam pergaulan internasional. Menjadi kesadaran setiap pelukis, untuk melihat realitas sosial budaya seni lukis bukan pada masalah karya seninya saja, akan tetapi bagaimana seorang pelukis membuat karya lukisan menjadi bagian dari kehidupan realitas sosial budaya sebagai konsep dan kesadaran bermasyarakat.

Di dalam setiap pertemuan dalam perkuliahan, dengan memberikan materi secara diskripsi. Perkuliah itu juga dilengkapi dengan pertemuan pembimbingan karya. Dalam pembimbingan karya seni lukis juga dilakukan mahasiswa dengan mempresentasikan dan juga menjelaskan gagasan melukis. Dengan menjelaskan konsep dan metodologi riset dan berkarya seni lukisnya.

Dengan harapkan akan memberikan muatan nilai dalam berkarya seni lukis secara keseluruhan. Bersama dengan metodologi riset membuat karya seni lukis dengan mempergunakan semiotika. Membuat mahasiswa akan terbiasa dengan membuat karya lukisan dengan sistem tanda dan interpretasi dan juga menjadi metodologi dan riset sebagai pola berpikir dan berkarya dengan indaktor yang terukur, tanpa menghilangkan rasa. 
Kekuatan ekspresinya sebagai seorang pelukis di dalam berkarya akan membuat lukisan itu memberikan sebuah pemahaman yang bisa menjadi pertimbangan atau pengembangan bagi karya seni lukis yang sedang dalam tahapan penyelesaian. Dengan demikian karya lukisan yang dibuatnya, atau menjadi inspirasi dan gagasan pada karya seni lukis, bisa jadi karya selanjutnya.

Nilai dari isi materi seni lukis sebagai konsep dan metodologi yang disampaikan menjadi bagian dari proses membuat karya lukisnya sebagai seorang pelukis. Sebagai seorang pelukis hal itu menjadi aspek pedukung di dalam berkesenian. Karena metodologi dan riset aspek kesatuan bekarya yang dinyatakan dalam melukis. Menjadi bagian dari pertemuan ini membicarakan lukisan dari aspek metodologi siomiotika dan interpretasi budaya dalam perkembangan realitas sosial budaya. Materi tersebut yang akan menjadi subject matter dari karya seni lukis.

Berkaitan dengan hal tersebut, proses seni lukis dengan beberapa tahapan diantaranya bagaimana mempergunakan gagasan, kreativitas dan mengelola teknik sebagai pengetahuan berkarya seni lukis. Dalam membuat tahapan seorang pelukis akademis tersebut, mampu mempergunakan bagan atau skema, agar bisa dipahami dan terlihat dengan baik. Karya lukisan ini menjadi bagian struktur yang terkoordinasi, begitu juga dengan menginterpretasi tema lukisan dalam berkarya.

Diharapkan mahasiswa dapat membangun ide dan gagasan realitas sosial budaya. Dengan mempergunakan pengamatan dan riset sebagai penguat dan pembentukan suasana secara keseluruhan dalam lukisannya. Menjadikan karya lukisan itu satu kesatuan dari aspek formal seni yang terdiri dari garis, sapuan kuas, warna, bentuk, ruang, bidang dan komposisi dalam internalisasi serta implementasi dalam berkarya seni lukis. 
Untuk mencapai tujuan pembelajaran seni lukis yang diharapkan dalam pertemuan dalam membahas materi karya seni lukis. Untuk itu dapat menyelesaikan karya seni lukis itu, ada indikator penilaian yang dibuatnya. Kemampuan seorang pelukis di dalam menginterpretasikan tema lukisan dalam karya lukisnya. Dengan demikian penilaian dimulai dengan ide dan gagasan melukis.

Kemudian dilanjutkan dengan proses berkarya, bagaimana gagasan dan kreativitas, berserta kemampuan teknik melukis dengan baik. Membuat karya lukisan itu menjadi karya lukis identitas skala kecil dan besar. Di mana skala kecil menjadi khas seorang pelukis yang berbeda karya dengan orang lain, meskipun bentuk dan gaya sama. Sedangkan dalam skala besar memang karya lukisannya itu mempunyai kekhas yang baru, seperti karya lukisan Pablo Picasso, yang menemukan gaya lukisan kubisme. Selain itu kemampuan interpretasi tema dalam berkarya bisa diimplementasikan dalam karya seni lukis yang visioner.

Dengan membuat karya lukisan mahasiswa sebagai seorang pelukis diharapkan mampu membuat karya lukisannya sesuai dengan pengetahuan yang dilakukan secara bertahap.

Mahasiswa juga diharapkan dapat membuat delapan karya seni lukis yang mempresentasikan konsep gagasannya. Dari hasil karya lukisan itu dapat terlihat dan mengetahui sejauh mana mahasiswa dalam mencapai tujuan pembelajaran seni lukis dan menginterpretasikan realitas sosial budaya.

Proses berkarya yang berjalan ini dilakukan dengan cara mengadakan diskusi dialogis, sebagai bentuk presentasi karya. Kepada setiap mahasiswa untuk tampil secara satu persatu dengan membawa hasil sebuah karya lukisan untuk menjelaskan konsep gagasan dan metodologi.

Dengan menjelaskan tahapan berkaryanya juga pada saat presentasi karyanya. Secara bergantian, sehingga mahasiswa satu 
dengan yang lainnya saling belajar dan menginspirasikan serta memperkuat dalam berkarya seni lukis.

Bahwa sebagai seorang pelukis bukan saja menguasai teknik melukis, tetapi juga menjelaskan dengan baik. Mulai dari gagasan, konsep melukis, tahapan dalam metodologi melukis, dan teknik melukis. Sebagai representasi seorang pelukis yang mempunyai kesadaran untuk mengevaluasi dan mengembangkan serta menemukan dalam beberapa hal untuk menerapkan pengetahuan dan pengalamannya.

Setelah itu mampu melihat semua itu menjadi sebuah kesadaran bagi seorang pelukis. Sebagai sikap dan berempati terhadap permasalahan yang ada dalam realitas sosial budaya masyarakat. Baik yang ada sebelumnya, maupun yang sedang berjalan dan mengalami perkembangan dan kemajuan sejalan dengan perkembangan zamannya.

Untuk memperlihatkan bahwa membuat karya seni lukis bukan permasalahan karya seni atau masalah teknis. Begitu juga di dalam membuat karya lukisan, bukan permasalahan pengetahuan seni secara akademis, akan tetapi membuat karya seni lukis adalah permasalahan konstruksikan hidup dan nilai kehidupan seorang pelukis pada realitas sosial budaya.

Bahwa seni lukis bukan hanya aspek bentuk dan kesenangan semata, tetapi menjadi sebuah representasi dari realitas kehidupan. Begitu juga lukisan bagi seorang pelukis dan masyarakat dari sebuah bangsa yang memperlihatkan seni lukis dari kehidupan. Mempunyai nilai kehidupan manusia, karena seni lukis bagian dari kehidupan manusia yang mempunyai nilai yang bermakna dalam arti lebih luas lagi.

Karya lukisan bisa dilihat dari berbagai macam aspek kehidupan dan ilmu pengetahuan. Meskipun seni lukis tetap pada proporsinya sebagai karya lukisan. Aspek kesenilukisan menjadi dasar dalam berkarya seni lukis. 


\section{Tahapan Pembelajaran Seni Lukis}

Bahan ajar ini dibagi menjadi sebelas pembahasan yang berkaitan dengan kompetensi. Di dalam kemampuan membuat konsep, tahapan metodologi berkarya dan membuat karya lukisan. Dengan mengikuti tahapan dan pemahaman di dalam memperkaya proses berkarya.

Seorang pelukis bukan hanya mampu melukis, tetapi juga mempunyai pandangan, pengetahuan seni dan kehidupan yang menjadi komunitasnya. Pembelajaran ini sebagai gambaran materi perkuliahan seni lukis ini, sebagai berikut :

Bab 1 Materi pembahasan yang disampaikan mengenai konsep gagasan dan kreativitas berkarya seni lukis. Sebagai awal dalam proses berpikir dan merasakan pengalaman sebagai internalisasi. Bahwa berkarya merupakan satu kesatuan, sehingga harus merepresentasikan dalam konteks realitas sosial budaya.

Dengan demikian munculnya gagasan dan kreativitas yang selalu mendorong untuk berkarya atau melakukan sesuatu yang lebih terstruktur. Meskipun di dalam perkembangannya tidak selalu harus terstruktur, tergantung pada permasalahan dan kontekstulitas yang dihadapinya.

Pedekatan metodologi semiotik dan interpretasi dalam membuat karya lukisan. Diharapkan akan memacu mahasiswa untuk berkarya lebih baik. Mahasiswa mengerti dan memahami bagaimana gagasan dan kreativitas itu bisa diimplementasikan dalam proses berkarya.

Bab 2 Konsep Dasar Seni rupa sebagai awal pemahaman dan keberangkatan dalam berkarya seni lukis dengan menjelaskan masalah elemen seni rupa berkaitan dengan konsep berkarya. Mempergunakan teori seni rupa untuk dikuasai sebagai materi dalam membuat karya lukisan.

Bahwa elemen seni rupa bukan sebagai bentuk saja, tetapi bagaimana dengan mengerti dan memahami. Seorang pelukis 
akan mampu mengolah elemen seni rupa menjadi karya seni lukis bermakna. Dengan mempergunakan metodologi semiotik dan interpretasi.

Menguasai elemen seni rupa dengan sendirinya menguasai teknik seni lukis. Karena sebagian dari materi seni lukis, dari dasar senirupa yang dikuasai. Elemen seni rupa menjadi media untuk mentransformasikan gagasan dan kreativitas. Kemampuan melukis itu berbasis realitas sosial budaya sebagai bagian dari dirinya yang akan menstimulasi di dalam berkarya seni lukis.

Karya lukisan sebagai hasil dari representasi internalisasi seorang pelukis. Pengalaman menjadi kesadaran untuk mengungkapan realitas sosial budaya di dalam kehidupan masyarakatnya. Sebagai bentuk kreativitas seorang pelukis dalam melihat dan menangkap kehidupan realitas sosial budaya yang ada. Kemampuan menguasai teori dan konsep dasar seni rupa yang tepat.

Bab 3 Konsep Realitas Sosial Budaya, menjelaskan seni sebagai bagian dari kehidupan realitas sosial budaya. Manusia yang selalu memberikan dimensi yang lebih luas, dan memberikan pemahaman yang lebih baik. Bahwa berkesenian bukan saja pada masalah seni saja, tapi bagaimana karya seni itu mempunyai kontribusi pada masalah hidup dan kehidupan masyarakat.

Sebagai sebuah kesadaran di dalam melihat kehidupan, dan permasalahan hidup. Karena seni itu memang sudah menjadi fitrah dan jati diri manusia yang selalu menyukai keindahan. Keindahan adalah manifestasi nilai hakiki dari Sang Pencipta. Sebagai awal dari pintu gerbang kebaikan dan kerendahan hati seorang manusia.

Karena Allah Maha indah dan menyukai keindahan. Di mana alam semesta diciptakan dengan penuh keindahan dan manusia diciptakan dengan keindahan bentuk proporsi tubuh yang baik dan jiwa yang mengkokohkan. Keindahan itu memang 
menjadi sebuah realitas sosial kehidupan yang ada sebagai sebuah kebenaran. Semua itu selalu ditemui dalam kehidupan masyarakat, di mana manusia berada dalam kehidupannya seharihari.

Bab 4 Makna Alam Benda, Figur dan Lingkungan Realitas Sosial Budaya, sebagai sebuah tema melukisnya. Bagaimana tema dimaknai sebagai gagasan kreativitas dan kemampuan teknik berkarya serta keindahan dari karya seni lukis.

Bahwa seorang pelukis memang harus fokus dalam membuat seni lukis, sehingga memberikan kemampuan untuk membuat karya seni lukis yang maksimal. Di mana makna seni lukis menjadi kesadaran dalam pemahaman terhadap realitas sosial budaya sebagai nilai keindahan dengan lebih berarti.

Proses elaborasi menjadi bagian dari berkarya seni lukis agar mempunyai makna. Sebagai sebuah tanda dan sistem tanda dalam karya lukisan. Sedang petandanya adalah seorang pelukis yang lebih dalam bagi seorang pelukis dan masyarakatnya.

Karya lukisannya bukan hanya sebuah lukisan saja, tapi perspektif seorang pelukis dalam melihat sebuah permasalahan realitas sosial budaya. Sebuah hubungan yang berkembang di dalam kehidupan masyarakatnya. Sebagai sebuah keindahan karya seni lukis yang mempunyai nilai dan makna sebagai sebuah karya.

Ketika masyarakatnya mengapresiasi karya seni lukis dalam kehidupan realitas sosial budaya. Memberikan dimensi kehidupan dan pencerahan bagi kehidupan masyarakat dan pelukisnya. Dengan karya seni lukis itu seorang pelukis bisa mengelaborasi menjadi karya seni yang lebih luas. Menjadi visioner dalam mengeksplorasi gagasan dan media, yang ada di dalam kehidupan masyarakatnya.

Bab 5 Teknik Sapuan Kasar, Halus dan Ekspresif sebagai sapuan kuas akan menjadi teknik dan media yang menyalurkan 
kekuatan ekspresi seorang pelukis untuk menjelajah warna di kanvas. Untuk menemukan sesuatu yang baru dalam hidupnya. Sapuan sebagai sebuah penanda, sedang seorang pelukis adalah sebagai pemberi tanda dalam sistem tanda. Untuk menunjukan bahwa sapuan kasar, halus dan ekspresi bukan masalah teknis, meski mempergunakan teknik.

Bagi seorang pelukis kuas dan cat menjadi alat tercinta. Apa bila seorang pelukis menggunakannya semakin baik dan menemukan apa yang menjadi keinginannya. Ketika seorang pelukis melukis, akan menjadi semakin terbiasa dengan cara goreskan dengan sapuan kuas mampu menangani cat, dan apa yang bisa mereka capai sebagai seorang pelukis.

Tak lama kemudian kuas akan menjadi bagian dari pelukis. Karena mampu membawa pengalaman, perasaan dan ide serta gagasan lukisan itu.

Dengan langkah yang lazim dilakukan secara intuitif, akan mampu mengetahui bagaimana maneuver dalam bidang kanvas. Memberikan warna dan ekspresi yang menjelajahi bidang kanvas, menjadi sebuah representasi pengalaman seorang pelukis dalam kehidupannya.

Bab 6 Melukis Dengan Berbagai Gaya Lukisan memberikan kekayaan dan penguasaan teknik dalam melukis. Sebuah perjalan yang lazim pada seorang pelukis. Untuk mengetahui posisi dalam membuat lukisan, bisa juga menjadi representasi dari karakter seorang pelukisnya. Sebagai sebuah gambaran dari karya seni lukis yang mempunyai keaneka ragamaan gaya lukisan.

Meskipun bukan sebagai upaya mencari dan berhenti pada satu tahapan atau gaya. Penguasaan teknik seni lukis mampu memberikan pemahaman yang lebih luas dan mendalam sehingga memberikan makna dalam karya lukisan. Untuk memberikan kemungkinan berkarya menemukan karakter dan identitas diri dalam berkarya seni lukis. 
Membuat karya seni lukis bagian dari internalisasi kesadaran, untuk bisa membangun realitas sosial budaya dalam keindahan karya seni lukisnya. Memberikan pembelajaran bahwa melukis bukan permasalahan bentuk dan teknik dalam melukis, akan tetapi juga masalah keindahan dan kebaikan dalam kehidupan manusia.

Karya lukis adalah proses transformasi bentuk, gagasan, pengetahuan dan kemampuan teknik serta keindahan melukis. Dari interpretasi dan semiotika yang dipresentasikan sebagai karya lukisannya. Tapi bagaimana berkarya seni lukis itu bisa melahirkan gaya lukisan yang sesuai dengan apa yang menjadi permasalahan yang digagasnya.

Bab 7 Melukis Dengan Teknik Dasar Yang Sebenarnya Diatas Berbagai Media. Sebagai bentuk memahami dan menguasai teknik lukis menjadi satu kesatuan dalam berkarya, di mana seorang pelukis mampu membuat karya seni lukis yang baik, dan menguasai pengetahuan teknik apa yang dia kerjakan. Dengan demikian seorang pelukis sebagai seniman akan bisa mengembangkan kemampuan teknik melukis menjadi sesuatu yang baru dalam melukis.

Teknik dasar adalah kemurnian seni lukis yang dikuasai dalam dua dimensi. Karena seni lukis bisa berkembangkan pada karya seni lukis yang lebih tiga dimensi, mix media dan multi media. Sebagai sebuah dasar melukis yang bisa dikembangkan dan diimplementasikan pada bidang lain. Melukis teknik dasar sebagai inti dari pengembangan seni pada umumnya.

Kemampuan mengolah media berkarya seni yang ada di dalam kehidupan masyarakat. Apa lagi yang berkaitan pemberdayaan masyarakat terhadap barang tidak terpakai, untuk dikelola menjadi sebuah karya seni. Sebagai found object dalam gagasan berkarya seni lukis bagian dari kreativitas berkarya. Menjadikan barang bekas yang didaur ulang sebagai karya seni rupa yang 
mempunyai nilai keindahan. Dengan keindahan itu akan memperkaya kehidupan masyarakat di dalam melihat kehidupan dan perkembangan di masyarakat.

Semua itu hubungan antara karya seni lukis dengan kesadaran mahasiswa atau seorang pelukis melihat yang ada kaitan dengan barang yang tidak terpakai sebagai kepedulian terhadap lingkungan hidup. Sebagai salah satu seni dalam melebur dengan permasalahan yang ada dimasyarakat. Membuat masyarakat mempunyai kemampuan di dalam menata lingkungan sosialnya dengan baik.

Bab 8 Melukis Dengan Interpretasi Sesuai Tema Alam Benda, Figur dan Lingkungan Realitas Sosial Budaya. Pembelajaran ini lebih melihat permasalahan menjadi lebih luas berkaitan dengan seni lukis. Dalam proses pembuatan seni lukis dengan metode interpretasi tema. Membuat karya lukisan sebagai semiotika menjadi tahapan yang telah mencapai konsep gagasan. Interpretasi menjadi apa yang dilakukan dalam berkarya seni lukis.

Berkaitan dengan masalah realitas sosial budaya karya seni lukis, akan memberikan kemungkinan pada pemahaman terhadap kesadaran, seorang pelukis. Dalam melihat karya seni lukis, sebagai keindahan dan kekuatan dalam menangkapnya.

Untuk itu perlu dilihat sejauh mana karya seni lukis itu mempunyai keterkaitan dengan karya seni lukis. Gagasan dan konsep dengan semiotika dan interpretasi, yang menjadi tugas dalam pembelajaran seni lukis. Bahwa karya seni lukis terberdiri sendiri sebagai nilai keindahan, tetapi juga mempunyai nilai pada setiap orang. Baik sebagai seorang pelukis maupun masyarakatnya yang melihat karya lukisan.

Karya lukisan bukan memperlihatkan bentuk atau obyek yang ditangkap sebagai materi, tetapi juga sebagai makna yang dapat diperkaya dan memperkarya khazanah dan keindahan jiwa 
Membuat dirinya menjadi seorang bernilai yang tumbuh berkembang untuk menjadi lebih baik dan lebih baik. Sebagai sebuah kesadaran mengembangkan diri di dalam realitas sosial budaya kehidupannya.

Bab 11 Mempresentasikan Hasil Karya Lukisan Berbasis Realitas Sosial Budaya di dalam berkarya seni lukis dengan memberikan konstruksi gagasan dan kreativitas dalam berkarya, berkaitan dengan teknik yang berbasis realitas sosial budaya.

Seni lukis juga sebagai ekspresi seorang pelukis mempunyai muatan. Disadari maupun tidak mencerminkan kehidupan masyarakat. Realitas sosial budaya masyarakat itu yang memberikan warna yang direpresentasikan pada sebuah karya seni lukis.

Dengan demikian seni lukis bukan hanya sebuah bentuk keindahan saja, namun juga menjadi keindahan hidup dalam perkembangan masyarakatnya. Sebagai sebuah nilai yang berkaitan dengan kaidah norma sebagai sebuah tradisi masyarakat yang mempunyai berbudi luhur sebagai sikap dari masyarakatnya.

Realitas sosial budaya lebih diartikan sebagai suasana yang membangun dan menumbuhkan karakter seorang pelukis. Realitas sosial budaya terdapat dalam sebuah tradisi yang ada di dalam kehidupan masyarakat. Bisa jadi sebuah realitas sosial budaya yang berkembang di dalam kehidupan masyarakat. Berkaitan dengan nilai tradisi yang ada di dalam masyarakat sebagai kaidah dan pemahamannya.

Walaupun disisi lain ada satu perkembangan yang ada di dalam kehidupan masyarakat. Pengaruh dari perkembangan ilmu pengetahuan, teknologi dan informasi yang bisa merubah masyarakatnya. Seni lukis akan mengikuti perkembangan dengan dasar seni lukis sebagai ekspresi dalam arti luas di dalam berkarya. Ekspresi lebih kaya dan indah lagi, karena pemahaman dan 
pegetahuan yang berkembangan sesuai dengan perkembang-an manusianya sebagai seorang pelukis.

Bahwa karya lukisan merupakan sebagai bentuk karya yang dinamis sebagai konsep berkesenian, meskipun bentuk dan media seni lukis berkembangan mengikuti perkembangan manusianya. Karena seni lukis itu sejalan dengan perkembangan realitas sosial budaya masyarakatnya. Dalam hal ini seorang pelukis yang setiap zaman akan berbeda dalam segi pemikiran, pandangan, pengalaman dan rasa berkeseniannya, serta material dan medianya.

Perkembangan itu juga mempengaruhi cara membuat karya lukisan bagi seorang pelukis. Di mana karya lukisan bukan saja dililhat sebagai ungkapan spiritual keagamaan sampai pada konsep gagasan seni lukis. Untuk selalu bersinggungan dengan ilmu pengetahuan, lintas disiplin seni lainnya (interdisipliner) serta lintas diluar bidang seni seperti ilmu pengetahuan alam, agama dan sebagainya (transdisipler) dalam berkarya.

Membuat lukisan mengalami pemaknaan tema, bentuk dan elemen seni rupa, serta keindahan yang menjadi satu kesatuannya. Lukisan itu dapat dilihat, baik dalam cara menyikapi perkembangan ilmu pengetahuan, teknologi dan informasi. Maupun bagaimana mengolah gagasan kreativitas keindahan dalam proses berkarya seni lukis. Dengan kemampuan teknik yang juga mengikuti sebuah perkembangan dari realitas sosial budaya masyarakatnya.

Mempelajari seni lukis tidak hanya dengan mengandalkan kemampuan teknik dan bentuk yang indah dalam sebuah karya seni lukis saja. Tetapi bagaimana karya lukisan itu berkembang dan mengalami transformasi konsep gagasan seni lukis. Transformasi komunikasi sebagai bentuk tanda dalam karya seni lukis. Membuat karya seni lukis itu mengalami pemaknaan di bentuk dan keindahan dari segala macam aspek pemahaman realitas sosial. 


\section{Pembelajaran Seni Lukis}

Pembelajaran seni lukis sebagai sebuah konsep yang berangkat dari gagasan dan kreativitas pelukis. Dengan cara menjelaskan sebuah karya seni berangkat dari sebuah tema, berkaitan dengan realitas sosial budaya. Mempergunakan metodologi dan riset di dalam berkarya sebagai tahapan prosedural seorang pelukis. Pembelajaran seni lukis ini menjadi perkembangan dan kemajuan dari realitas sosial budaya.

Bahwa sebuah tema dalam konsep gagasan dan kreativitas seorang pelukis berkembang menjadi pemahaman realitas sosial budaya yang lebih indah dan bermakna. Sebagai sebuah kesadaran dalam melihat permasalahan kesenian secara lebih menyeluruh, tanpa mengabaikan kompetensi sebagai seorang pelukis.

Untuk bisa melihat realitas sosial budaya sebagai bagian dari seni lukis. Bahwa manusia di dalam keberadaannya, tidak tunggal atau sendiri sebagai seorang pelukis, tapi juga bagian dari realitas sosial masyarakat. Membuat masyarakat berada dalam pemahaman keindahan dan kebaikan dalam nilai karya lukisan yang luas dan menjadi lebih kaya.

Membuat lukisan itu mengembangkan nilai dan keindahan masyarakatnya, sehingga melahirkan kesadaran berkesenian yang lebih luas. Karya lukisan itu menjadi bagian dari kehidupan manusia yang mempunyai peran dalam mengembangkan keindahan dan kebaikan sosial masyarakatnya.

Seni lukis bukan hanya berkaitan dengan teknik dan ekspresi estetis seorang pelukis saja, akan tetapi realitas sosial budaya masyarakat yang memahami tradisi budaya dan perkembangan budaya sebagai dinamika kehidupan masyarakatnya. Sebuah lukisan bukan karya yang tidak ada kaitannya dengan masyaraka yang hanya dipajang pada tempat tertentu dan hanya orang tertentu yang menyaksikan. 
Karya seni lukis memang dalam mengasah keindahan jiwa, rasa dan emosi menjadi lebih baik. Membuat karya seni lukis mempunyai peran dalam kehidupan masyarakat. Karya lukisan dapat melihat segala permasalahan realitas sosial budaya, lebih luas dan persuasif. Sebagai suatu sentuhan dari realitas sosial budaya kehidupan agar bisa memberikan perspektif yang berbeda, sebagai refleksi diri seorang pelukis dan masyarakatnya.

Lukisan melihat permasalahan realitas sosial budaya lebih beragam, tanpa ada satu keterpaksaan masyarakat melihat dan memahaminnya. Masyarakat adalah sekumpulan orang yang mempunyai nilai hidup, di mana seni dan seni lukis tumbuh dan berkembang sesuai dengan alamnya. Menjadi keindahan hidup manusia lebih mempunyai makna kebaikan. Meskipun harus diupayakan dalam mewujudkan masyarakat yang berbudaya.

Seni lukis mampu melihat permasalahan realitas sosial budaya itu menjadi lebih jelas, karena pelukis mampu menghadir tema menjadi sesuatu yang baru dan memberikan pencerahan pada diri maupun orang lain. Menjadi tahapan dalam membangun diri setiap orang menjadi lebih baik, berkaitan dengan nilai etika, moral dan agama.

Gagasan dan kreativitas di dalam berkarya seni lukis Berbasis Realitas Sosial Budaya dengan model pembelajaran konstruksitivis humanistis, mahasiswa sebagai seorang pelukis memahami dengan penjelasan dari tema permasalahan realitas sosial budaya yang berkaitan dengan pegalaman hidupnya. Untuk bisa mengolahnya menjadi sebuah kesadaran dalam berkesenian.

Untuk bisa dikonstruksikan dan dimaknai dalam sebuah karya seni lukis yang dibuatnya. Sedangkan adanya pertanyaan, bisa memperkuat apa yang menjadi permasalahan yang mempunyai kesamaan atau kemiripan di dalam berkarya seni lukis. Dengan demikian menjadi kesadaran baru bagi dirinya. Karya seni 
bisa memberikan kontribusi pada sebuah nilai karya seni untuk bisa diapresiasi pada masyarakat.

Bentuk lukisan terdiri dari tiga elemen yang meliputi bahan dasar terdiri dari kerangka kayu atau span ram, dan bahan sehingga menjadi kanvas setelah dilapis pigmen dan perekat disebut dengan "priming" yang dicampur air untuk menutup pori2 kain, dan mampu menyerap warna dengan baik. Berikutnya cat dan kuas atau pisau palet untuk mengungkapkan gagasan berkarya.

Berkarya seni lukis bukan sebagai sesuatu keterampilan, tapi memang sebagai sebuah kebutuhan dalam realita sosial budaya. Untuk bisa berperan serta dalam perkembangan kehidupan berbangsa dan bernegara dari aspek kehidupan sosial budaya, untuk selalu dikembangkan. Membuat karya seni lukis menjadi lebih berarti bagi kehidupan realita sosial budaya dalam arti sebenarnya. 
Seni Lukis, Kansep dan Metade 


\section{BAB I \\ GAGASAN DAN KREATIFITAS BERKARYA SENI LUKIS}

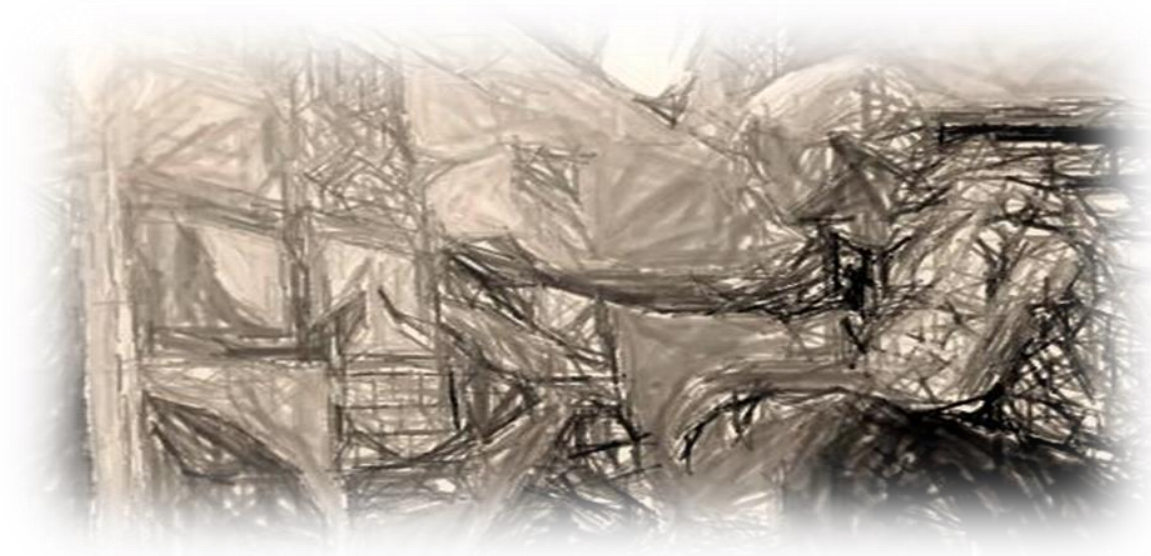

Tebuah gagasan dan kreativitas dalam karya lukisan sebagai ungkapan seorang pelukis untuk menangkap realitas obyek, figur dan pemandangan alam. Didasarkan pada ketertarikan pada keindahan, dan ingin sedikit berbeda, serta dorong perasaan yang membuatnya tertarik pada sesuatu, untuk melukis.

Namun dalam perkembangannya atau setelah lama menggeluti seni lukis, ternyata masih ada yang perlu dipahami dan disadari di dalam melukis. Karya seni lukis bukan hanya melukis obyek yang dilihat. Tetapi di dalam karya lukisan itu ada kebaikan, kebenaran dan keinginan yang bermakna.

Peirce memandang bahwa proses pemaknaan (Signifikasi) menjadi penting karena manusia memberikan makna pada realitas yang ditemuinya. Dengan demikian keindahan seni lukis mempunyai keterkaitan yang erat dengan realitas sosial budaya. 
Disini Peirce memaknai semiotika sebagai studi tentang tanda dan segala yang berhubungan dengan tanda, cara berfungsi (sintaktik semiotik) dan hubungan antar tanda (semantik semiotik), serta mengkaji pengirim dan penerimanya oleh mereka yang mengunakan tanda (pragmatik semiotik) (Panuti dan va Zoet, 1996:5-6).

Karya seni lukis sebagai sebuah tanda yang melekat pada lukisan dan realitas sosial budaya. Tanda sebagai satu kesatuan yang ada di dalam karya seni lukis, karena bersifat ekspresif. Lukisan sebagai bentuk yang ada dalam realitas bidang kanvas yang dilukiskan oleh seorang pelukis. Namun bentuk yang dilukis dalam karya seni lukis itu menjadi sebuah tanda ungkapan seorang pelukis, yang bersifat ekspresif.

Sebab disana bisa dilihat sebuah pengalaman realitas sosial budaya yang melekat pada pelukisnya. Begitu juga dengan bertambahnya pemahaman dan pengetahuan seni bukan hanya sebagai pengalaman, tapi disitu ada sebuah gagasan dan kreativitas seorang pelukis. Baik dilihat dari bentuk, warna, garis dan sapuan, komposisi, tekstur dan bidang yang dipergunakannya menyiratkan sebuah gagasan, seorang pelukis yang ingin diungkapkan.

Membuat seni lukis bukan sebagai ekspresi dibidang dasar, dua dimensi. Tapi menjadi sebuah pengetahuan seni dalam arti tekstual dan konstektual. Begitu juga sebagai pengetahuan substansial maupun filosofis dari karya seni lukis yang dibuat. Lukisan membaca bentuk dan nilai dari sebuah realitas sosial budaya dari masyarakat di mana seni lukis itu dibuatnya.

Untuk itu dalam membicarakan seni lukis yang berkaitan dengan gagasan dan kreativitas berkarya tidak lepas dari kesadaran seorang pelukis dalam memulai keinginannya melukis. Gagasanlah yang memulai dan mendorong untuk membuat lukisan. Kemudian strutural lain yang akan mengikuti dari proses pembuatan lukisan. 
Misalnya Vincent van Gogh melukis "Slaapkamer te Arles" dengan sapuan kuas yang kasar, ekspresif. Lukisan "Slaapkamer te Arles" dengan sapuan kuas yang kasar, ekspresif menjadi sebuah tanda dari seorang pelukis Vincent van Gogh. Bahwa Vincent van Gogh bukan membuat lukisan "Slaapkamer te Arles" tapi Vincent van Gogh sedang mengekspresikan gagasan dirinya melalui "Slaapkamer te Arles"

Melukis sebagai sebuah tanda seorang pelukis yang mempunyai hubungan emosional, kedekatan atau keterkaitan dengan realitas sosial budaya masyarakat. Masing-masing memberikan makna, realitas sosial budaya karena kedekataannya, sehingga dapat memberikan makna pada seorang pelukis.

Seorang pelukis, melukiskan realitas sosial budaya menjadi sebuah makna, dari hasil makna realitas sosial budaya masyarakat yang ditangkap, dipersepsikan dan dirasakan sebagai pengalaman seni.

Charles Sander Peirce sampai pada keyakinan bahwa manusia berpikir dalam tanda. Maka demikianlah ia sempat menciptakan ilmu tanda, yaitu semiotika, baginya sinonim dengan "logika". Menurut Peirce, logika mengakar pada sesuatu yang menyangkut masyarakat (Aart van Zoest, 1993; 10).

Dalam pandangan Peirce, tanda disebut dengan represent, yaitu sesuatu yang mewakili sesuatu lain yang diacunya. Suatu benda, peristiwa, struktur, suara, kesepian atau apa pun mungkin merupakan tanda atau menjadi tanda, dengan syarat mengacu pada sesuatu yang lain. Sesuatu yang diacunya disebut obyek ( Dadan Rusmana, 2014: 40).

Membuat lukisan sebagai sebuah interprestasi realitas sosial budaya dalam bidang kanvas yang menjadi sebuah realitas baru dalam gagasan seorang pelukis. Karya lukisan menjadi bentuk yang mempunyai muatan gagasan dan rasa seorang pelukis. 
Jadi, Interpretasi ialah tanda yang berkembang dari tanda yang telah lebih dahulu ada dalam benak orang yang menginterpretasikan realitas sosial budaya dalam lukisan.

Membuat karya lukisan dapat memberikan pengetahuan, sebagai suatu realitas sosial budaya. Gagasan melukis menjadi sebuah proses karya seni lukis. Kemampuan teknis dalam merasakan dan sensitivitas rasa, dalam mengolah serta membuatnya.

Gagasan menjadi proses bepikir yang intinya mengingat kembali dalam membangun hubungan-hubungan sehingga benda atau kejadian yang ingin kita kenali berada kembali dalam suatu konstelasi dunia yang ada di dalam benak kita.

Mengingat kembali adalah membiarkan daya ingat kita akan benda atau suatu kejadian dalam suatu "permainan antara" yang memperlihatkan dirinya sendiri. Segala seuatu didalam kepala kita bermain seperti adanya. (Bagoes 2000: hal 111)

Menurut Stephen Spender gagasan bagaikan awan suram yang saya rasakan harus dipadatkan menjadi hujan kata-kata atau bentuk dan sapuan (karya seni lukis). Sedang Afled North Whitehead berbicara tentang keadaan ketegangan kekacau balau yang mengandung daya khayal yang mendahului perumusan induktif yang berhasil.

Untuk itu berpikir dan berbuat dalam melakukan sesuatu merupakan satu kesatuan di dalam membuat karya seni. Dengan demikian munculnya idenya yang selalu mendorong untuk berkarya atau melakukan sesuatu yang lebih baik.

Selain kegiatan berpikir yang bisa memunculkan gagasan di dalam membuat karya seni. Ada yang tidak kalah pentingnya adalah kepekaan dan berempati yang dimunculkan oleh perasaan yang mendalam sehingga membuka perspektif dari terciptanya karya seni lukis. Perasaan yang mendalam adalah sebuah intuisi yang kuat di 
dalam melihat getaran kehidupan yang lebih luas dan menyeluruh. Untuk mendorong sebuah ide dan gagasan untuk bisa merealisasikan lahirnya sebuah karya seni lukis.

Proses berpikir merupakan proses dimana sesuatu yang dipikirkan akan menghasilkan sebuah gagasan. Baik itu berpikir secara diskriptif yang menjadi pola berpikir rasional dengan mempergunakan logika. Kemudian hanya memberikan beberapa kemungkinan dari sebuah susunan yang didapat dari gagasan yang begitu banyak.

Konsep gagasan itu lahir dari pengalaman hidup yang terakumulasi dan sudah mengalami proses internalisasi dan analisis berdasarkan pengetahuan yang dimilikinya. Kemampuan teknik berkarya juga dapat mengantarkan pada bentuk konsep gagasan berkarya seni lukis, mendorong untuk membuat karya lukisan.

Hanya saja bentuk karya seni lukis yang akan dibuatkan mengalami akumulasi yang didasarkan pada ketiga aspek tadi; pengalaman, pengetahuan dan kemampuan teknik. Proses itu merepresentasikan karya yang berangkat dari empat bentuk dalam sebuah karya lukisan.

Sering juga terjadi pada seorang pelukis tidak mengalami keadaan siap dalam dirinya untuk melakukan sesuatu yang baru, kaitan dengan berkarya seni lukis. Maupun dengan keadaan perasaan yang samar-samar mengenai sesuatu gagasan mengalami sesuatu yang khusus tetapi belum terasa jelas.

Namum hal itu kadang muncul secara spontas, dengan tibatiba, tanpa ada satu gejala dan pendahuluan yang pada seorang pelukis. Kadang-kadang secara sekilas begitu saja memperlihatkan sebuah karya lukisan secara keseluruhan terungkap.

Dalam membuat karya lukisan, bisa saja berjalan dengan begitu saja, walaupun gagasan hanya sepintas belum lengkap dan memerlukan penyempurnaan. Namun yang terjadi karya lukisan itu 
ketika telah hampir selesai, dengan sendiri akan disempurna sejalan dengan proses berkarya lukis.

Hal ini memperlihatkan gagasan seni lukis pada seorang pelukis bukan bergerak dalam satu tataran berpikir atau berimajinasi dalam mengenali tema lukisan yang ada dalam realitas sosial budaya. Tetapi lebih jauh sebagai pengalaman yang dialami seorang pelukis, sehingga terkadang susah untuk diformulasikan, kadang muncul dengan sendiri dalam proses berkarya, sebagai sebuah perasaan yang begitu saja bergerak.

Sedangkan kemampuan teknik dalam berkarya sebagai kemampuan motori, ketrampilan seorang pelukis. Membuat karya lukisan yang diolah dalam mengekspresikan diri membawa pada keasikan dirinya. Keindahan karya seni lukis membuat seorang pelukis menjalani hidupnya lebih pada kesadaran hidup.

Gagasan mempunyai eleman seni rupa yang dapat memberikan bentuk dan teknis dari keindahan, namun tidak bisa dihindari oleh seorang pelukis mengalami dan menghadapi permasalahan dalam berkarya. Ketika seorang pelukis dan lukisannya dalam hambatan, ketika konsep gagasan seni lukis itu menguat di dalam dirinya. Untuk berupaya mengatasi dengan membuat karya lukisan yang dicoba di kelola. Proses pengembangan diri, untuk melihat dengan kreativitas seorang pelukis. 
Dewey berpikir, bahwa gagasan supranatural lebih merupakan fungsi dari psikologi yang menghasilkan karya seni dari pada ilmu pengetahuan atau filsafat. Hal ini dapat dilihat oleh prosesi khusyu dan fenomena seni lainnya di gereja-gereja. Keats terkenal menulis "Kecantikan adalah kebenaran, kebenaran kecantikan itu saja kamu tahu di bumi, dan semua kamu perlu tahu."

Sekarang bagaimana gagasan itu bisa dirasakan dan diketahui bahwa kita itu sudah mempunyai gagasan. Dengan kita menyadari bahwa setiap manusia mempunyai gagasan Kesadaran tentang itu akan memberikan kemudahan dalam melihat peta kehidupan yang dijalaninya.

Pengalaman pemikiran memuaskan kita secara emosional karena sudah terintegrasi secara internal, dan belum ada aktivitas intelektual yang terintegrasi dengan cara ini kecuali memiliki kualitas estetika. Jadi, untuk Dewey, tidak ada pemisahan yang jelas antara estetika dan intelektual.

Karena masing-masing orang akan mempergunakan gagasan itu kapan saja bila dibutuhkan, gagasan itu akan muncul dan datang membantu untuk mengatasi permasalahan. Sejalan dengan kehidupan itu berjalan.

Begitu juga kalau ada keinginan memenuhi kebutuhan hidup yang mendorong kita untuk melakukan sesuatu atau membuat sesuatu, untuk menciptakan tentang apa yang menjadi gagasan dan pemikiran.

Dalam bentuk menggambar sketsa, setiap bentuk dengan garis-garis saja dengan singkat. Untuk itu kita bisa melihat dari berbagai macam jenis-jenis sketsa antara lain.

Gambar sebagai garis besar yaitu sketsa yang membuat garis-garis bentuk sederhana tanpa rincian dan tidak selesai.

Sketsa cepat yaitu sketsa yang menggunakan beberapa garis saja untuk menampilkan citra suatu sketsa yang sudah selesai. 
Studi citra yaitu sketsa yang berupa coretan dengan cepat dan kurang terperinci hanya menunjukan bentuk global

Untuk itu perlu dijelaskan elemen seni lukis itu merepresentasikan ide dan gagasan, yang telah dikelola dalam dirinya, sehingga mengalami internalisasi, kemudian menjadi spirit seni. Sebagai rangkaian yang menjadi satu kesatuan di dalam proses melukis. Media, baik itu pensil, pena sebagai sebuah sketsa maupun kanvas dengan cat minyak atau cat akrilik.

Kemudian teknik itu untuk mewujudkan itu semua menjadi sebuah bentuk lukisan yang mempunyai makna. Untuk bisa diapresiasi pada orang lain sebagai sebuah ekspresinya. Itu apa yang dimanakan seni lukis bukan hanya mempunyai nilai keindahan seni, teknik, tetapi juga disitu gagasan yang sudah mengalami internalisasi menjadi sebagai sebuah spirit dari seni lukis.

Dengan memberikan jalan keluar dengan berbagai macam alternatif dari sekian banyaknya kemungkinan gagasan. Itulah gagasan dan kreativitas yang selalu lahir dimana-mana, kapan saja, dimana kita membutuhkan.

Karena mekanisme rohani dan jasmani bekerja dengan baik, mengikuti kehidupan ini, di mana kehidupan yang diciptakan Allah agar manusia selalu berpikir dan bersyukur. Sebagai manifestasi kesadaran tentang nilai dan arti sebuah gagasan.

Gagasan itu lahir dari proses berpikir tentang sesuatu yang dipikirkan secara terstruktur, dimana apa yang sedang dipikirkan itu dikumpulkan menjadi sebuah susunan yang menghasilkan bentuk baru atau menjadi karya seni. 
Realitas sosial budaya mampu merangsang proses perasaan dan pikiran untuk melahirkan gagasan dan kreativitas yang selama ini tidak pernah terpikirkan oleh kita. Tanpa harus memikirkan media apa yang dipergunakan dalam berkarya. Karena itu dengan sendirinya akan mengikutinya.

Hal itu juga sering dilakukan oleh pelukis Affandi bersama teman-temannya berjalan-jalan ke pasar, gunung dan kampung. Menyelusuri realitas sosial budaya dalam gagasan dan fakta kesehariannya. Mendorong untuk melakukan aktifitas melukis secara berkala.

Ketika di dalam berkarya itulah, gagasan dan kreativitas menjadi dasarnya yang sangat mudah. Namun hal itu tergantung dari kesiapan kita di dalam menyambut lahirnya gagasan dan kreativitas tersebut. Dengan ada gagasan dan kreativitas setiap saat menjadi salah satu pemicu di dalam berkarya secara lebih baik, sesuai dengan media yang kita pergunakan.

Gagasan dalam melukis tidak lepas dari pengalaman, pengamatan, pengetahuan yang di internalisasikan dalam realitas sosial budaya kehidupan, sebagai sebuah riset dalam membuat karya. Dengan membuat tahapan dan prosedural dalam yang dibuat untuk dapat mengetahui apa yang terjadi dalam berkarya. Dengan demikian akan dapat diatasi sesuai dengan permasalahan yang dihadapi atau hambatan di dalam berkarya seni lukis.

\section{Proses Kreatif}

Dalam membuat karya seni lukis adalah sebuah proses kreatif yang dilakukan secara "sistematis" untuk mempermudah dan mempercepat pemahaman bagi seorang pelukis didalam berkarya dengan berbagai macam media. Sebagai kerangka berpikir seorang pelukis, sehingga bisa memahami dirinya sendiri untuk bisa 
melangkah di dalam membuat karya seni lukis secara benar dan secara berkesinambungan.

Guilford sendiri menemukan yang menjadi faktor seseorang mempunyai kemampuan berpikir kreatif, yaitu :

Pertama, kelancaran berpikir (fluency of thinking), yaitu kemampuan untuk menghasilkan banyak ide yang keluar dari pemikiran seseorang secara cepat. Dalam kelancaran berpikir yang ditekankan adalah kuantitas, bukan kualitas.

Kedua, keluwesan (flexibility), yaitu kemampuan untuk memproduksi sejumlah ide, jawaban-jawaban atau pertanyaanpertanyaan yang bervariasi, dapat melihat suatu masalah dari sudut pandang berbeda-beda, mencari alternatif atau arah yang berbedabeda, dan mampu menggunakan bermacam-macam pendekatan atau cara pemikiran.

Orang yang kreatif adalah orang luwes dalam berpikir. Mereka dengan mudah dapat meninggalkan cara berpikir lama dan menggantikan dengan cara berpikir yang baru. Sebagai langkah yang harus dijalan dengan segala macam tantangan dan rintang yang menjadi motivasi untuk menghadapinya.

Ketiga, elaborasi (elaboration), yaitu kemampuan dalam mengembangkan gagasan dan menambah atau memperinci detildetil dari suatu obyek, gagasan atau situasi sehingga menjadi lebih menarik.

Keempat, keaslian (originality), yaitu kemampuan untuk mencetuskan gagasan unik (unusual) atau kemampuan untuk mencetuskan gagasan asli. 
mengalami perkembangan. Dengan landasan seni lukis, konsep kreatif dan pola pandang yang jauh kedepan dalam melihat realitas sosial budaya.

Hal itu bisa berkembang pada diri seorang pelukis maupun masyarakat sekitarnya, di mana seorang pelukis itu berada. Seperti seorang empu yang mempunyai kemampuan membuat keris, tetapi juga sebagai tokoh yang disegani di masyarakatnya. Untuk dimintain petuah atau nasihat-nasihatnya oleh masyarakatnya, tentang masalah kehidupan sehari-hari yang dihadapinya.

\section{Metodologi Kreatif}

Metodologi secara bahasa berasal dari bahasa yunani yaitu "methodos" dan "logos". Kata "logos" berarti ilmu atau bersifat yang ilmiah. Jadi metodologi adalah ilmu atau cara yang digunakan untuk memperoleh suatu kebenaran dengan menggunakan penelusuran dengan urutan atau tata cara tertentu sesuai dengan apa yang akan dikaji atau diteliti secara ilmiah.

Pengertian kreatif menurut kamus besar bahasa Indonesia adalah 1) memiliki daya cipta; memiliki kemampuan untuk menciptakan; 2) bersifat (mengandung) daya cipta: pekerjaan yang menghendaki kecerdasan dan imajinasi;

Baik itu berkarya dalam seni pertunjukan, senirupa, film dan televisi. Semua perlu adanya metodologi kreatif yang tepat untuk masing-masing media yang dipergunakan. Dan satu sama lain berbeda metodologinya, hal ini tergantung dari apa yang dia ingin garap.

Begitu juga dalam senirupa setiap karya berbeda, misalnya saja antara karya desain, kriya dan seni murni. Apa lagi dalam seni murni dimana ada seni lukis, patung dan seni grafis yang media satu sama lain berbeda, maka dengan begitu metodologi berkarya seni 
itu mampu penyerapan juga berbeda sesuai dengan bentuknya masing-masing.

Metodologi dan tahapan dilalui karya seni lukis adalah sebuah proses kreatif berbasis realitas sosial budaya. Sebagai sebuah tahapan yang memerlukan mekanisme proses yang saling merefleksikan disetiap tahapan. Bahwa pengalaman realitas sosial budaya sebagai bentuk persiapan dan kesadaran seorang pelukis dalam membuat karya. $\mathrm{Di}$ mana pengalaman mengalami internalisasi dalam masa tertentu, bergerak dalam pencetusan gagasan dan membuat karya seni lukis.

Untuk membuat karya seni lukis memang sudah mencapai tahap atau kadang memerlukan moment yang diperlukan dalam membuat karya. Pada tahapan itu seorang pelukis dengan sendiri akan membuat karya. Akan tetapi seorang pelukis dalam membuat karya seni lukis yang memerlukan berbagai persiapan dan kesadaran dalam membuat karya, agar tergambarkan, hal ini akan dipahami, sebagai berikut:

1. Pengalaman, Mengumpulkan informasi, berkonsentrasi, dan mengakrabkan diri sepenuhnya dengan semua aspek

2. Internalisasi, Merenung, membayangkan gagasan, memberi waktu bagi pikiran untuk beristirahat dan mengumpulkan energi.

3. Pencetus, pencerahan, saat nah, ini dia! Saat jawaban tiba-tiba muncul - sering terjadi saat kita sedang benar-benar santai dan melakukan hal yang lain, misalnya membuat sketsa, membaca buku, mendengar musik, melakukan aktifitas sehari-hari diluar berkarya seni lukis dan jalan-jalan.

4. Membuat karya seni lukis Menyelesaikan masalah praktis, berusaha memperoleh dukungan orang lain, menentukan berbagai sumber daya yang diperlukan. Untuk memperkuat sikap dan penyelesaikan karya. 
bahwa mereka bisa menjelaskan apa-apa, bahwa seni mereka turun ke atas mereka oleh inspirasi. Kami memiliki sebelum kita usia penciptaan sadar, dan semangat baru dalam lukisan akan bergandengan tangan dengan semangat pemikiran menuju era spiritualitas besar.

Cassandra B. Whyte menekankan pentingnya pengalaman artistik bagi mahasiswa untuk mendorong proses berpikir kreatif dan independen yang akan menjadi penting sepanjang hidup seseorang. Seni membantu mahasiswa dengan pemecahan masalah dan pengambilan keputusan dan pengalaman-pengalaman pengolahan bisa diadaptasi dalam situasi kehidupan secara umum.

Whyte menganjurkan termasuk dalam aspek pendidikan seni dengan lokus kontrol pengalaman konseling identifikasi untuk membantu mahasiswa pendidikan tinggi mengembangkan kepercayaan diri dalam masalah mereka yang unik kemampuan pemecahan di kelas dan di dalam hidup.

Dewey berpikir bahwa mereka yang menolak kesinambungan antara pengalaman sehari-hari dan seni rupa gagal untuk melihat materi yang dibutuhkan untuk mewujudkan cita-cita.

Alam adalah habitat manusia, dan budaya sebagai bagian bentuk bertahan, karena manusia menemukan dukungan untuk itu, di alam. Hasil budaya yang berkesinambungan, interaksi kumulatif dengan lingkungan. Manusia sangat merespon seni karena hubungannya dengan kedua pengalaman budaya dan alam.

Kreatif menjadi orang lebih terbuka terhadap permasalahan, mampu mengembangkan dirinya secara internal. Apa lagi kreatif sebagai wujud kesadaran pada nilai agama, dengan kemampuan spiritualitas ini seseorang sangat peduli terhadap masalah sosial.

Seni lukis menjadi sebuah perkembangan kreativitas dari seorang pelukis yang dimulai dengan gagasan dan konsep berkarya, sebagai pendorong dalam lahirnya proses kreatif dalam melukis. 
Kreativitas juga memperkuat pada tahapan di dalam membuat karya. Mampu melihat permasalahan dengan berbagai kemungkinan, sehingga proses berkarya seni lukis tidak terpaku pada bentuk, teknik atau tema.

Untuk itu seni lukis hasil dari kreativitas sebagai sebuah media yang kuat itu membangun kesadaran manusia. Kreativitas selalu mensimulasi dalam mempersepsikan diri terhadapan realitas kehidupan ini. Sebagai bentuk pernyataan diri manusia berada dalam realitas kehidupan yang bermakna.

\section{Belajar Melukis}

Banyak orang yang berminat dan ingin menekuni seni lukis belajar secara otodidak. Dengan penuh kesungguhan untuk melukis terus melukis dengan harapkan akan mahir dan menjadi seorang pelukis. Kemampuan melukis didasarkan latihan ketrampilan. Untuk bisa menggambarkan apa yang dirasakan dalam mempersepsikan realitas kehidupan sosial budaya dalam sebuah karya seni lukis.

Dunia seni lukis bagi kehidupan manusia mampu memberikan kebebasan untuk melukis realitas sosial budaya yang berkenan bagi dirinya, dengan sesuka hatinya. Sudah tentu akan membuat lukisan yang menggambil tema dan judul yang dekat dengan kehidupan masyarakat dan pengalaman dirinya.

Meskipun hanya sebagai sebuah tema dan judul melukis, namun dalam melukis lebih menekan pada lukisan yang terpola sesuai dengan apa yang dinginkan pengajarnya atau yang berkembangan pada umumnya, bersifat baku. Bukan melukis pada suatu tujuan yang ingin dicapai.

Dengan demikian proses pembelajaran dalam seni lukis menggulang lukisan dengan tema atau judul yang berbeda. Dengan demikian pola belajar melukis tidak mempunyai desain pembelajaran yang terstruktur. Tidak memakai prinsip instruksional. 
sebagai representasi dari seni lukis. Sebagai paduan antara pengetahuan seni, teknik dan pegalaman sebagai seorang pelukis yang berada dalam realitas sosial budaya.

Seperti apa yang dilakukan oleh seniman pada masalah lalu yang dikenal dengan Empu, seorang yang dianggap banyak menguasai ilmu tentang seni dan kehidupan. Membuat Empu itu mampu memberikan kontribusi nilai spiritual dan kearifan lokal. Sebagai seorang yang dihormat dan dihargai oleh kalangan masyarakatnya.

Di mana Empu di dalam berkarya bukan hanya pada pendekatan teknik dan media, tetapi harus dimulai dengan ritual tersendiri. Sebagai sebuah tahapan berkarya yang menjadi sebuah artikulasi dari budaya yang ditumbuh dalam berkesenian. Bahwa membuat sebuah karya bukan masalah kemampuan teknik sebagai ketrampilan. Tetapi kemampuan teknik yang lahir dari dalam diri, jiwa sebagai dorong untuk membuat karya. Jiwa seni itu lahir dari hasil olah jiwa dengan melakukan ritual, sebagai aspek kehidupan budaya masyarakatnya.

Agar berkarya itu memberikan kesempurnaan bentuk maupun jiwa. Sebagai wujud dari kepaduan antara bentuk dan spiritual, antara fisik dan metafisik. Membuat karya itu menjadi simbol budaya yang dipelihara sebagai bagian dari hidup dan kehidupan masyarakatnya.

Sebagai bentuk pembelajaran seni lukis, dalam membuat karya seni dengan pendekataan alamiah. Dari kepercayaan dan pengalaman yang dirasakan, ketika menemukan, pada saat membuat karya seni. Proses ini yang kemudian diulang-ulang dalam membuat karya seni lukis. Cara belajar seni lukis ini, yang menjadi realitas sosial budaya masyarakat.

Begitu juga dalam membuat karya seni lukis masih ada yang melakukan penghayataan dan internalisasi pengalaman, dengan 
cara puasa. Mengosongkan pikiran, agar jiwa dan rasa dapat merasakan apa yang terjadi dalam denyut pengalamannya.

Belajar melukis dalam aspek budaya mempunyai pendekatan yang berbeda. Melukis memang mempunyai mekanis gagasan bisa berangkat dari aspek meteri dan material. Begitu juga aspek pengalaman dari sebuah keinginan pada sebuah pandangan tertentu. Cara belajar yang berbeda dalam membuat karya seni lukis.

Dengan demikian cara melakukan proses berkarya juga berbeda. Ada dari formalisme seni lukis, dan ada dari segi rasa dan jiwa. Meskipun material menjadi satu dari seorang pelukis dalam masyarakatnya. Seperti ada lukisan beber, lukisan kamasan yang lahir dari sebuah kebudayaan masyarakatnya.

Seni dan estetika, menurut Dewey, merupakan upaya untuk menemukan cahaya dalam kegelapan besar. Seni menghimbau langsung ke akal dan imajinasi sensual, dan pengalaman estetika dan agama terjadi sebagai akibat dari energi dan bahan yang digunakan untuk memperluas dan mengintensifkan pengalaman hidup.

\section{Model Pembelajaran Seni Lukis}

Model pembelajaran diartikan sebagai prosedur sistematis dalam mengorganisasikan pengalaman belajar untuk mencapai tujuan belajar. Dapat juga diartikan suatu pendekatan yang digunakan dalam kegiatan pembelajaran.

Menurut Richard I Arends, model pembelajaran mengacu pada pendekatan yang akan digunakan, termasuk di dalamnya tujuan-tujuan pembelajaran, tahap-tahap kegiatan di dalam pembelajaran, lingkungan pembelajaran dan pengelolaan studio.

Model pembelajaran seni lukis lebih menekan hanya bagaimana melukis itu menjadi sebuah landasan karya seni yang 
mempunyai keindahan. Keindahan arti bentuk, teknik, substansi dan konsep berpikir. Dengan demikian konsep berpikir, riset atau penelitian menjadi tahapan dalam berkarya seni proses pembelajaran mengenai seni lukis didasarkan bagaimana bisa melukis dengan berpikir dan merasakan dengan baik realitas sosial budaya, dan bukan bagaimana melukis itu sebagai sebuah ekspresi diri yang diungkapkan dengan baik.

Memberikan makna realitas sosial budaya dalam pandang yang lebih luas, dalam perkembangan masyarakatnya. Karya lukisan lahir dari sebuah gagasan dan kreativitas yang menginterpretasi realitas sosial budaya masyarakat berdasarkan riset atau pengamatan dan pengalamannya.

Dengan demikian karya seni seharusnya menjadi nilai keindahan dari lukisan itu sendiri, lebih menonjol, sehingga bisa dikedepankan. Dengan demikian orang yang bisa melukis, adalah orang yang mampu membuat lukisan itu menjadi keindahan dan bermakna bagi kehidupan.

Sebagai artikulasi budaya dari sebuah kehidupan manusia di dalam bermasyarkat. Seni lukis berkembang, sehingga setiap masyarakat dan komunitas dari suku bangsa mempunyai keindahan dan kaidah budaya masing-masing. Memberikan suasana masyarakat menjadi lebih baik dan mengerti realitas sosial budaya sebagai kehidupannya.

Sebuah karya seni seharusnya memiliki keindahan yang didasarkan dari sebuah obyek yang diambil dari realitas yang dihayati dalam dirinya. Sebuah pengalaman seseorang di dalam kehidupan sehari-hari agar dapat dijadikan dasar dalam membuat karya seni lukis.

Seni lukis seharusnya sebagai media untuk mengembangkan ekespresi dirinya, sehingga sebuah pengalaman menjadi sesuatu 
yang memberikan nilai pada dirinya. Berhimbas pada kehidupan realitas sosial budaya masyarakatnya.

Membentuk seni lukis sebagai ekspresi diri agar dapat mengungkapkan pengalaman, berupa sebuah gagasan, perasaan maupun imajinas, meskipun lebih menekan pada kemanfaatan pada dirinya sendiri. Namun berdampak pada kehidupan masyarakat pada umumnya.

Dengan demikian pembelajaran seni lukis lebih mengakomodir seseorang. Agar bisa mengekspresikan diri melalui media seni lukis secara lebih baik, dan mudah mengembangkan dirinya secara tepat dalam kehidupan. Karya lukisan mampu mengharmoniskan realitas sosial budaya masyarakat diantara setiap orang.

Untuk itu pembelajaran seni lukis seharusnya menekankan pada bagaimana seseorang melukis agar dapat mengekspresikan diri sepenuh hati. Realitas sosial budaya seni lukis mengembangkan nilai dan kaidah kehidupan masyarakat.

Realitas sosial budaya memberikan kebebasan pada setiap orang untuk melukis sesuai dengan keinginan dirinya. Dengan menginterpretasikan sebuah realitas sosial budaya, baik dalam obyek alam benda, figur atau pun lingkungan dan pemandangan alam.

Kebebasan menginterpretasikan ini memberikan banyak kemungkinan pada setiap orang untuk mengembangkan kreativitas dengan baik. Akan tetapi pengembangkan itu hanya dibingkai pada pemahaman, untuk mampu membuat lukisan menjadi indah dan bermakna.

Sebagai sebuah bentuk, bukan segala sesuatu keutuhan dari karya seni lukis yang dibuatnya, yang di dasarkan pada kemampuan setiap orang mengekspresi dirinya secara baik. Dari proses interaksi sosial dan gagasan dalam karya lukisan. 
berdasarkan pengalaman dari pemikirannya sendiri. Sebagai proses dari interpretasi di dalam berkarya dan melihat karya lukisan.

Sebagai sebuah tahapan dalam dalam belajar melukis, agar sampai pada kesadaran di dalam melihat kehidupan sebagai realitas sosial masyarakat yang berbudaya. Sebagai tahapan dalam menginterpretasikan sebuah obyek lukisan dalam sebuah karya seni lukis.

Begitu juga ada model pembelajaran melukis dengan magang seperti yang dilakukan para pelukis sebelumnya, seperti Sudjojono, Affandi dan Nashar. Model pendidikan magang yang dilakukan pada pendidikan sanggar. Model pembelajaran yang lebih menekan pada kondisioning seorang yang belajar seni lukis dipengaruhi oleh lingkungannya.

Melukis secara langsung sangat mendukung dalam pembelajaran melukis, karena belajar langsung pada seorang pelukis yang tidak diragukan ketokohannnya. Dengan demikian seseorang belajar seni lukis hanya di dasarkan pada ketokohan dan kemampuan pelukis terkenal. 


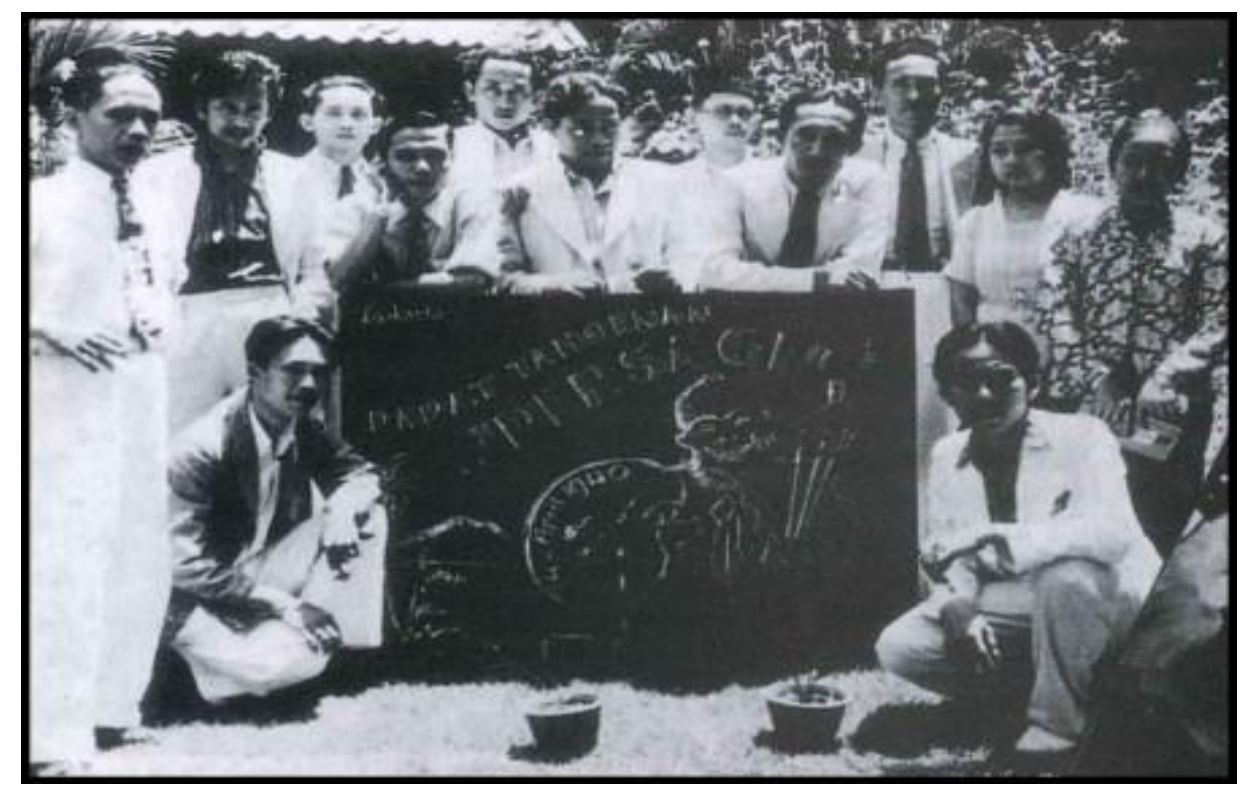

Gambar 11, PERSAGI, Perkumpulan Pelukis Indonesia (www.jakarta.go.id)

Untuk itu proses pembelajaran seni lukis pada masa lalu lebih pada pendekataan personal terhadap minat dan keinginan untuk mau belajar seni lukis pada seorang yang mempunyai kemampuan melukis. Menjadikan seorang pelukis sebagai orang guru yang mengajarkan melukis seperti apa yang dilakukan pada orang lain.

Dengan demikian pendidikan seni lukis di Indonesia dimulai dengan berdirinya PERSAGI. Mulai dari Persatuan Ahli Gambar Indonesia (PERSAGI), Seniman Indonesia Muda (SIM) yang dipelopori Sudjojono sampai berdirinya Akademi Seni Rupa Indonesia (ASRI) di Jogyakarta, kemudian di Institut Teknologi Bandung di mana senirupanya bagian dari Fakultas Arsitektur yang mengajar orang Belanda Ries Mulder yang mengajarkan melukis sesuai dengan pengajar ketika melukisnya. 
Belajar kehidupan itu melalui garis, sapuan, bentuk, warna, bidang dan keharmonisan. Dengan demikian prinsip dan prosedur dalam bidang Teknologi Pendidikan mampu memberikan tahapan yang lebih tepat dalam memenuhi kebutuhan setiap orang di dalam belajar seni lukis.

Di mana model pembelajaran seni lukis yang akan diberikan mengakomodir kebutuhan yang lebih menekankan pada karakternya disamping prinsip-prinsip budaya yang hidup dalam masyarakat.

Dengan pembelajaran berbasis realitas sosial budaya yang memberikan interpretasi ruang pada setiap orang, untuk menumbuh kembangkan diri dalam seni lukis. Akan membawa dirinya pada keunikan diri dan kesadaran dirinya terhadap kekurangan dan kelebihannya. Membuat seni lukis menjadi bidang yang bukan hanya sekedar keahlian, tapi pembentukan diri manusia melalui bahasa rupa, yang bermakna dan berarti.

Dunia kesenian dikalangan masyarakat luas di identifikasi dengan kegiatan kreativitas pelakunya. Dimana kreativitas direprentasikan kegiatan pemikiran, kemampuan teknis, rasa atau intuisi yang berkaitan dengan afektif, kepribadian seorang seniman. Hal itu terlihat dari hasil karya seni yang dibuatnya dan dilihat oleh masyarakatnya.

Begitu juga dengan kerja seni lukis selalu mencerminkan gagasan yang cemerlang. Mampu diimplementasikan dan dilihat dari hasil karya seni baik itu seni lukis, patung, grafis. Begitu juga dalam karya seni lainnya seperti desain, interior, mode, kriya, seni pertunjukan dan film.

Masih terlihat seni murni dari karya seni lukisnya. Hal ini memperlihatkan kemampuan dan kekuatan gagasan dan kreativitasnya. Di dalam mengolah sebuah tema dan permasalahan yang akan dibuatnya. 
Tetapi ketika kita akan menyelami dunia seni yang diwarnai dengan kreativitas dan gagasan, sehingga gagasan yang cemerlang tidak ditemui dalam dunia industri. Walaupun kegiatan berkesenian yang ada di dunia kerja seni tidak ada bedanya dengan dunia lain.

Seperti orang yang bekerja di kantor, dengan rutinitas yang dikerjakan, sesuai dengan program dan rencana yang telah ditetapkan. Hanya saja seorang pelukis sendiri yang mengatur waktu sesuai dengan kebutuhan, sehingga tidak selalu sama dengan masyarakat pada umumnya.

Begitu juga ketika membuat kerja seni tidak bedanya dengan orang yang membuat mebel, seni lukis pinggiran jalan yang hanya meniru karya fotografi yang digambar dalam kanvas. Sehingga yang diperlukan hanya ketrampilan. Tidak ada yang menarik untuk dimunculkan kepermukaan sebagai bahan kajian dalam seni.

Ini yang terjadi dalam dunia perguruan seni untuk mengembangkan nilai seni yang lebih baik agar terlihat dengan baik. Walaupun dalam melihat karya seni yang terpenting adalah dari seni bentuk karyanya.

Tetapi karya seni itu juga menjadi sesuatu yang tak berarti karena tidak banyak bicara. Yaitu berbicara mengenai permasalahan gagasan yang ingin diungkapkan. Bukan sekedar bentuk atau ketrampilan teknik, meskipun menjadi faktor utama dalam berkarya.

Hendaknya kita dapat menempatkan teknik sebagai bagian media gagasan, ide yang merupakan representasi dari sebuah kreativitas seorang pelukis atau pekerja seni. Dan kreativitas itu kemudian muncul menjadi sebuah kerja seni yang membawa nilai pembaharuan yang disebut dengan seni yang inovatif.

Karya seni telah memberikan pencerahan bagi cara pandang kesenian didalam melihat persoalan yang kompleks di masyarakat. Dibuat menjadi sesuatu yang mudah dicerna dan dipahami oleh masyarakat, tanpa harus menjelaskan karyanya. Inilah yang kiranya 
selalu menjadi permasalahan yang ada didalam dunia seni. Tidak semua masyarakat pada umumnya mengerti bahasa rupa yang diungkapkan para seniman, pelukis pada khususnya.

Untuk itu perlu ada sentuhan rasionalitas didalam penciptaan. Karena dengan adanya rasionalitas dalam seni, maka seni lukis makin diperlukan dengan berbagai bagian untuk terwujudnya ungkapan yang utuh. Kemampuan menangkap tema permasalahan lebih baik dan mudah mencapai sasaran dalam realitas sosial budaya masyarakat. Karya lukis pada akhirnya memang harus diapresiasi masyarakat, sebagai refleksi dari realitas sosial budaya masyarakatnya.

Rasionalisasi bukan berarti menyampingkan nilai, tapi lebih melengkapi dan mempermudah proses berkarya. Seni lukis menjadi lebih mudah dipahami sebagai sebuah kesadaran seorang pelukis terhadap keberadaanya. Sebagai seorang manusia yang mengungkapkan nilai-nilai kehidupan yang luas dan kompleks. Menjadi lebih sederhana, namun mudah dirasakan oleh masyarakatnya.

Dengan demikian bisa dipahami secara lebih baik dan mencapai sasaran yang akan ditujunya. Itulah perlunya ada satu kesadaran yang memberikan pencerahan didalam berkarya atau kegiatan berkesenian dengan cara mengetahui dan memahami seni didalam berkarya. Maka dengan itu diharapkan kita bisa lebih mudah lagi untuk menggali potensi dan kreativitas berkesenian secara berkesinambungan.

Masalah yang ada di dalam seni, semua unsur dicoba untuk menggali potensi yang ada di dalam kerangka berpikir seniman. Menggali potensi perasaaan dan emosional menjadi sesuatu bentuk yang memberikan warna dan ekspresi.

Kesenian pada dunia rasa yang dapat menjelajahi ke dalam sanubari yang lebih dalam. Membuat seni lukis pada pola dan kepribadian, hal ini akan berpengaruh pada pola dan kehidupan 
seseorang yang ulet, militan dalam meyakini nilai kesenian, yang mengarah pada nilai kebenaran.

Di mana kebenaran itu bisa terasa dengan tumbuh dan diasah hati nurani kita sebagai manusia yang mempunyai fitrah kepada nilai kebaikan. Kebaikan merupakan manifestasi nilai keindahan karya seni yang dibuat oleh kita di dalam mengekspresikan nilai-nilai kemanusiaan.

Dengan begitu penciptaan yang kita pahami sebagai satu kesatuan didalam proses berkarya seni, tidak hanya membicarakan masalah teknik atau elementer seni rupa yang menyangkut: irama, bidang, garis, ruang dunia dimensi, tiga dimensi dan mixmedia atau multimedia, dengan warna, cahaya, komposisi dan sebagainya.

Meskipun itu penting, tapi bukan berarti kita tidak membahas metodologi pada segi filosofis, sejarah, sosial dan budaya yang berkaitan dengan proses penciptaan, akan menambah dan memperkaya khasanah pemikiran, pengalaman kita didalam berkarya.

Maka dengan itu penciptaan seni tidak terjebak sekedar kiatkiat di dalam membuat karya seni yang lebih baik. Tapi lebih luas lagi didalam melihat proses berkarya seni menjadi suatu kekayaan yang jauh lebih penting dan sangat berharga lagi kita di dalam berkesenian di masa akan datang.(Kreativitas Punya Kita Semua : 58)

Seni lukis salah satu media, yang mempunyai dua dimensi, menjadi media ekspresi seorang pelukis. Dalam mengungkapkan ide dan gagasan yang dilatar belakangi dengan sosial budaya. Di mana dia dilahirkan dan dibesar sebagai seorang yang mempunyai nilai budaya.

Nilai budaya itu yang dibawanya sebagai sebuah kehidupannya. Seni lukis sebagai sebuah gambaran realitas dari seorang pelukis terhadap realitas sosial budaya di mana masyarakat tumbuh dan berkembang. Untuk mewarnai kehidupannya. 
Gambar ini menjadi sebuah kesadaran seorang pelukis, untuk dapat mengispirasikan. Memberikan gambaran sebuah sejarah, sejarah sedang berlangsung. Sejarah masa depan dalam kehidupan sosial budaya yang akan datang. Seorang pelukis bias juga memprediksi sebuah kehidupan masyarakat sosial budaya masa akan datang. Kesadaran terhadap realitas sosial budaya ini menjadi sebuah tanggung jawab seorang pelukis.

Dengan demikian teknik melukisnya bisa dikembangkan menjadi kreativitas yang lebih baik, sebagai bentuk sumbangsih pada dunia seni lukis. Mengembangkan sosial budaya masyarakat, karena memberikani pencerahan dan inspirasi.

Dalam bentuk yang sangat mudah dikenalkan tapi mempunyai kemampuan teknik yang baik. Ide dan gagasan dalam karya seni sangat terlihat dengan baik. Paduan antara ide dan gagasan serta teknik berkarya dengan baik, memberikan hasil karya yang baik. Meski dengan media yang sangat sederhana.

Kemampuan berkarya seni itu memberikan konstribusi pada kehidupan masyarakat yang berkaitan dengan sebuah pemikiran dan inspirasi untuk membangun kesadaran masyarakat terhadap lingkungan dan kehidupan sosial budayanya. Dengan demikian menumbuhkan sikap hidup masyarakat dan mahasiswa dalam kesadaran pada nilai kehidupan yang berkaitan dengan nilai etika, moral dan agama.

Spiritualitas masyarakat menjadikan kehidupan masyarakat adil dan sejahteraan. Sebagai sikap bangsa yang berbudaya dan beradab, di mana sikap tolerasi dan gotong royong. Kemampuan berkarya bukan semata-mata sebuah ketrampilan bagi mahasiswa. Tapi sebagai sebuah pengembangan pengetahuan seni dari aspek sosial budaya yang ada di dalam kehidupan masyarakatnya.

Kemampuan teknik itu menjadi representasikan ide dan gagasan sosial budaya dalam seni lukis. Dengan demikian kemam- 
puan pengetahuan realitas sosial budaya di dalam berkarya bisa mengembangkan dan memberikan inspirasi.

Kemampuan interpretasi itu sebagai kreativitas di dalam berkarya, sehingga tidak terpaku pada kemampuan teknis saja. Tapi menjadi stimulasi diri seorang pelukis, mahasiswa untuk mengolah jiwa dan rasa, sehingga memperkaya realitas sosial budaya, di dalam kehidupan masyarakatnya. Kreativitas selalu menjadi kekuatan di dalam proses berkarya seni lukis, untuk dapat menangkap persoalan dengan baik.

Bukan itu saja selain mampu membuat karya lukisan yang baik, dan mampu menjelaskan proses berkarya seni lukis. Bagaimana membuat karya seni lukis ini dengan baik. Dengan menjelaskan tahap-tahapan berkarya seni lukis. Begitu juga bisa membuat lukisan yang didasarkan gagasan realitas sosial budaya.

Selain itu mengadakan orientasi pengetahuan mengenai seni lukis mahasiswa, untuk bisa memahami pengetahuan dan kemampuan di dalam membuat karya seni lukis. Dengan melihat karya seni lukis yang telah dibuat sebelum, akan memasuki materi pembelajaran seni lukis berikutnya. Sebagai pengembangan diri dalam proses membuat karya lukisan selanjutnya.

Setiap mahasiswa mempresentasikan karya lukisnya, dengan menjelaskan lahirnya karya seni lukis dengan gagasan dan kreativitasnya untuk membuat lukisan. Dan bagaimana proses pembuatnya karya lukisan dan teknik melukis apa yang dipakainya. Dengan teknik melukis itu membuat karya seni lukis melahirkan gaya lukis apa bagian dari gagasan atau bagian dari teknik yang dibuatnya.

Gagasan dan teknik dalam pengarapan karya seni didasarkan tema yang didapat dalam sebuah pengalaman hidupnya, bisa juga dari pengetahuan mengenai sesuatu yang berkaitan 
box dan metode gambar. Dibidang seni rupa metode ini disebut proses menggali konsep atau gagasan.

1) Metode Craft, menurut teori Jones (1979), karya kerajinan adalah warisan lama yang pembuatannya secara manual dan bukan produk pemikiran ilmiah seperti pembuatan barang di zaman modern. Metode craft adalah produk yang dihasilkan melalui perubahan terus-menerus sampai terbentuknya sebuah karya yang kita kenal sekarang, seperti ukiran dan keris.

2) Metode Black Box (Metode Inspirasi), memunculkan konsep di mana asal-usul konsep sebuah karya adalah hasil renungan atau inspirasi

3) Metode Glass Box (Metode Analisis-Sintesis), di mana dalam proses berkarya seni membutuhkan data-data, kemudian diolah atau diproses, hasil pengolahan data ini kemudian menghasilkan gagasan baru di mana diperoleh konsep-konsep atau teori untuk diterapkan pada karya.

4) Metode Gambar (Konsep Grafis), menurut Jones, sebuah konsep bisa lahir melalui gambar, di mana seorang mencoba menggali ide dan gagasan melalui beberapa sketsa, kemudian memilih sketsa yang baik. McKim (1980; 144) menyebut cara ini sebagai "berpikir visual" yang melibatkan tiga komponen yaitu (1) berpikir, (2) menyimbol dan (3) merujuk. Proses kreatif dengan cara melihat, berpikir, menyibolkan dan merujuk, serta menggerakan tangan secara komprehensif untuk di internalisasikan.

5) Metode Riset (Penelitian), Bahwa praktek seni dan desain sebagai praktek riset. Seseorang menggambar, melukis atau mendesain obyek-obyek sebenarnya melakukan penelitian dari obyek yang dikerjakan, tetapi hal ini belum mendapat pengakuan. 
6) Praktek Seni Berbasis Riset dan Riset Pratek Seni, ada dua cara yang dilakukan, pertama studio berbasis riset (studio based research) memfokuskan diri dengan mengadakan riset sebelum berkarya dan memperlihatkan pengetahuan baru yang diperoleh melalui karya desain, musik, performance, media digital maupun pameran. Kedua Riset praktek studio yang memfokuskan studi teks yang mendalam tentang praktek seni itu sendiri tanpa dibebani membuat karya.

7) Teori Tindakanan, bahwa seni adalah gejal tindakan sosial dan budaya dalam rangka "makna seni bersama", kehadiran karya seni tidaklah semata akibat tindakan pribadi.(Nasbahrya Couto \& Minarsih; 2009;32-42)

\section{Pengembangan Kreativitas Seni Lukis}

Pengembangan adalah suatu usaha untuk meningkatkan kemampuan teknis, teoritis, konseptual, dan moral seseorang sesuai dengan kebutuhan pekerjaan melalui pendidikan dan latihan.

Menjelaskan pengertian kreativitas berkarya, berkaitan dengan realitas sosial budaya sebagai bentuk dan isi dalam seni lukis. Pengembangan gagasan berkarya itu lahir dari proses berpikir tentang sesuatu, yang dipikirkan secara terstruktur, dimana apa yang sedang dipikirkan itu dikumpulkan menjadi sebuah susunan yang menghasilkan bentuk baru atau menjadi karya seni lukis.

Maupun dengan proses berpikir tidak terstruktur atau pola pikir yang melompat-lompat, dimana dalam melihat permasalahan, realitas tidak selalu puas dengan berurutan atau tersusun kalau permasalahan itu bisa diatasi denga jalan pintas, sehingga menjadi singkat kenapa tidak.

Sedangkan kreativitas adalah proses penggabungan gagasan satu dengan gagasan yang lain menjadi gagasan yang satu. Sehingga melalui alam bentuk yang berbeda atau karya seni 
Karya lukisan dua wajah yang berbeda dalam dua sisi, sisi satu berwajah Monalisa dan sisi lainnya wajah Leonardo da Vinci. Sebagai sebuah gambarkan bahwa lukisan ini ingin menjelaskan bahwa apa yang dilukiskan Leonardo tentang seorang wanita, sebenarnya berangkat dari lukisan wajahnya sendiri.

Karya lukisan ini menjelaskan mengenai kemampuan seorang pelukis di dalam analogikan permasalahan diri dalam bentuk obyek keindahan karya lukisan. Sebagai pandangan seorang pelukis dalam melihat sebuah obyek yang kadang menimbulkan ilusi, sehingga memberikan gambar obyek dalam dua sisi yang berbeda. Dengan demikian cara padang dalam ilusi, imaji seorang pelukis tidak tunggal, tapi memberikan pandangan dan bentuk yang berbeda dan berubah, namun satu kesatuan dari gagasan. 


\section{Glosarium}

Interpretasi : Tanda yang berkembang dari tanda telah lebih dahulu ada dalam benak orang yang menginterpretasikannya.

Gagasan : Lahir dari proses berfikir tentang sesuatu yang difikirkan secara terstruktur, dimana apa yang sedang difikirkan itu dikumpulkan menjadi sebuah susunan yang menghasilkan bentuk baru atau menjadi karya seni.

Konsep : berasal dari bahasa latin conceptum, Konsep Adalah, Ini Penjelasan Mengenai Arti Konsep yang artinya sesuatu yang dipahami.

Konsep gagasan : Sesuatu yang dipahami sebagai sebuah rancangan yang tersusun di pikiran, sesuatu gambar imajinasi. Dalam dunia seni lukis konsep gagasan menjadi satu kesatuan dari pemikiran, pengalaman dan penghayatan yang bersifat internalisasi diri seorang pelukis. Sebagai sebuah keindahan dalam berkarya seni lukis bagi seorang pelukisnya.

Kreativitas : Proses penggabungan gagasan satu dengan gagasan yang lain menjadi gagasan yang satu. Sehingga melalui alam bentuk yang berbeda atau karya seni berbeda.

Metodologi : Ilmu atau cara yang digunakan untuk memperoleh suatu kebenaran dengan menggunakan penelusuran dengan urutan atau tata cara tertentu sesuai dengan apa yang akan dikaji atau diteliti secara ilmiah

Model pembelajaran : Sebagai prosedur sistematis dalam mengorganisasikan pengalaman belajar untuk mencapai tujuan belajar.

Pengembangan : Suatu usaha untuk meningkatkan kemampuan teknis, teoritis, konseptual, dan moral seseorang sesuai dengan kebutuhan pekerjaan melalui pendidikan dan latihan.

PERSAGI : Persatuan Ahli Gambar Indonesia, Seniman Indonesia Muda (SIM) yang dipelopori Sudjojono sampai berdirinya Akademi 
Seni Rupa Indonesia (ASRI) di Jogyakarta, kemudian di Institut Teknologi Bandung di mana senirupanya bagian dari Fakultas Arsitektur yang mengajar orang Belanda Ries Mulder yang mengajarkan melukis sesuai dengan pengajar ketika melukisnya.

Proses berpikir : Mengingat kembali adalah membangun hubungan-hubungan sehingga benda atau kejadian yang ingin kita kenali berada kembali dalam suatu konstelasi dunia yang ada di dalam benak kita.

Semiotika : Sebagai studi tentang tanda dan segala yang berhubungan dengan tanda; cara berfungsi (sintaktik semiotik) dan hubungan antar tanda (semantik semiotik), serta mengakaji pengirim dan penerimanya oleh mereka yang mengunakan tanda (pragmatik semiotik)

Tanda : disebut dengan represent, yaitu sesuatu yang mewakili sesuatu lain yang diacunya. 


\section{DAFTAR PUSTAKA}

1. Nashori, Fuad. 2002. Mengembangkan Kreativitas Dalam Perpektif Psikologi Islam. Yogyakarta: Penerbit Menara Kudus.

2. Yasraf, Piliang Amir. 1998. Sebuah Dunia Yang Dilipat. Bandung: Penerbitan Mizan.

3. Geoffry, Petty. 1997. How To Be A Better At Creativity. London: Kogan Page.

4. Dadan, Rusmana. 2014. Filsafat Semiotika. Bandung: Penerbit Pustaka Setia.

5. Dharsono, Sony Kartika. 2004. Seni Modern. Bandung: Penerbit Rekayas Sains.

6. Mike, Susanto. 2003. Membongkar Seni Rupa. Yogyakarta: Penerbit Buku Baik dan Jendela.

7. Babang, Sugiharto. 2015. Untuk Apa Seni. Bandung: Penerbit Matahari.

8. Nielsen,Thomas William. Robert Fitzgerald and Mark Fettes. 2010. Imagination in Educational Theory and Practice.Chambrige: Scholars Publishingh.

9. Van, Zoest Aart. 1993. Semiotika; Tentang Tanda, Cara Kerja dan Apa Yang Kita Lakukan Dengannya. Jakarta: Penerbit Yayasan Sumber Agung.

10. Bagoes P, Wiryomartono. 2001. Pijar-Pijar Penyingkap Rasa. Jakarta: Penerbit Gramedia.

11. Data dari Internet bocahgembluduk.blogspot.com,www.tripadvisor.com 
Menguasai konsep dasar seni rupa dan teknik melukis akan mampu berkarya seni lukis pada tataran konsep. Dengan belajar mengenai dunia seni lukis untuk mewujudkan konsep dasar seni rupa yang lebih luas dan mampu memberikan makna dari sebuah obyek yang dilukisnya.

Lebih lanjut akan mampu mengembangkan teknik dan media dalam berbagai macam aplikasi dalam karya seni lukis. Akan bisa dilihat dalam membuat tugas karya seni lukis sebagai bentuk hasil dari apa yang dipahami tentang konsep dasar seni rupa.

Menjelaskan bagaimana teknik melukis lahir di dalam berkarya seni lukis. Didasarkan pada pemahaman realitas sosial budaya. Dengan membuat karya seni lukis yang menjadi tugas untuk diselesaikan. Dari tugas seni lukis yang dibuatnya diharapan akan terlihat bagaimana mahasiswa bisa membuat karya lukisan berangkat dari realitas sosial budaya.

Mampu membuat karya lukisan dengan tahapan yang baik. Dan akan mampu menjelaskan dan mengembangkan gagasan berkarya seni lukis berbasis realitas sosial budaya. Melahirkan teknik melukis yang lebih baik dari sebuah teknik. Untuk bisa dikembangkan di dalam proses berkarya seni di dalam realitas sosial budaya.

Konsep pembelajaran seni lukis sebagai cara berkarya seni lukis dan berpikir tentang seni lukis secara struktur. Mampu dan menguasai teknik melukis dengan baik dan juga bisa memberikan pemahaman tentang lahirnya sebuah karya seni lukis dari sebuah latar belakang realitas sosial budaya. Membuat karya seni lukis sebagai ekspresi hidup dan realitas sosial budaya. 


\section{Teori Dasar Seni Rupa}

Teori menurut kamus besar bahasa Indonesia mempunyai pengertian 1) pendapat yang didasarkan pada penelitian dan penemuan, didukung oleh data dan argumentasi; 2) penyelidikan eksperimental yang mampu menghasilkan fakta berdasarkan ilmu pasti, logika, metodologi, argumentasi: - tentang kejadian bumi; tentang pembentukan negara; 3) asas dan hukum umum yang menjadi dasar suatu kesenian atau ilmu pengetahuan.

Teori adalah pokok pertama/utama yang mendasari keseluruhan pemikiran. Konsep biasanya hanya ada dalam pikiran atau kadang-kadang tertulis secara singkat. Dalam penyusunan ilmu pengetahuan diperlukan kemampuan menyusun teori dasar yang dapat diuraikan terus menerus, kemampuan abstrak (menyusun kesimpulan) tersebut dinamakan pemikiran konseptual.

Pada pandangan Dewey, rasa meningkatkan pemahaman dalam seni rupa berasal dari kenyataan bahwa pengetahuan ditransformasikan baik dalam produksi dan berdasarkan pengalaman dengan digabungkan dengan unsur-unsur bukan intelektual. Hidup ini dibuat lebih dimengerti oleh seni bukan karena konseptualisasi tetapi melalui klarifikasi dan intensifikasi berdasarkan pengalaman.

Pembentukan teori merupakan kongkritisasi indra, dalam suatu proses yang pelik, senggah mencakup penyerapan metode, pengenalan seperti perbandingan, analisis, abstraksi, idealisasi dan bentuk-bentuk deduksi yang pelik. Keberhasilan teori ditentukan oleh pemantulan realitas obyektif di dalamnya. Teori sangat berarti dalam berkarya seni. la dapat lahir sebelum, bersamaan, maupun setelah pengerjaan sebuah karya seni. Teori dapat menjadi pembatasan berpikir seorang pelukis maupun penikmat dalam melihat dan mengapresiasi karya seni. Sehingga seorang pelukis 
Dengan demikian seorang pelukis dapat melihat tentang masalah realitas sosial budaya di mana dia berada dalam satu lingkungan masyarakat. Untuk bisa mengembangkan sikap dan pandangan berkesenian yang sudah ada dalam realitas kehidupan masyarakat. Untuk itu elemen seni rupa dapat dipahami, sebagai berikut :

\section{1). Garis}

Garis adalah sebagai kumpulan dan rangkaian titik-titik yang memberikan satu kesatuan yang disebut dengan garis. Garis dapat membentuk sebuah ruang, dimensi dan gambar yang menggambarkan sebuah obyek dalam lukisan, seperti alam benda, pemandangan, figur dan kehidupan dalam sebuat ekspresi.

Garis dalam karya seni lukis bisa menjadi sebuah tahapan melukis. Dengan membuat sketsa lukisan, dimana di dalam perkembangannya sketsa seni lukis menjadi karya seni tersendiri, dari karya lukisan yang ingin dibuat.

Garis dalam pengetahuan bahan seni lukis, berdasar teknik dasar seni lukis. Mempergunakan material kering, yang terdiri dari pencil, arang atau charcoal dan pastel, mempergunakan bidang datar kertas.

Meskipun tidak menutup kemungkinan sebagai media utama atau pendamping, di bidang datar lain. Namun sering yang di-pergunakan untuk media pendamping, yang sering dipakai adalah pensil. Pensil untuk membuat sketsa, sebelum mempergunakan material basah, seperti cat air, akrilik dan cat minyak.

Garis sebagai elemen seni rupa sebagai konsep seni lukis memberikan konsep dan makna yang dibangun dalam berkarya. Garislah yang merepresentasikan pemahaman realitas sosial budaya, berkembang selain menjadi bentuk tapi juga sebagai pengetahuan tentang seni dan estetika. Sebagai bentuk inter- 
pretasi seorang pelukisan dalam melukiskan alam benda, pemandangan alam dan figur.

Begitu juga dengan kesatuan garis menjadi elemen ruang dan dimensi yang lebih luas dan mendalam. Memberikan bidang keahlian bukan pada bentuk tapi ruang dan waktu dalam sebuah film dan seni pertunjukan. Garis itu bisa bermetamorfosa, sebagai garis cahaya dalam dunia film dan seni pertunjukan, garis frame dalam sebuah pandangan kamera, menjadi frame by frame.

Perkembangan garis dalam karya seni lukis terus mengalami perubahan, sejalan dengan perkembangan konsep berkesenian. Seorang pelukis, selain memahami garis sebagai sebuah realisasi bentuk. Tetapi juga sebagai sebuah konsep garis yang lebih bermakna dari ekspresi seorang pelukis.

Garis bukan sebagai bentuk garis saja, tapi garis sebagai sebuah tanda dari konsep berpikir dan rasa dari seorang pelukis terhadap tema yang dibuatnya.

Garis juga bukan sebagai garis bentuk yang bermakna dari sebuah tanda tapi juga mengalami simbolisasi, contohnya adalah katulistiwa yang membentak di pulau kalimantan.

Garis sebagai bentuk metafora dari sebuah lukisan adalah dengan membuat garis kehidupan, dengan mempergunakan bentuk garis, maupun elemen media lain yang menggambarkan kehidupan.

Garis dalam karya seni lukis bukan pada masalah garis dari sebuah pencil, pulpen atau pena, tapi juga sapuan kuas. Untuk mencapai naturalisme terbesar dan tingkat tertinggi kepuasan dalam lukisan, pelukis harus sangat hati-hati mempelajari kualitas garis yang dibentuk oleh persimpangan dari pesawat yang berbeda sehingga penelitian cahaya dan bayangan (chlaroseure) tampaknya bagian paling penting Alberti dari pelatihan pelukis. 
Memberikan bentuk garis berwarna kuning membentang sebagai pemandangan, lingkup danau pada kesatuan lingkungan. Garis yang melingkup sebuah lingkuangan, dan masyarakat yang menyaksikan karya seni lingkungan dengan bentuk seni instalasi, sebagai karya seni monumental.

Masyarakat yang menyaksikan bukan saja sebagai penonton, tetapi juga sebagai yang terlibat dalam karya seni lingkugan. Terlihat dalam satu kesatuan garis berwarna kuning, danau dan lingkungannya serta masyarakat yang merasakan dan nikmat diatas garis warna kuning.

Garis bentuk panjang membentang yang mempergunakan teknik yang tidak biasa itu. Memperkuat bahwa garis bukan saja membentuk tapi juga garis sebagai bentuk dengan mempergunakan teknik yang sangat dipertimbangkan.

Konsep dasar dari bentuk garis menjadi sebuah bentuk bidang dan ruang yang melingkupi daun yang bisa dilalui manusia, seperti jalan raya yang beraspal. Ada sebuah perubahan tanda garis sebagai bentuk dan bidang yang mempunyai konstruksi kuat dan paduan seni. Memperkuat struktur konstruksi menjadi sebuah bangunan "jalan".

\section{2). Bentuk}

Bentuk dalam teori psikologi Gestalt berkaitan dengan persepsi manusia terhadap realitas bentuk. Dalam melihat bentuk sebagai satu kesatuan, untuk mengembangkan sejumlah asas yang mengatur persepsi manusia.

Prinsip psikologi Gestalt adalah adanya kesatuan dalam persepsi kita terhadap bentuk. Kesatuan ini dibentuk oleh seorang pelukis melalui elemen seni dengan berbagai latar belakang bentuk dari karya lukisan yang dibuatnya. 
Bentuk juga dapat dilihat dalam dua macam bentuk yang masing-masing mempunyai sifat yang berbeda antara satu sama lain, sebagai berikuti;

a. Bentuk Biomorfis, sebagai bentuk alami, dari bentuk organisme, seperti cacing, amuba yang memberikan bentuk alamiah lebih mengalir dan mengalun, sehingga terlihat organis bentuk yang lembut, melengkung dan terlihat dinamis, fleksibel. Meskipun bentuk pada struktur ujung, akhir lengkungan, tapi tidak menutup kemungkinan mengkristal.

Karya Nashar menjadi sebuah karya seni rupa kontemporer Abstraksi Biomorfis, membentuk sebuah atmosfir yang menyatu pada bentuk dan berkembangan pada pengalaman yang terus mengalir dan menyelusuri bentuk dan makna dengan keluwesannya. Dibuat dengan tahapan yang dimulai dengan mewarnai bidang kanvas, dan selanjut berjalan dari warna satu kewarna berikutnya. Saling tumpang tindih, sehingga memberikan aksentuasi warna yang berbeda dan transparansi warna sebelum dari warna yang diatasnya.

Bentuk terasa obyektif sebagai elemen bentuk yang memberikan makna dan interpretasi yang lebih luas dari sebuah pemahaman yang ada dalam sebuah gagasan. Sebagai sebuah ilusi pengelihatan, di mana sebuah obyek tidak bisa dilihat dan di makna dalam satu kesamaan. Dengan demikian akan menimbulkan penafsiran berbeda, tergantung dari mana melihat dan bagaimana memaknainya. 
Membuat garis dalam lukisannya tidak penting lagi, karena perubahan cahaya pada warna menjadi lebih terpancar, merata dan menguat pada bentuk lukisan. Meskipun setiap pelukis mempunyai intensitas masing-masing tergantung dari cara pandang dalam melihat pantul warna dalam obyek yang ditangkapnya.

Sedangkan Vincent van Gogh yang juga terinspirasi dengan tulisan Delacroix dalam surat-suratnya pada Teo saudaranya, menginginkan efek-efek warna luar biasa yang diimpikannya.

Dengan sapuan yang kasar van Gogh menghasilkan warnawarna yang terang, kontras dan kadang tidak bisa dikontrol, karena melukisnya terlalu meluap-luap. Karya lukisan van Gogh hingga dikenal dengan karya lukisan ekspresionisme.

\section{6). Sapuan}

Kuas menjadi sebuah alat dalam melukis untuk membuat lukisan dengan berbagai macam sapuan di atas bidang kanvas. Sapuan kuas itu bisa berupa bentuk, pengisi bidang kanvas sebagai dasar, mewarnai bentuk lukisan yang sudah dibuat sketsanya dari pensil.

Sapuan kuas juga sebagai alat untuk mengekspresikan perasaan yang meledak-ledak dengan keras dan tegas, sehingga menghasilkan karya yang kasar dan bertekstur.

Sapuan bagian dari elemen seni rupa yang membangunkan rasa dan emosi dalam konsep seni lukis yang dibuatnya. Sapuannya mengantarkan pada pemahaman bentuk dan gaya seni lukis yang di identifikasi, misalnya sebagai seni lukis abstrak, ekspresionisme, realis dan sebagainya.

Sapuan dalam lukisan bisa kenal dengan sapuan halus yang lebih menekan pada bentuk dan warna yang memberikan dimensi ruang, terang gelap serta terbentuknya obyek lukisan. 
Begitu juga lukisan dengan sapuan kasar, representasi perasaan yang meluap-luap. Seolah tanpa terkontrol, karena pelukis sudah mengalami trans, memasuki alam bawah sadar. Sedangkan sapuan ekspresif lebih menekan pada sapuan garis, warna dalam lukisan, sehingga menghasilkan karya lukisan yang sangat ekspresif.

Begitu luas fungsi sapuan dari di dalam sebuah proses berkarya seni lukis, mempunyai peran yang mampu melengkapi dari sebuah karya seni lukis. Dengan demikian akan menghasilkan seni lukis yang juga beragam dalam bentuk, gaya dan pemahamannya.

\section{7). Nada}

Nada sebagai konsep seni rupa menjadi elemen yang penting dari seni lukis. Sebagai pembeda dan dimensi jauh dekat dalam karya seni lukis yang ada obyek utama dan latar belakang obyek. Begitu juga dengan terang gelap dari warna menunjukkan pada nada warna yang berbeda.

Jauh dekat atau terang gelap bukan masalah konsep teknis seni rupa sebagai bentuk tapi sebagai pemahaman, pengetahuan, nilai dan keyakinan dari realitas sosial budaya manusia. Sebagai sebuah ekspresi seorang pelukis yang mempunyai makna yang ingin disampaikan, berdasarkan interpretasi terhadap realitas sosial budaya yang terjadi di masyarakatnya. 
kanvas atau kertas. Tapi dimana saja selama benda atau bidang itu bisa dilukis.

Semua itu berkaitan karya seni lukis dengan kesadaran kita melihat yang ada kaitan dengan barang yang tidak terpakai sebagai kepedulian terhadap lingkungan hidup. Membuat masyarakat mempunyai kemampuan di dalam menata lingkungan sosialnya dengan baik.

\section{Pengertian Seni lukis}

Menjelaskan pengertian seni lukis mempunyai banyak pengertian, tergantung konteks seni lukis ditempatkannya. Hal ini memperkaya kita dalam melihat pengertian seni lukis. Dengan demikian sebagai seorang pelukis bisa memahami dan menempatkan diri pada pengertian seni lukis, yang sesuai pada saat itu. Untuk itu bisa menempatkan pengertian itu pada konteksnya. Pengertian seni lukis juga bisa sebagai pengetahuan seni yang bisa menjadi sebuah karya lukisan berkembang menjadi sebuah karya seni. Untuk itu perlu ada uraian tentang pengertian seni lukis, sebagai berikut:

\section{a. Bentuk Seni Lukis}

Seni lukis sebagai sebuah karya seni mempunyai pengertian bentuk dua dimensi dan tiga dimensi yang bersifat ilusif. Seni lukis dengan media yang dipergunakan di dalam berkarya, tidak terbatas dalam media tertentu. Untuk itu seni lukis mempunyai pengertian berdasarkan pada media di dalam membuat karya seni.

Seni lukis dengan pendekatan teknik ini menggambarkan bahan dan media yang dipergunakan, mempergunakan bidang dua dimensi. Sebagai sebuah bentuk. Namun seni lukis sebagai 
sebuah karya ekspresi mempunyai pengertian yang lain seperti apa yang dijelaskan oleh para pengamatan dan pelaku seni lukis.

Seni lukis dapat dikatakan sebagai suatu ungkapan pengalaman estetik seseorang yang dituangkan dalam bidang dua dimensi (dua matra), dengan mengunakan media rupa, yaitu garis, warna, tekstur, shape, dan sebagainya.

Menurut W. Stanley Taft dan James W. Mayer, lukisan pada dasarnya merupakan sebuah gambar dua dimensi yang dilukis pada permukaan datar. Umumnya berbentuk persegi panjang, dan menggantung rata dengan dinding (I Gede Arya Sucitra, 2013: 5).

Pemahaman seni lukis sebagai sebuah bentuk seni lukis bidang datar. Sebagai dasar dari proses pembuatan karya seni lukis berbentuk dua dimensi. Dasar pemahaman bentuk seni lukis, sebagai konsep dasar seni lukis untuk bisa diaplikasikan pada bidang yang lebih dari tiga dimensi, bentuk ruang dan ukuran yang tak terbatas, sebagai sebuah konsep dari seni lukis.

\section{b. Penguasaan Teknik Seni Lukis}

Penguasaan teknik seni lukis sebagai wujud dari gagasan yang menegaskan kemampuan dan pencarian bentuk dalam seni lukis. Berkaitan dengan aktivitas melukis, penguasaan aplikasi teknik dan material bisa menjadi faktor yang sangat penting untuk keseluruhan penciptaan seni lukis.

Bagi beberapa pelukis aturan teknik dalam melukis dan kemampuan pengetahuan akan bahan seni lukis telah mengalami degradasi, bahkan menghilang. Lebih menekankan pada sebuah gagasan dalam membuat karya seni lukis, yang juga tidak membantu kemampuan teknik. Teknik melukis dasar gagasan, untuk mengembangkan teknik dan pengetahuan seni bagi seorang pelukis. 
Penguasaan teknik merupakan bagian paralel yang tak terpisahkan, bahkan amat menentukan dalam merealisasikan gagasan. Pencarian, penemuan dan pengunaan teknik dalam seni lukis, selain dipegaruhi oleh dorongan yang tumbuh dalam diri pelukis serta perkembangan gagasan dan media, sejalan pula dengan semangat zamannya. Teknik - teknik yang dipratikkan di masa lalu dan mendasari perkembangan di masa selanjutnya (Bambang Sugiharto 2015: 103)

Beberapa tahun belakangan ini, pengajaran seni murni lebih terkonsentrasi pada pengembangan gagasan dan ide serta konsep berkarya, dari pada pendalaman akan informasi yang berkaitan dengan sifat-sifat material lukisan. Bahwa penguasaan teknik dalam melukis, sebagai satu kesatuan dari pengetahuan seni lukis di dalam berkarya seni lukis.

\section{c. Material Seni Lukis}

Material seni lukis sebagai pengetahuan bahan yang dipergunakan, sesuai dengan kebutuhannya. Medium rupa dapat dijangkau melalui berbagai macam jenis material seperti tinta, cat atau pigment, tanah liat, semen dan berbagai aplikasi yang memberikan kemungkinan untuk mewujudkan medium rupa.

Rosalind Ragans menyatakan, dalam sebuah permukaan lukisan, material yang paling mudah ditangkap mata adalah elemen cat. Secara umum cat terbagi atas dua formulasi, yakni cat yang berbasis minyak (oil-based paint) artinya pelarutnya menggunakan minyak dengan binder linseed oil, pencairannya turpentine dan cat berbasis air (water-soluble paint) dengan pelarut air.

Menurut W. Stanley Taft dan James W. Mayer, cat apa pun jenisnya menempel di atas permukaan apa pun baik tekstur maupun reflektif kualitas, terdiri atas komponen dasar yang sama. 
Komponen yang kita tangkap sebagai warna dikenal sebagai pigmen, elemen yang biasanya berbentuk bubuk halus organik atau bahan anorganik.

Pigmen ini tersebar di cairan, yang memungkinkan akan menyebar dan mengikat elemen butiran bubuk di atas permukaan lukisan yang diterapkan. Cairan ini disebut pengikat (binder). Binder dapat berasal dari sejumlah minyak, telur, getah, atau polimer sintetik (akrilik, alkid). Pengikat ini memiliki karakteristik yang ketika mengering menghasilkan lapisan cat film yang stabil.

Fakta bahwa lukisan memiliki kandungan materi-bahan sering diabaikan atau tidak sepenuhnya dihargai. Hal ini disebabkan oleh terjadinya reproduksi karya seni sehingga yang kita lihat hanya tampilan dalam foto karya dan bukan wujud sebenarnya.

Ketika kita melihat lukisan yang sebenarnya, aspek material dapat menjadi sangat jelas tampak. Ketika melihat wujud nyata lukisan, dan secara sepakat kita juga mengakui bahwa itu dibuat dengan cara melukis (I Gede Arya Sucitra, 2013 : 3,6).

\section{d. Konsep Seni Lukis}

Lukisan juga tempat menyimpan (repositori) sejarah. Mereka telah mengalami keinginan manusia dan kekuatan alam. Sebuah studi dari waktu cara tertentu dan elemen telah mempengaruhi benda-benda dapat mengungkapkan kepada kita banyak tentang sifat-sifat bahan, dan cara di mana mereka dibuat.

Menurut Pringgadigdo seni lukis merupakan bahasa ungkap dari pengalaman arstistik maupun ideologi yang menggunakan garis dan warna, guna mengungkapkan perasaan, mengekspresikan emosi, gerak, ilusi maupun ilustrasi dari kondisi subyektif seseorang. Berikut beberapa rujukannya; pengambaran pada bidang dua dimensi berupa maksud. 
Seni lukis berupa maksud yang terkandung menjadi seni lukis selalu bagian dari seni, dimana seni itu menunjukan pada sebuah bentuk dari seni dalam mengungkap pengalaman dan perasaan seorang yang mempunyai kemampuan untuk mengekspresi yang disebut dengan seorang pelukis atau seniman pada umumnya.

Seni lukis membuat setiap orang menghargai sebuah perbedaan, karena perbedaan dalam seni lukis menjadi bagian yang harus dihargai. Demikian juga perbedaan dalam realitas sosial budaya dan agama menjadi warna kehidupan manusia, untuk mencapai kesempurnaan. Karena Allah sendiri menciptakan manusia dalam bersuku bangsa untuk saling mengenal.

Untuk itu seni lukis sebagai sebuah media yang kuat itu membangun kesadaran manusia dalam mempersepsikan diri terhadapan realitas kehidupan ini. Sebagai bentuk pernyataan diri manusia berada dalam realitas kehidupan.

W. Stanley Taft dan James W. Mayer menyatakan sebuah lukisan menyajikan gambaran yang mewakili hal-hal yang tampak, ide-ide, atau peristiwa sehari-hari atau barangkali yang tidak memiliki hubungan langsung dengan pengalaman kita sendiri. Dalam hal ini, kita sering terinspirasi, mendapatkan pengalaman informasi, dan diberikan kesenangan dengan apa yang kita lihat (I Gede Arya Sucitra, 2013: 5).

Membuat seni mempunyai banyak pandangan dan pengertian dari para filosof, budayawan, seniman sendiri dan kritikus seni, untuk itu kita membicarakan seni, dari berbagai pandangan dengan pengertiannya.

Ki Hajar Dewantara menjelaskan seni sebagai segala perbuatan manusia yang timbul dari kehidupan perasaannya dan bersifat indah, sehingga dapat menggerakan jiwa perasaan manusia. 
Sedangkan menurut Soedarso Sp, seni adalah karya manusia yang mengkomsumsikan pengalaman batin; pengalaman batin tersebut disajikan sehingga merangsang timbulnya pengalaman batin pula pada manusia lain yang menghayatinya.

Kelahirannya tidak didorong oleh hasrat memenuhi kebutuhan pokok, melainkan merupakan usaha melengkapi dan menyempurnakan derajat manusia dalam memenuhi kebutuhan spiritual.

Dari pandangan para pengamat seni rupa, bisa dilihat bahwa berbicara mengenai gagasan dan konsep seni lukis. Bisa dilihat sebagai pemahaman pengetahuan dan teknik melukis, sebagai ekspresikan diri, dalam sebuah karya seni lukis.

Namun dalam pengetahuan seni, konsep seni lukis sebagai ekspresi dan tanda dari karya lukisan. Dari seorang pelukis yang melihat realitas sosial budaya dalam menterjemahkan sebagai bentuk karya lukisan dalam bidang dasar. Kemampuan teknik banyak gaya dalam melukis, maupun merepresentasikan karya seni lukis. Merupakan sebagai sebuah metode di dalam membuat karya seni lukis.

\section{e. Pengetahuan Seni Lukis}

Rosalind Ragans menjelaskan seni lukis sebagai pengetahuan sejarah lukisan dan pemahaman mendalam terhadap bahan-material yang membentuk sebuah karya seni terutama dalam lukisan menjadi elemen dasar yang penting untuk dimiliki oleh setiap orang yang akan serius menggeluti penciptaan lukisan.

Sebuah lukisan tercipta oleh rangkaian berbagai macam teknik melukis dan bahan-bahan penyusun material seperti kanvas, kertas, kayu, cat, pigmen, binder, medium, hingga varnish. Seperti media dalam menggambar, ada banyak jenis media lukisan, masing-masing hadir dengan kualitasnya yang unik. Seniman 
Dengan kreativitas akan mempermudah kita di dalam menghadapi permasalahan dan hambatan di dalam berkarya. Misalnya kalu kita tidak ada gagasan, tidak ada inspisrasi atau mengalami kejenuhan, kebosanan atau kebuntuan dalam berkarya sehingga permasalahan ini harus diatasi secara lebih tepat.

Untuk itu di dalam memahami tahapan berkarya seni lukis adalah salah satu penyelesaian yang dapat memberikan alternatif bagi proses berkarya. Kreativitas seorang pelukis dalam membuat karya seni tidak lagi mengalami kejenuhan, kebosanan atau kebuntuan membuat kita kehilangan orientasi kesenian yang telah ditetapkan sebagai sebuah pemahaman kita di dalam dunia seni.

Dengan menyadari tahapan seni lukis merupakan cara untuk memposisikan kita dalam berkarya. Yaitu dalam proses berkarya tidak terpaku pada permasalahan pengetahuan estetika dan seni saja. Begitu juga dalam melihat teknik bukan menjadi factor utama, tetapi menjadi bagian dari proses berkarya.

Membuat karya seni lukis memerlukan persiapan dan tahapan yang akan dilakukan dalam berkarya seni lukis. Tahapan ini pun bisa dibuat sesuai dengan kebutuhan kita masing-masing dalam membuat karya. Dan ini merupakan salah satu yang perlu dibuat tahapan di dalam membuat karya seni lukis :

1. Membuat diskrispsi tentang tema, berbasis realitas sosial budaya, dan teknis pengarapan sampai presentasi, yang diberikan sesuai dengan latar belakang mahasiswa dalam membuat karya lukisan.

2. Mahasiswa mempersiapakan alat melukis berupa cat akrilik, kuas, tempat (palet) pencampuran cat, tempat air kecil untuk mencuci kuas dan tempat air untuk mengencerkan cat, sesuai dengan kebutuhan di dalam melukis dan kanvas sesuai dengan ukuran yang telah ditentukan. Begitu dengan mempergunakan media lainnya. 
3. Tersedianya palet sebagai tempat cat dan mencampur cat sebelum sapuan kuas memenuhi bentuk atau bidang kanvas, sebagai karya seni lukis yang dibuatnnya.

4. Di studio lukis disediakan eksel untuk meletakan kanvas ketika melukis. Celemek untuk melindung baju agar tidak mengenai cat ketika sedang melukis. Penataan ruang dan pencahayaan yang memadai di dalam melukis. Agar bisa mendukung proses berkarya seni lukis lebih baik dan mendukungnya.

5. Melukis tema dengan membuat sketsa dikertas, fotografi, media cetak, internet dan menghadirkan obyek itu secara langsung. Sebagai obyek lukisan yang ingin dibuat di atas bidang kanvas.

6. Melukis bisa dengan membuat sketsa di atas kanvas dan mengisi warna sehingga menghasilkan bentuk. Membuat warna dasar di atas kanvas, membuat sapuan sebagai bentuk awal yang kemudian dilanjutkan dengan sapuan berikutnya sehingga terbentuklah obyek lukisan. Sampai tahap detail dan penyempurnaan dari karya seni lukis, sehingga dianggap selesai sebagai karya lukisan.

7. Setelah bentuk obyek secara keseluruhan telah terbentuk dengan baik. Maka diadakan penyempurnaan dengan warna yang lebih halus, kasar atau ekspresi. Sesuai dengan gaya lukisan yang digarapnya. Sebagai wujud dari representasi seorang pelukis dari sebuah gagasan dan konsep berkeseniannya.

8. Karya lukisan dinyatakan sudah selesai atau belum, ditandai dengan membumbui tanda tangan atau nama pembuat karya lukisan itu. Di atas lukisan yang dianggap sudah selesai.

9. Mampu menjelaskan karya lukisan yang dibuatnya; mulai dari ide, proses berkarya dan karya merepresentasikan dari tema 
gagasannya. Dengan metode mimes, riset, pengembangan dan interpretasi.

10. Mampu memamerkan hasil karya lukisan selama satu semester di ruang pameran, sesuai dengan kaidah pameran pada umumnya. Dengan membuat rancangan display pameran, agar mencapai sasaran dari karya yang dipamerkannya. Membuat tulisan konsep berkarya untuk dikirim ke media cetak dan elektornik, spanduk, katalog, keterangan judul karya.

11. Mampu presentasikan gagasan dan kreativitas, serta proses berkarya selama satu semester. Sebagai bentuk refleksi seorang pelukis terhadap proses berkarya seni lukis. Untuk lebih berkembangan dan lebih baik dalam melihat permasalahan realitas sosial budaya. Serta menginterpretasikan tema lukisan yang dapat memberikan pandangan yang visioner.

Dalam pembelajaran ini lebih melihat permasalahan menjadi lebih luas berkaitan dengan seni lukis. Bahwa dalam proses pembuatan seni lukis dengan tahapan yang telah mencapai apa yang dilakukan, dalam berkarya seni lukis.

Sebagai sebuah peningkatan dari proses berkarya seni lukis dalam mewujudkan gagasan dan kreativitas dalam kemampuan tekniknya. Begitu juga bagaimana bisa melihat rangkaian gagasan dan kreativitas serta kemampuan teknik itu memadukan dalam mengembangkan kemampuan pengetahuan berkeseniannya.

Berkaitan dengan masalah realitas sosial budaya memberikan kemungkinan pada pemahaman terhadap kesadaran dalam melihat karya seni lukis sebagai kekuatan dalam menangkapnya. Untuk itu perlu dilihat sejauh mana karya seni lukis itu 
mempunyai keterkaitan dengan karya seni lukis yang menjadi tugas dalam pembelajaran seni lukis.

Realitas sosial budaya menjadi intstrument pembelajaran mengarah pada apa yang ingin dicapai dalam pembelajaran seni lukis. Bahwa dengan belajar seni lukis bukan hanya bisa melukis dengan baik, sesuai dengan tahapan pembelajaran.

Tapi juga dengan belajar melukis seseorang atau mahasiswa dapat memahami dan mempunyai kesadaran tentang kehidupan sosial masyarakat dengan kehidupan budayanya.

Bukan itu saja dengan pembelajaran berbasis sosial belajar seni lukis mendapat nilai keyakinan hidup untuk bisa diartikulasikan dalam kehidupannya. Seni lukis bisa menyatu dengan kehidupan masyarakat sosial, sebagai bagian dari budaya.

Seni lukis memberikan pemahaman dan pengertian yang lebih luas dari karya seni lukis. Pemahaman konsep gagasan seni lukis, itu dasar dari tahapan melukis.

Konsep gagasan mempunyai pemahaman lebih luas sebagai pandangan hidup, sikap dan keyakinan seorang pelukis. Yang membuka pandangan luas terhadap realitas sosial budaya sebagai nilai yang sublim dan spiritual dalam masyarakat. Jadi konsep gagasan bukan sekedar dari kebutuhan berkarya. Tapi itu memang menjadi pertumbuhan seorang pelukis di dalam kehidupannnya.

Konsep kreativitas juga bukan saja berkaitan dengan teknis dalam berkarya. Tapi memang sesuatu yang tumbuh dalam diri seorang pelukis dalam seni yang berkaitan dengan nilai realitas sosial budaya sebagai sebuah nilai yang sublim dan spritualitas yang mengacu pada nilai agama.

Pemahaman kreativitas, sebagai kesadaran seorang pelukis yang berpikir secara teratur, sampai dengan berpikir yang imajinatif. Paduan untuk menemukan elemen seni lukis, seni rupa 
ekspresi dengan mentransformasi bentuk, material yang diolah menjadi karya seni transedental.

Proses ini bisa terjadi karena peranan gagasan sebagai dasar dari kreativitas di dalam berkarya. Memberikan perspektif permasalahan dan subject matter yang diungkapkan dalam karya seni, menjadi sebuah kesadaran tentang permasalahan yang dihadapi setiap orang. Baik itu permasalahan kehidupan manusia pada umumnya, maupun masalah sosial, alam benda maupun dengan alam itu sendiri, secara khusus.

Sedangkan konsep seni hanya sebagai pengetahuan, karena dalam teori estetika yang kita pahami, hendaknya didudukkan pada tataran pengetahuan yang sifatnya memberikan wawasan seni saja.

Mengantarkan kita pada proses kreatif yang jauh lebih berkembang dari apa yang kita pahami. Bukan sebagai batasan yang membuat kita kehilangan kreativitas di dalam berkesenian.

Membangun kesadaran di dalam seorang pelukis, bahwa melukis bukan terpisah dari aspek di luar seni lukis. Tetapi menjadi satu kesatuan tanpa harus mengorbankan seni dalam membuat karya seni.

Bukan itu saja kita menjadi takut melakukan sesuatu, untuk berkarya seni. Bila seorang pelukis tidak bisa menempatkan diri pada dunia seni, terpaku pada bentuk seni. Kita tidak bebas lagi untuk mengeksplorasi gagasan, menjadi suatu karya seni yang berbicara. Tanpa harus mengikuti atau dibatasi teori estetika dan seni.

Dapat melukis dengan gagasan dengan tahapan berkarya seni lukis yang baik. Melahirkan kemampuan teknik dalam berkarya seni lukis berbasis realitas sosial budaya. Kemampuan melukis bagi seorang pelukis menjadi terkontrol tanpa membatasi kreativitas berkarya. Selain mengembangkan kemampuan teknik 
melukis, juga mengembangkan ide dan gagasan dalam berbagai media yang lebih beragam lagi.

Ide dan gagasan mampu mengembangkan teknik melukis dengan berbagai media, sehingga mampu melihat berbagai media sebagai sebuah gagasan dan kreativitas berkarya, tidak terikat pada bentuk atau materi.

Kemampuan teknik dan kaya gagasan menumbuhkan khazana kehidupan seorang pelukis. Dengan seni lukis media dalam dunia seni, sebagai sarana dialogis dengan realitas sosial budaya dengan kehidupan masyarakat. Peranannya memberikan kontribusi pada reallitas sosial budaya masyarakatnya.

\section{Karya Seni Lukis}

Seni lukis salah media dua dimensi yang menjadi media ekspresi seorang seniman dalam mengungkapkan ide dan gagasan yang dilatar belakang dengan realitas sosial budaya, di mana dia dilahirkan dan dibesar sebagai seorang yang mempunyai nilai budaya dibawanya sebagai sebuah kehidupannya.

Seni lukis sebagai sebuah gambaran realitas dari seorang seniman terhadap realitas sosial budaya di mana masyarakat tumbuh dan berkembang. Gambaran ini menjadi sebuah kesadaran seorang seniman, untuk dapat menginspirasikan, memberikan gambaran sebuah sejarah, sejarah sedang berlangsung, sejarah masa depan dalam kehidupan sosial budaya yang akan datang.

Seorang seniman bisa memprediksi sebuah kehidupan masyarakat dalam realitas sosial budaya masa akan datang. Kesadaran terhadap realitas sosial budaya ini menjadi sebuah tanggung jawab seorang seniman.

Dengan demikian teknik melukisnya bisa dikembangkan menjadi kreativitas yang lebih baik, sebagai bentuk sumbangsih pada dunia seni lukis. Mengembangkan realitas sosial budaya 
masyarakat, karena memberikan pencerahan dan inspirasi. Dalam bentuk yang sangat mudah dikenalkan tapi mempunyai kemampuan teknik yang baik.

Gagasan dalam karya seni sangat terlihat dengan baik. Paduan antara gagasan serta teknik berkarya dengan baik, memberikan hasil karya yang baik. Meski dengan media yang sangat sederhana.

Gagasan dan kemampuan berkarya seni itu memberikan konstribusi pada kehidupan masyarakat yang berkaitan dengan sebuah pemikiran dan inspirasi untuk membangun kesadaran masyarakat terhadap lingkungan dan kehidupan realitas sosial budayanya. Dengan demikian menumbuhkan sikap hidup masyarakat dan mahasiswa dalam kesadaran pada nilai kehidupan yang berkaitan dengan nilai etika, moral dan agama.

Spiritualitas masyarakat menjadikan kehidupan masyarakat adil dan sejahteraan. Sebagai sikap bangsa yang berbudaya dan beradab, di mana sikap tolerasi dan gotong royong.

Kemampuan berkarya bukan semata-mata sebuah keterampilan bagi mahasiswa. Tapi sebagai sebuah pengembangan pengetahuan seni dari aspek realitas sosial budaya yang ada di dalam kehidupan masyarakatnya.

Kemampuan menguasai elemen seni rupa, membuat teknik melukis menjadi representasikan gagasan realitas sosial budaya, dalam seni lukis. Dengan demikian kemampuan pengetahuan realitas sosial budaya di dalam berkarya bisa berkembang.

Memberikan inspirasi untuk berkreativitas di dalam berkarya, sehingga tidak terpaku pada kemampuan teknis saja. Tapi menjadi stimulasi diri seorang pelukis, mahasiswa untuk mengolah jiwa dan rasa, sehingga memperkaya realitas sosial budaya di dalam kehidupan masyarakatnya. Kreativitas selalu menjadi 
kekuatan di dalam proses berkarya seni lukis untuk dapat menangkap persoalan dengan baik.

Kemampuan melihat elemen seni rupa memberikan teknik dalam berkarya, bisa dilakukan dengan mengadakan latihanan, membuat karya seni lukis. Berkarya seni lukis berangkat dari teknik dan penguasaan bentuk, bergerak pada pengeksplorasi bentuk sebagai gagasan.

Dengan demikian bentuk dan teknik itu membuka permasalahan yang lebih menarik dengan sapuan kuas menarik cat dalam berbagai bidang dan pengembangan. Memberikan warna dan karakter setiap orang untuk bisa mengembangkan diri sesuai dengan latar belakang kehidupan yang ada dalam kehidupan. Berangkat dari sebuah pengalaman dan yang dialami, sehingga memberikan keinginan dalam mengembangkan aspek kehidupan, dalam hal ini kehidupan realitas sosial budaya. Menjadi bagian dari kehidupan masyarakat yang mampu mengembangkan budi luhur sebagai bangsa di dalam kehidupan sosial budaya masyarakatnya.

Sebagai sebuah kesadaran seorang pelukis, seniman dalam melibatkan diri pada permasalahan kehidupan realitas sosial budaya di mana dia berada. Sebagai bentuk partisipatoris dalam berkesenian.

Hal itu akan memberikan kesadaran masyarakat dalam kehidupan. Untuk bisa hidup lebih baik dengan melakukan kegiatan yang bersifat memberikan kesadaran dan peran dalam kehidupan sebagai pribadi maupun sebagai anggota masyarakat dan bangsa.

Bukan itu saja mampu membuat karya lukisan yang baik, tetapi juga mampu menjelaskan proses berkarya seni lukis. Bagaimana membuat karya seni lukis ini dengan baik. Dengan menjelaskan tahap-tahpan berkarya seni lukis. Begitu juga bisa membuat lukisan yang didasarkan gagasan realitas sosial budaya. 
Dan satu lagi juga berkembangnya teknik seni lukis, dari perkembangan teknologi dan informasi yang ada di dalam kehidupan masyarakatnya. Dengan demikian karya lukisan sesuai dengan tema realitas sosial budaya dalam teknik yang diungkapkan.

Di dalam pembelajaran konsep seni rupa sebagai elemen seni lukis. Membuat seorang pelukis dapat melihat seni lukis sebagai gagasan dan kreativitas. Bahwa melukis menjadi pandangan berpikir dan merasakan dalam realitas sosial budaya. Pengetahuan, konsep berkarya, dan memahami teknik, menjadi bagian penting dalam mengungkapkan gagasan menjadi karya seni lukis.

Teknik bagi seorang pelukis menjadi bagian dari kehidupan, artinya teknik sudah terinternalisasi kedalam dirinya, sehingga teknik membantu untuk mengungkapkan gagasan di dalam melukis. Teknik menjadi bagian dari seni lukis itu berkembang sesuai dengan perkembangan gagasan di mana karya seni lukis itu lahir dan berkembang sesuai dengan tema sosial budaya yang diungkapkan.

Konsep dasar seni rupa dalam seni lukis mendasari perkembangan selanjutnya. Sebagai elemen seni rupa yang dikembangkan secara berkala, sejalan dengan perkembangan dalam berkarya seni lukis. Yang dilakukan oleh seorang pelukis dalam membuat karya.

\section{Contoh Karya}

Contoh Karya yang dibuat oleh mahasiswa dalam mempresentasi tugas karya seni lukis. Sebagai tahapan dari sebuah pembelajaran dari membuat karya seni lukis. Dengan memakai landasan dari konsep seni rupa yang telah menjadi media didalam melukis. 
Diharapkan menjadi kesadaran dan pengetahuan bahwa karya seni lukis, cakupan dalam pengetahuan seni rupa. Untuk dipergunakan dalam membuat karya seni lukis yang lebih menekankan pada konseptual dan metodologi di dalam membuat karya seni lukis. 


\section{Glosarium}

Bentuk Biomorfis : Sebagai bentuk anatomi yang mem-berikan bentuk alamiah lebih mengalir dan mengalun, sehingga terlihat organis bentuk yang lembut, melengkung dan terlihat dinamis, fleksibel.

Bentuk Geometris : Sebagai bentuk yang terstruktur, terukur, teratur dan tepat dalam konstruksi bentuk yang kaku dan tegas

Konsep dasar seni lukis : Sebagai awal keberangkatan dalam berkarya dengan memperhatikan masalah media dan teknik berkarya.

Pengetahuan Seni : Sebagai penentuan dari sebuah karya seni atau bukan

Teori : pokok pertama/utama yang mendasari keseluruhan pemikiran. Konsep biasanya hanya ada dalam pikiran atau kadangkadang tertulis secara singkat. Dalam penyusunan ilmu pengetahuan diperlukan kemampuan menyusun teori dasar yang dapat diuraikan terus menerus, kemampuan abstrak (menyusun kesimpulan) tersebut dinamakan pemikiran konseptual.

Subyect matter : Tema permasalahan dari sebuah karya seni lukis 


\section{DAFTAR PUSTAKA}

1. Miranda, J. Burler. 2003. Menggali Kekuatan Intuisi. Jakarta: Cakrawala.

2. Utami, Munandar. 1984. Mengembangkan Bakat Dan Kreatifitas. Jakarta: Gramedia.

3. Yasraf, Piliang Amir. 1998. Sebuah Dunia Yang Dilipat. Bandung: Penerbitan Mizan.

4. Geoffry, Petty. 1997. How To Be A Better At Creativity. London: Kogan Page.

5. Nasbahry, Couto \& Minarsih. 2009. Seni Rupa, Teori dan Aplikasi. Padang Panjang: Penerbit UNP Press.

6. Read, Herbert. 2000. The Meaning Of Art. Terjemah Soedarso SP. Yogyakarta: Penerbit Duta Wacana University Press. 
kebiasaan, tradisi, realitas sosial budaya sudah terbentuk dalam seni lukis itu sendiri.

Materi pembelajaran ini menumbuhkan kesadaran seni lukis. Untuk dapat melihat karya seni lukis sebagai bagian dari kehidupan realitas sosial budaya. Sebagai representasi dari seorang pelukis, seniman di dalam kehidupan realitas sosial budaya, di mana dia berada. Membangun kesadaran pelukis pada masalah realitas sosial budaya. Kehidupan masyarakat adalah realitas yang mempengaruhi seseorang.

Begitupun juga seorang pelukis dengan sendiri akan menangkap kehidupan masyarakat. Menangkap permasalahan sebagai bagian dari kehidupan masyarakat atau sebagai anggota masyarakat.

Untuk bisa melihat seni lukis sebagai bagian dari kehidupan masyarakat di mana mengalami perkembangan dinamika sosial. Sesuai dengan perkembangan masyarakatnya. Pelukis melukiskan dalam bentuk karya seni lukisnya. Sebagai bentuk kepedulian terhadap permasalahan realitas sosial budaya.

Menjelaskan tugas di dalam membuat karya seni lukis itu, berbasis realitas sosial budaya, menumbuhkan kepribadian yang peduli terhadap permasalahan kehidupan sebagai manusia yang mempunyai tanggung jawab pada kehidupan dunia dan akhirat.

\section{Seni Lukis dan Realitas Sosial Budaya}

Seni lukis adalah bagian dari kehidupan realitas sosial budaya manusia, yang selalu memberikan dimensi yang lebih luas dan memberikan pemahaman yang lebih baik sebagai sebuah kesadaran di dalam melihat kehidupan dan permasalahan hidup masyarakatnya.

Seni lukis sebagai bentuk jejaring dari kehidupan realitas sosial budaya dari representasi dari kehidupan seorang pelukis. 
Sebuah realitas obyektif dalam karya lukisan, banyak memberikan kemungkinan dan perkembangan di dalam melihat permasalahan yang dihadapi manusia dalam realitas sosial budayanya. Sebuah interaksi baik secara langsung maupun tidak langsung, seni lukis menjadi konstelasi dari perkembangan realitas sosial budaya.

Dengan demikian pertumbuhan seni lukis dan perkembangan realitas sosial budaya masyarakarat saling berinteraksi. Bentuk dialogis yang menjadi kesinambungan dari perkembangan seni lukis. Baik dari aspek pemahaman dan pemikiran, aspek bentuk dan keindahan, aspek media dan perkembangan teknologi informasi. Membuat karya seni lukis menjadi realitas sosial budaya.

Karena seni lukis itu memang sudah menjadi fitrah manusia yang selalu menyukai keindahan. Menjadi jati diri manusia yang menghayati nilai keindahan, kebaikan dan kebenaran. Sebagai sebuah keyakinan beragama, yang melingkupi kehidupan dunia dan akhirat. Membuat karya seni lukis tidak dalam dipengertian yang terbatas, karena dilihat sebagai karya seni dari sebuah bentuk lukisan.

Keindahan lukisan juga yang membawa kesadaran masyarakat dalam realitas sosial budaya akan meningkat. Menjadi sebuah peradaban bangsa yang menghargai nilai - nilai tradisi dan budaya yang mendasari dari sebuah perkembangan masyarakat. Dengan demikian akan memberikan warna tradisi

Agama melukiskan kekuatan imajinasi manusia untuk membangun gambaran realitas. Seni Islam diilhami oleh spiritualitas Islam secara langsung, sedangkan wujud dibentuk oleh karakteristik tertentu dari tempat penerima wahyu Al Qur'an, yaitu dunia Semit dan nomadis yang nilai-nilai positifnya diuniversalkan Islam. Akan tetapi, bentuk wahyu Islam tidak mengurangi kebenaran bahwa sumber seni berasal dari kadungan batin dan dimensi spiritual Islam (Dadan Rusmana, 2014; 52). 
Keindahan adalah manifestasi dari nilai hakiki dari Sang Pencipta. Karena Allah Maha indah dan menyukai keindahan. Di mana alam semesta diciptakan dengan penuh keindahan dan manusia diciptakan dengan keindahan bentuk dan jiwa yang mengkokohkan bahwa keindahan itu memang menjadi sebuah realitas sosial kehidupan yang ada sebagai sebuah kebenaran.

Menurut Issac Reed dan Jeffrey C. Alexander berdasarkan definisinya, budaya adalah kegiatan intelektual dan artistik serta artefak-artefak yang dihasilkan dari kegiatan ini. Memiliki budaya berarti memiliki untuk menginterpertasikan artefak ini, serta cita rasa untuk membedakan yang bagus dari yang buruk.

Begitu juga mampu menumbuhkan kepedulian seorang pelukis pada orang banyak dalam hal ini rakyat. Dengan melukis mahasiswa mengenal keindahan hidup yang lebih baik, tentang etika berkehidupan. Memberikan nilai yang baik dalam sebuah karya seni lukisnya, sesuai dengan tingkat dalam pengetahuannya.

Dalam seni, manusia menggunakan bahan dan energi dari alam untuk mengembangkan kehidupan. Seni adalah bukti bahwa manusia secara sadar dapat mengembalikan persatuan sensasi, kebutuhan, dan tindakan ditemukan dalam kehidupan hewan.

Kesadaran menambahkan regulasi, seleksi dan variasi untuk proses ini. Gagasan seni, maka, prestasi kemanusiaan terbesar. Bangsa Yunani membedakan perintah dari materi, dan manusia dari seluruh alam, dengan cara seni. Seni, bagi mereka, adalah cita-cita membimbing bagi umat manusia.

\section{Definisi Realitas}

Realitas menurut Chris Barker mengacu pada pengertian realisme yang artinya sesuai dengan kenyataan. Realisme secara epistemologis yang menyatakan bahwa kebenaran adalah sesuatu yang bersesuai dengan atau menggambarkan kenyataan. 
Dalam karya seni lukis realitas adalah sebuah kenyataaan dimana kenyataan itu adalah sebuah keberadaan seorang pelukis di dalam kehidupannya. Menurut Rathus karya realisme mengacu kepada penggambaran manusia dan benda sebagaimana ia melihat dengan mata atau dipikirkan, tanpa idealisasi, tanpa distorsi.

Realitas dalam seni lukis adalah menggambarkan realitas obyektif dari obyek yang dilukis oleh seorang pelukis. Tanpa ada perubahan bentuk, warna yang menjadi bagian dari obyek yang dilukiskan.

Begitu juga dengan apa yang dibuat dalam sebuah lukisannya adalah obyektifitas dari kenyataan yang dilihat menjadi obyektifitas realitas karya dalam lukisannnya. Hal ini memperlihatkan bahwa realitas yang ada berada dalam dua posisi yang bisa dilihat; kenyataan seorang pelukisan dalan realitasnya, dan kenyataan obyek lukisan yang dilukisannya ada dalam realitas seorang pelukis. Bisa menjadi obyek yang ada dekat dengan pelukisnya, dan obyek itu menjadi realitas karya lukisannya yang dibuatnya.

Membuat realitas berusaha untuk melihat lebih dari pada apa yang dilihat. Bahwa selain dapat membuat, juga menganalisa, merenungkan dan menyatakan dalam sebuah karya lukisan, sehingga dapat memperoleh perspektif filosofis yang jernih tentang apa yang dilakukan dengan apa yang dilukisnya.

\section{Definisi Sosial}

Sosial dalam bahasa Inggris, Society yang berarti sekelompok individu yang disatukan oleh seperangkat perbedaan dan seperangkat sistem hubungan normatif, yang tindakan memicu respons yang khas pada yang lainnya. Menjadi bagian dari masyarakat yang sama berarti tunduk pada norma interaksi ini. 
Pengertian sosial yang berkaitan dengan teori sosial maka akan mengacu pada beberapa pemikiran. Untuk dapat melihat kerangka pemikiran mengenai pengertian dari sosial. Setiap pemikiran sosial meskipun berbeda, tetapi ada satu kesamaan yang berkaitan dengan sosial. Diantaranya adalah Max Weber yang menjelaskan sebagai ilmu sosial dan penelitian sosial.

Max Weber menyatakan "bahwa sosiologi adalah ilmu tentang dirinya dengan pemahaman interpretasi aksi sosial dan karenanya dengan penjelasan penyebab saja dan konsekuensinya". Dalam tulisan-tulisan lain, Weber memperluas lebih lanjut tentang definisi tentang sosiologi dan sosial, tetapi perlu dicatat bagaimana definisi singkat ini merangkum pendekatan untuk mempelajari masyarakat.

Berbeda dengan pengertian sosialisme yang berusaha menghindari dari implikasi totalitarian dan komunisme, dan bekerja efektif dalam konstitusi demokrasi liberal. Dalam perkembangan politik di Indonesia sosialisme oleh komunis PKI menjadi sebuah langkah gerakan yang berkaitan dengan ideologi.

Dengan begitu komunisme di Indonesia menyatukan sosialisme dengan komunisme, yang mempunyai pengertian masyarakat komunis. Pada hal sosialisme mengacu pada konstitusi demokasi liberal yang juga tidak sesuai dengan kaidah dari ideologi Pancasila.

Namun sosial dalam berkesenian ini berkaitan keberadaaan seorang pelukisan dalam kehidupan masyarakat yang beraneka ragam suku bangsa dan agama. Melingkupi kehidupan realitas sosial budaya masyarakat, dimana seni lukis itu tumbuh dan berkembangan.

Sebagai kepribadian budaya yang bhineka tunggal ika menjadi satu kesatuan di dalam dirinya, sehingga karya lukisan yang dilahirkan pada realitas sosial budaya seorang pelukis. 
Kesadaran ini perlu disadari dalam berkesenian dan berkarya seni, agar tidak terpaku pada masalah bentuk dan teknis tidak menghambat gagasan dan kreativitas dalam proses berkarya seni lukis.

\section{Definisi Budaya}

Menurut Raymond Williams, pengamat dan kritikus kebudayaan, melihat budaya (culture) dalam bahasa Inggris mempunyai kompleksitas pengunaannya.

Budaya bisa disama dengan kutivasi (cultivation) yang mempunyai pengertian pemeliharaan ternak, hasil bumi dan upacara sebagai bentuk kultus atau "cult" Begitu juga budaya mengacu padanan dari kata peradaban (civilization) sebagai gambaran masyarakat atau bangsa secara menyeluruh.

Hal ini yang dijelaskan juga oleh S. Takdir Alisyaban seorang budayawan, "Perhubungan antara budi dan budidaya ini membuat filsafat budi dan kebudayaan ini sepenuhnya filsafat Indonesia. Dalam bahasa Inggris tak ada perhubungan antara budi, yaitu mind dengan culture.

Sebab itu definisi kebudayaan dalam bahasa Inggris sangat kabur, malahan kacau. Culture sering didefinisikan sebagai way of life dan merupakan fenomena masyarakat, sehingga ilmu-ilmu kelakukan manusia sebagai mahluk budi dan kebudian disebut social sciences. Kalau masyarakat yang menentukan kelakuan kebudayaan, tentu hewan juga harus berkebudayaan, sebab hewanpun hidup bermasyarakat.

Demikian juga hewanpun mempunyai way of life, tetapi tidak mempunyai kebudayaan. Pengertian culture ini lebih kacau lagi apabila kita ingat, bahwa Toynbee hanya memakai perkataan civilization. Perkataan culture hanya terbentuk buat kebudayaan primitive.. . 
Inilah yang terlihat dan dirasakan di dalam sosiologi estetika, bahwa keindahan itu menjadi sebuah kasta, ada Kasta Brahmana yang direpresentasi pada institusi seni, Kasta Satria yang direpresentasi oleh para penguasa negara dan pemerintahan. Kasta Waisya yang direpresentasikan oleh para kapitalisme, sedangkan Kasta Sudra yang direpresentasikan pada rakyat kecil.

Karena pendekatan keindahan yang dipahami di dalam realitas kehidupan sosial masyarakat yang mengacuh pada pengertian keindahan seni sebagai sesuatu yang bersifat keilmuan dengan pandangan yang mengacuh pada berpikir abstrak, sehingga keindahan seni itu tidak lagi kontekstual.

Begitu juga keindahan seni sebagai sesuatu media yang hanya mengarahkan realitas sosial masyarakatnya, menjadi keindahan seni sebagai panglima politik dari para penguasa. Untuk keindahan seni yang dibentuk oleh sistem yang rapih sehingga cenderung tidak kentara sebagai sebuah kesenjangan yang luar biasa di dalam realitas sosial masyarakat.

Di mana keindahan seni mengarahkan masyarakat pada kehidupan yang berorientasi pada ekonomi yang tak pernah memberikan kepuasan yang sebenarnya, karena keindahan seninya adalah semu. Karena menonjolkan kehidupan hedonisme, hasrat yang tidak pernah terpuaskan.

Untuk itulah sosiologi - budaya seni memberikan pemahaman tentang keindahan seni itu adalah keindahan realitas masyarakat, untuk bisa dipahami sebagai sebuah kesadaran di dalam melihat realitas keindahan sebagai bentuk warna dari kehidupan, di mana warna itu menyadarkan pada manusia di dalam sebuah perbedaan tapi bukan sebuah keterpisahan di dalam kehidupannya.

Untuk bisa dibangun keterkaitan sosial masyarakat di dalam kehidupannya. Sebagai warna warni realitas sosial masyarakat 
yang terlihat harmonis. Berbeda warna yang kemudian dipadu dengan warna lain menjadi lebih indah. Begitu juga kehidupan sosial masyarakat, keindahan seni itu merangkai kehidupan realitas sosial masyarakat yang lebih baik.

Seni, bagi Walter Benjamin, sebagai salah satu ekspresi dari sebuah kebudayaan, bukanlah bagian dari sebuah pandangan dunia, seperti dalam pemahaman Goldman, bukan pula sebuah totalitas seperti dalam pandangan Lukacs, melainkan sebuah fragmen, mikrokosmos.

Seni memiliki basis material di dalam struktur dan organisasi masyarakat, di dalam keyakinan-kenyakinannya, cara-cara produksinya, dan penataan politiknya. Hingga titik ini ide-ide Benjamin sejalan dengan pandangan yang dominan dalam modernisme, yaitu bahwa seni terkait sangat erat dengan landasan produksinya.

Jika seni yang non demokrasi terletak pada aura-aura yang monopolitik, misalnya bahasa-bahasa khas penuturan cerita yang menandai spesialisme-spesialisme dan kepakaran masyarakat borjuis, maka seni sosialis harus didasarkan padak kekuatankekuatan egaliterian kolektif yang dimiliki bersama dalam sebuah masyarakat modern; fakta-fakta realisme.

Karena keindahan seni itu merupakan keterkaitan dengan sebuah bentuk dan warna sosial lainnya, sehingga menjadi sebuah realitas keindahan seni di dalam sosial masyarakatnya.

Karena adanya pemahaman tentang keindahan menjadi sebuah relasi dari kehidupan realitas sosial masyarakatnya. Membuat keindahan seni itu tidak akan terpolarisasikan seperti apa yang sekarang terjadi di dalam kehidupan masyarakat.

Proses pengalaman estetik dengan melakukan pendekatan teori seni yang memperhatikan latar belakang pembuatan karya baik secara psikologi seniman maupun sosiologi lingkungan. Pemasukan latar belakang pembuatan karya pada metode tidak 
lain adalah untuk merumuskan konsep berkesenian yang digunakan olah seniman pada karyanya.

Untuk mendapatkan pengalaman estetik melalui metode ini perlu mengkaji suasana sosial yang terjadi selama karya ini berlangsung, karakteristik berkesenian seniman, kondisi psikologis seniman, kondisi lingkungan baik politik,sosial, budaya, dan ekonomi. Untuk mencapai itu semua perlu dilakukan survey dan wawancara privat dengan Sang Seniman dan keluarga serta teman karib.

\section{d. Seni Lukis Realitas Sosial Budaya}

Seni lukis diformasikan dalam realitas kehidupan sosial budaya masyarakatnya. Sebuah gambaran dari kehidupan yang dikelolah menjadi sebuah bentuk, menyiratkan pandangan dan nilai yang ingin disampaikan dalam karya lukisan tersebut. Seni lukis realitas sosial budaya sebagai norma dan kaidah yang dapat memberikan nilai dan makna kehidupan masyarakatnya. Sebagai sebuah kesadaran dari masyarakat yang mempunyai paduan antara pengetahuan sebuah tata kelola kehidupan, rasa dan sikap menjadi keharmonisan dalam kehidupanan masyarakatnya.

Karya seni lukis menjadi sebuah sirkulasi dari kehidupan budaya masyarakatnya, yang kaya dengan nilai dan pemahaman tentang kehidupan. Di mana nilai kehidupan itu menjadi sebuah representasi dari realitas sosial budaya masyarakatnya sendiri.

Dengan demikian seni lukis menyatukan elemen kehidupan dalam rangkaian keindahan dari karya seni tersebut. Membuat karya seni lukis dapat melakukan pengembangan dalam dunia pendidikan sebagai formasi yang dapat memberikan kontribusi lebih baik. Bahwa seni lukis menjadi nuansa harmoni dalam tata kehidupan realitas sosial budaya. 
Meskipun tidak bisa dipungkiri seni lukis berbasis realitas sosial budaya yang berkembang di masyarakat juga menjadi bagian yang tidak kalah penting meski pengetahuan seni lukis yang berkembang dimasyarakatkan disebut dengan seni tradisi.

Seni lukis itu juga dilihat dari pengetahuan teknik dan media yang dipergunakan oleh masyarakat tertentu. Seperti seni lukis batik, dengan mempergunakan media lilin yang disebut dengan malam, canting sebagai kuasnya, untuk melukis diatas kain. Melukis dengan pola yang telah ditentukan dikenal dengan batik.

Sebuah terminologi batik bukan menyangkut pada bentuk dan media tapi juga filosofinya. Seni lukis sebagai makna kehidupan yang mempunyai akar realitas sosial budaya yang kuat.

Begitu juga dengan seni lukis Bali dengan yang khas dengan mengambil tema keagamaan dan keseharian. Mempergunakan media bambu dengan kain dan warna yang dipergunakan dengan warna alam. Memperlihatkan bahwa seni lukis berkembang pada basis sosial budaya masyarakat setempat.

Untuk itu dalam pembelajaran seni lukis seiring dengan perkembangan zaman, seni lukis yang berkembang dengan baik dari pendidikan seni menciptakan seni lukis formal. Namun di dalam pendidikan formal seni lukis bukan hanya sebagai bentuk formal, belajar pada masalah teknik dan penguasaan bentuk dalam melukis.

Tapi pembelajaran melukis itu lebih jauh menyentuh nilai kemanusian yang mempengaruhi kehidupan seseorang dan realitas sosial budaya dan perkembangan kehidupan sosial. Membuat seni lukis meliputi pemahaman dan pengetahuan tentang nilai kreativitas, spiritual, rasa kemanusian yang tinggi guna membangun tatanan kehidupan sosial masyarakat yang lebih baik. 
Dengan memperhatikan nilai spiritual, sikap dan kepedulian terhadap masalah sosial yang menjadikan semangat moral dan keagamaan untuk memperjuangkan.

Pemahaman ini melihat bahwa seni lukis, seni visual pada umumnya mengajarkan mahasiswa untuk dapat berkarya berangkat dari proyek. Hanya persoalannya harus dilihat dari media apa yang dipergunakan.

Kalau seni lukis dengan media kertas atau kanvas dan cat akrilik di dalam menangkap permasalahan subyek seni lukis, mampu melahirkan kemampuan melihat bentuk obyek pada pemahaman subyektifitas, menurut pandangan mahasiswa.

Bisa juga dengan mempergunakan berbagai teknik agar bisa mengembangkan pemahaman tentang permasalahan nilai, makna sesuatu tema atau obyek. Dengan demikian sensitifitas rasa dan olah jiwa mampu mengembangkan kesadaran diri dalam bersikap, karena menumbuhkan sikap sosial untuk bisa berbagi dengan orang lain.

Tapi bagaimana pemahaman itu bisa didapat memerlukan observasi dengan cara keterlibatan seni dengan permasalahan subyek seni lukis. Mahasiswa sebelum melukis harus beradaptasi di mana dia berada dalam satu tempat untuk mulai melukis.

Dengan beradaptasi diharapkan mahasiswa mampu melukis dengan baik. Sebab melukis bukan hanya menangkap bentuk dari obyek atau figur saja. Tapi bagaimana mampu membangun suasana yang empati pada bentuk atau figur manusia dengan baik.

Dengan demikian bentuk atau figur manusia hanya sebagai media mengungkapan apa yang terjadi pada bentuk itu sendiri. Jadi ketika melukis seorang petani atau nelayan, bukan melukis sosok bentuk fisik dari seorang petani dan nelayan, akan tetapi mampu melihat dan merasakan persoalan ketidak berdayaan petani dan nelayan ternyata seseorang itu bukan sebagai petani 
dan nelayan yang sebenarnnya. Tapi sebagai buruh tani dan nelayan, sebagai petani garap dari tuan tanah atau taouke yang mempunyai perahunya.

Kehalusan dalam seni sebetulnya memberikan setiap orang untuk melihat kehidupannya ini dengan selaras, harmonis untuk mewarnai kehidupan manusia. Hanya karena sistem pendidikan juga melihat kesenian dalam hal ini karya seni lukis hanya sebuah material dan ketrampilan dalam melukis.

Bukan melihat pada bagaimana seni lukis mampu menumbuhkan seseorang menjadi lebih mengerti diri dan kehidupannya, sehingga membawa diri pada empati dan kepedulian terhadap sesama, untuk saling membantu dan menghargai.

Kehalusan dan citra rasa keindahan dalan seni lukis membawa pada kesadaran manusia tentang nilai sublim yang mengantarkan pada nilai tertinggi yang dimiliki oleh agama untuk dihayati dan diamalkan sebagai warna kehidupan yang lebih baik dalam tatanan sosial pada masa sekarang ini.

Pendekatan budaya seni lukis ini selalu memberikan pemahaman pada sebuah hubungan manusia dengan manusia. Dalam satu rangkaian nilai dan makna yang kebaikan pribadi dan kebaikan sosial sebagai nilai. Bukan mengacuh pada nilai agama, meskipun pada saat ini kajian seni dan agama menjadi bagian nilai yang coba dilihat sebagai solusi kehidupan manusia pada saat ini.

Dengan berbagai macam persoalan, namun kalau nilai agama tidak mencapai pada pemahaman konsep ke Esaan Allah SWT dalam hidup ini. Seni lukis dan nilai budaya dengan multikultural tidak berarti apa-apa. Untuk itu seni lukis dalam nilai budaya harus sejalan dengan nilai agama dalam proses kehidupan. 


\section{Glosarium}

Budaya: Menjadi sikap dan pandangan yang diartikulasi dalam nilai agama sebagai prilaku kehidupan suku bangsa. Ketaatan beragama karena kekuatan jiwa sikap terhadap nilai hidup yang diwarnai dengan keindahan karya seni lukis.

Kebudayaan: Manusia menjelma sebagai mahluk yang bebas berpikir, menyelidiki, merasakan dan berfantasi dan berdasarkan sekaliannya, memilih dan mengambil keputusan.

Konsep: Pembelajaran seni lukis sebagai cara berkarya seni lukis dan berpikir tentang seni lukis secara struktur. 


\section{DAFTAR PUSTAKA}

1. Nashori, Fuad. 2002. Mengembangkan Kreativitas Dalam Perpektif Psikologi Islam. Yogyakarta: Penerbit Menara Kudus.

2. Peuresen, C.A.Van. 1976. Strategi Kebudayaan, Yogyakarta: Penerbit Kanisius.

3. Rusmana, Dadan. 2014. Filsafat Semiotika. Bandung: Penerbitan Pustaka Setia.

4. Sutrisno, Mudji dan Hendar Putranto. 2005. Teori-Teori Kebudayaan, Yogyakarta: Penerbit Kanisius.

5. The Oxford Dictionary of Philosophy. 2008. Oxford University Press, edisi bahasa Indonesia, Yogyakarta: Penerbitan Pustaka Pelajar. 


\section{BAB IV \\ MAKNA ALAM BENDA, FIGUR DAN LINGKUNGAN REALITAS SOSIAL BUDAYA}

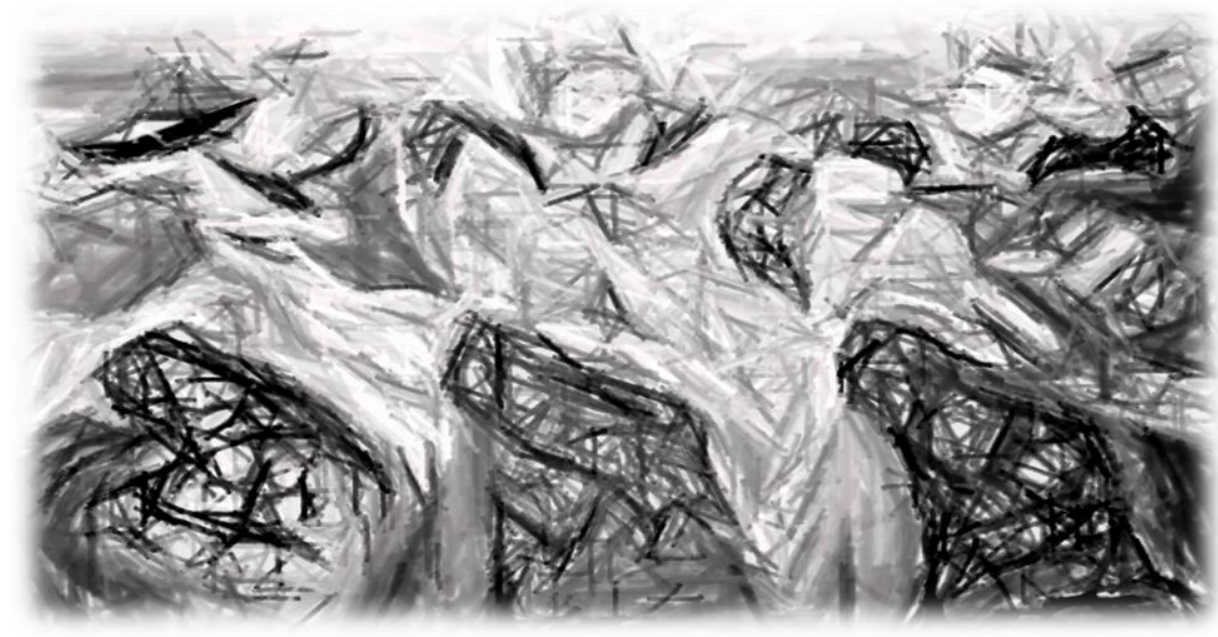

Dealitas sosial budaya sebagai konsep seni lukis dalam membuat karya. Jauh lebih dalam lagi bahwa membuat karya seni lukis sebagai proses pengolah jiwa dan rasa sehingga merasakan apa yang tidak bisa dirasakan oleh setiap orang tapi seorang pelukis bisa merasakan, sehingga bisa menyampaikan dalam karya seni lukisan berkaitan dengan permasalahan realitas sosial yang berkaitan dengan budaya.

Tema alam benda, figur dan lingkungan berbasis realitas sosial budaya. Pembelajaran seni lukis ini menjadi pencapaian untuk mendapat makna yang lebih luas sebagai sebuah karya seni lukis. Dalam perkembangan sebagai sebuah proses seni lukis ini. 
Begitu juga kemampuan berkarya ini menjadi sebagian teknik, tema dan bentuk dari keindahan sebuah karya seni lukis. Bergerak dalam pengembangan diri dengan mengungkapkan gagasan dalam realitas kehidupan. Terlihat bahwa seorang pelukis berkembang pada pemahaman sebagai bagian dari kehidupan. Berkaitan dengan kehidupan sosial masyarakat, di mana budaya menjadi sebuah kekuatan seorang pelukis.

Pembelajaran seni lukis sebagai sebuah konsep dengan menjelaskan sebuah karya seni berangkat dari sebuah tema dan makna, berkaitan dengan realitas sosial budaya.

Untuk bisa melihat realitas sosial budaya manusia di dalam keberadaan, sehingga melahirkan kesadaran berkesenian itu menjadi bagian dari kehidupan manusia. Bahwa seni lukis bukan hanya berkaitan dengan teknik dan ekspresi estetis seorang pelukis.

Memang mengasah jiwa, rasa dan emosi menjadi lebih baik dalam melihat segala permasalahan sosial budaya. Bahwa seni lukis mampu melihat permasalahan realitas sosial budaya itu menjadi lebih jelas, karena pelukis mampu menghadir tema menjadi sesuatu yang baru dan memberikan pencerahan pada diri maupun orang lain. Menjadi tahapan dalam membangun diri setiap orang menjadi lebih baik, berkaitan dengan nilai etika, moral dan agama.

Realitas Sosial Budaya dengan model pembelajaran konstruktivis humanistis mahasiswa menanggapi penjelasan dari tema permasalahan realitas sosial budaya, berkaitan dengan pegalaman hidupnya.

Untuk bisa dikonstruksikan dan dimaknai dalam sebuah karya seni lukis yang dibuatnya. Sedangkan adanya pertanyaan, bisa memperkuat apa yang menjadi permasalahan yang mempunyai kesamaan atau kemiripan di dalam berkarya seni lukis. 


\section{Memaknai Tema Lukisan}

Membuat karya lukis bukan saja melukis apa yang dilihat atau melukis obyek alam benda, figur dan lingkungan realitas sosial budaya; mengambarkan kondisi sosial lingkungan, pemandangan alam dan rumah pakaian dan makanan adat, serta hasil karya seni rupa "tradisi". Tetapi apa yang dirasakan, dialami, dipikirkan dan permasalahan yang terjadi di dalam kehidupan realitas sosial budaya masyarakatnya.

Estetika budaya adalah realisasi tujuan, bertahap dan konsisten dari tradisi spiritual terbaik bangsa, relasi cerdas untuk alam, dan kebangkitan nilai-nilai spiritual bangsa. Estetika Budaya menjadi bagi manusia bukan hanya merupakan persyaratan ideal dan spiritual aktivitas kreatif, tetapi sumber tujuan dan arah untuk kegiatan kreatif.

Semua itu menjadi sebuah obsesi, pergolakan, kegelisahan, pemahaman dan padangan serta pemikiran bahwa karya seni lukis menjadi representasi dari pada yang terjadi di dalam diri seorang pelukis di dalam keterlibatan terhadap kehidupan realitas sosial budaya masyarakat yang ada. Seni itu harus sederhana, sehingga seni itu harus mencari kebaikan dan kesempurnaan. Keduaduanya ini mencari keaslian dalam sifatnya yang universal dan mutlak (menuju keindahan yang mutlak). Keindahan sebagai sesuatu yang lebih baik juga menyenangkan.

Lahirnya karya seni lukis bukan semata membuat obyek yang ada dalam realitas sosial budaya. Tetapi lahirnya seni lukis sebuah perjalan gagasan dan kreativitas seorang pelukis dalam melihat realitas diri dan kehidupan yang berkembang. Untuk dipahami, dipersepsikan sebagai sebuah gagasan di dalam membuat lukisan. Aristoteles berpendapat bahwa karakter-karakter seni harus tampak lebih baik dari kenyataannya, sehingga karena keindahannya yang luar biasa seolah-olah tidak nyata. 
Sebagai upaya menangkap dan memahami realitas sosial budaya dalam satu pandangan tentang seni lukis. Kemudian bisa berkembangan menjadi sebuah realitas pengetahuan seni dan berkembangannya seni sesuai dengan perkembangan zaman.

Namun ada kalanya karya seni lukis mungkin lebih dahulu dalam melihat realitas sosial budaya yang ada di masyarakatnya. Sehingga karya seni lukis belum bisa diterima dengan begitu saja oleh masyarakat. Hal dikarena masyarakat berada dalam lingkung yang terbatas pada kaidah dan pemahaman kolektif.

Sedangkan seorang pelukis menangkap lingkungan dan kaidah yang ada di dalam kehidupan masyarakat menjadi sebuah pemahaman yang memberikan lompat gagasan tentang realitas sosial budaya masyarakatnya. Karya seni sebagai mental objek ideal bersama dengan segala sesuatu yang lain, terjalin erat sebagai umpan balik positif antara intuitif dan kapasitas teknis praktis untuk memanipulasi kuas, cat campuran.

Menjadi karya lukisan yang mirip dengan obyek yang ada dan terlihat estetika. Tapi lahirnya karya lukisan sebagai proses pemaknaan obyek lukisan dalam sebuah karya lukisan. Hal itu terlihat dari cara pandang obyek lukisan, bentuk, komposisi, warna dan ada reduksi obyek lukisan itu.

Sebagai bentuk paduan antara gagasan berpikir seorang pelukis dalam melihat obyek realitas sosial budaya yang ingin dibuat dalam bentuk keindahan lukisan. Membuat obyek lukisan mengalami perubahan dalam segi bentuk, komposisi, sudut pandang yang berkaitan dengan apa yang dipikirkan dan dirasakan oleh seorang pelukis. Sebagai sebuah karya seni lukis yang mengandung nilai keindahan dari karya seni.

Ide estetika, yang mencerminkan pemikiran dan perasaan dari sebuah ide rasional dari karya seni, mampu mengekspresikan masalah dan realitas kehidupan sosial budaya. Mengantarkan 
gagasan karya seni pada nilai estetika tinggi. Imanuel Kant sendiri percaya bahwa karya-karya yang punya kekayaan estetika tinggi tidak lepas dari keterikatan dengan pengalaman spiritual relegius. Kant menunjukkan "kesatuan yang utuh dari sebuah kekayaan pemikiran yang tak terkatakan." bahwa mereka diproduksi dengan cara imajinasi "memproyeksikan sejumlah besar pikiran satu sama lain."

Intensitas aspek keindahan karya seni memiliki implikasi yang jauh lebih luas dengan pertimbangan bahwa karya seni merupakan hasil kreativitas manusia, dalam hubungan ini subyek kreator. Artinya peranan seniman disatu pihak, peranan penanggap di pihak yang lain pada gilirannya menampilkan hubungan yang lebih bermakna apabila dibandingkan dengan keindahan alam. Oleh karena itulah, dalam pengertian yang lebih luas keindahan dikaitkan dengan karya seni yang berfungsi untuk meningkatkan kehidupan masyarakat. Aspek-aspek keindahan alam dengan sendirinya merupakan manifestasi Sang Maha Pencipta, yang secara keseluruhan justru merupakan teladan bagi para seniman ( Nyoman Kutha Ratna 2007:31)

Menurut Plato, keindahan hanya terkandung dalam dunia ide-ide, dunia yang mengatasi kenyataan, yang tidak secara langsung terjangkau oleh pemikiran manusia. Sedangkan menurut Arsitoteles, keindahan sebagai bentuk katarsis, bentuk penyucian diri di dalam mengatasi kenyataan tersebut. Bahwa keindahan sebuah karya seni memberikan makna pada sebuah pemahaman yang lebih mulia tentang bentuk yang merepresentasi kan gagasan.

Penilaian keindahan di alam sesuai dengan kerangka berpikir. Kedua jenis penilaian adalah pertama didasarkan penilaian rasa, keduanya didasarkan pada bentuk pengalaman mental yang didasarkan pada kebebasan bermain bersifat 
harmonis imajinasi dan pemahaman. Pemahaman ini memenuhi tuntutan rasa; kenikmatan estetika muncul dari bentuk pengalaman subjektif dan tidak terlibat dengan kepentingan moral atau empiris. Ketika subyek mencerminkan pada sumber kesenangan mereka, mereka akan menghubungkannya dengan pengalaman yang objek tertentu, dan kemudian penilaian dengan suara "universal" bahwa objek itu indah.

Karya seni lukis terbentuk karena memunculkan suasana gagasan seorang seniman dengan realitas sosial budaya masyarakatnya. Sebagai bentuk kemulian dari sebuah pandangan dan keindahanan hidup yang ditangkap dan dirasakan.

Meskipun masalah itu terasa pahit, menyedihkan, menyakitkan dan sebaliknya sebagai ungkapkan kebahagian, kesenangan serta keinginan untuk memberikan sesuatu pada orang lain melalui karya lukisan. Karena karya lukisan bukan lagi apa yang dilihat oleh orang lain pada umumnya tapi sebuah realitas sosial budaya yang telah mengalami pemaknaan bentuk melalui keindahan dari karya seni. Menurut Aristoteles, seni merupakan tiruan dari alam, tetapi sebenarnya di luar dari alam. Ciri khas seni adalah mengupas alam dari hakekat yang sebenarnya. Menurunkan manusia atau meninggikannya, dan ia merupakan imitasi.

Bahwa di dalam melihat karya seni lukis bukan pada aspek gagasan, tema dalam bentuknya, tetapi juga ada aspek keindahan dari "bentuk" karya seni yang merepresentasikan keindahan dari karya seni lukis. Bentuk keindahan dari karya seni mempunyai pemahaman yang luas di dalam karya seni.

Socrates berpendapat bahwa keindahan dapat dijelmakan melalui gerakan-gerakan tangan. Dengan gerakan tangan dapat ditembus sifat-sifat keragaan, sehingga dapat diperoleh keindahan yang bersifat kejiwaan. Menurut Socrates raga hanyalah 
pembungkus keindahan; keindahan yang sejati ada dalam kejiwaan.

Bahwa keindahan itu melandasi dari perkembangan seni lukis dari arti yang lebih luas lagi. Keindahan bentuk dibagi menjadi empat bagian, pertama keindahan bentuk sebagai bentuk yang indah. Kedua keindahan bentuk itu dari representasi keindahan gagasan, sehingga keindahan bentuk gagasan lebih menonjol dibandingkan bentuk. Ketiga keindahan bentuk rasa, emosi yang menjadi representasi keindahan bentuk dari rasa, emosi atau intuitif seorang pelukis. Di mana keindahan rasa, emosi atau intuitif itu yang dimunculkan oleh seorang seniman. Keempat keindahan bentuk spiritualitas seorang pelukis, membuat karya seni lukisnya sebagai representasi dari keindahan spiritualitas seorang pelukis.

Dengan demikian keindahan sebuah karya seni memberikan makna dari karya seni lukis yang dibuatnya. Bahwa tema dan bentuk sebagai mediasi nilai keindahan yang ingin disampaikan oleh seorang pelukis di dalam membuat karya lukisannnya.

Menurut Plato keindahan absolut merupakan sumber dari segala penyempurnaan dari pada segala keindahan. Menurut Plato "cinta" adalah merupakkan keindahan yang ideal, yang akan mengantarkan kita pada keindahan absolut.

Keindahan bentuk sebagai bentuk, keindahan gagasan, keindahan rasa, emosi atau intuitif dan keindahan spiritual. Menghasilkan karya seni lukis yang berbeda satu sama lain. Sebagai representasi dari apa yang menjadi pengalaman, berdasarkan apa yang dialami oleh seorang pelukis.

Pemikiran estetika modern menggunakan pendekatan induktif dalam melihat persoalan keindahan. Artinya suatu keindahan adalah hasil generalisasi atas data atau fakta-fakta empirik yang diperoleh melalui suatu proses pengamatan seperti layaknya yang terjadi dalam tradisi ilmu pengetahuan ilmiah. 
Dalam paham ini keindahan didekati dan dijelaskan secara ilmiah dengan menggunakan ilmu-ilmu pengetahuan ilmiah seperti ilmu Psikologi, Sosiologi, Antropologi, Sejarah dan bahkan ada yang mendekatkan dan penjelasan ilmu Matematika. Implikasi menggunakan pendekatan atau cara pandang keilmuan ini, maka konsep keindahan akan menampakkan standar, sifat, nilai atau penjelasan yang berbeda sesuai dengan kebenaran disiplin masing-masing ilmu tersebut.

Estetika modernisme mengembangkan narasi-narasi besar dalam bentuk isme-isme yang berkembang antara lain rasionalisme, kapitalisme, individualisme, kubisme, realisme, abstrakisme, ekspresionisme, dan sebagainya yang berdampak terjadinya dehumanisasi yaitu kehidupan dan kreativitas yang terkotak-kotak, diplot-plot dan kaku seakan kebenaran itu bersifat tunggal hanya yang berada di wilayah narasi-narasi besar ini. Ideologi modernisme bersemangat melakukan kooptasi yaitu semacam upaya untuk mengarahkan segala sesuatu menurut standar atau ukuran yang sudah ada atau baku (universalisme).

Menurut padang estetika Resepsi adalah yang berhubungan dengan nilai sebagai fakta-fakta sosial. Norma estetika adalah regulator terhadap fungsi estetis itu sendiri, aturan yang bergerak secara terus menerus dan selalu diperbaharui

Pengalaman Estetis adalah proses, reproduksi secara terus-menerus melalui mediasi-mediasi institusi, sesuai dengan jaringan yang tersedia dalam masing-masing bentuk karya seni.

Dengan demikian ada karya lukisan naturalisme sebagai keindahan bentuk, ada karya lukisan konseptual art sebagai keindahan dari sebuah gagasaan, ada karya lukisan ekspresionisme sebagai dari keindahan rasa, emosi atau intuitif, ada karya lukisan menggambarkan nilai keagamaan, lukisan kaligrafi 
sebagai dari sebuah keindahan spiritualitas. Sebagai sebuah penekan dari makna seni lukis yang dibuat oleh seorang pelukis.

Namun kualitas keindahan tidak dapat ditentukan secara faktual. Artinya, untuk mengetahui keberadaannya diperlukan pemahaman, sudut pandang, paradigma, bahkan logika yang berkaitan dan dengan hakekat obyek dengan demikian hakikat nilai-nilai estetis itu sendiri. Estetika adalah bagaimana karya seni bisa dipahami secara baik oleh setiap orang, agar bisa menempat estetis seni pada porsinya.

Dalam memberikan pemaknaan, seorang penafsir terikat oleh aspek tematik, pertama, tidak ada titik nol yang absolut sebagai awal menafsirkan makna, kedua, tidak ada pandangan yang bersifat total untuk memahami suatu obyek dalam sekejap, ketiga, tidak ada penafsiran secara total sehingga tidak ada pula situasi yang mutlak membatasi, keempat peluang memadukan antara fenomena, karena fenomena yang diamati manusia pada hakikatnya tidak bersifa tertutup.

Membuat karya seni lukis menjadi makna dari sebuah ekspresi di dalam berkarya. Makna bisa menjadi sebuah hubungan bentuk dengan konsep atau gagasan kreativitas seorang pelukis ketika sedang berkarya. Pengertian makna yang dikutik oleh Nasbahry dan Minarsih dari James T Saw meliputi tiga makna seni, sebagai berikut,

1) Makna seni sehubungan dengan konsep-konsep seniman atau pelukis, yaitu sejauh mana konsep-konsepnya terlihat pada karyanya.

2) Makna seni sehubungan dengan tanggapan estetika dan kritik pengamat. Makna ini bisa tidak sama dengan maksud/konsep seniman atau pelukisnya.

3) Makna seni sesuai dengan kesepakatan sosial budaya terhadap karya seni. Jenis terakhir ini termasuk ilmu ikonografi. 
Misalnya, ilmu yang mempelajari bahasa gambar (ikon) atau system tanda pada gambar, atau sesuai dengan lambanglambang yang dimiliki oleh sebuah kultur pada waktu tertentu.

Menurut pandangan estetika Resepsi, karya seni merupakan sebuah tanda, karena karya seni itu tidak terpisah dengan latar belakang sosial. Keindahan karya seni deotomatisasi dan defamiliarisasi, bahwa keindahan karya seni bukan semata-mata merupakan kompetensi seni. Tapi keindahan karya seni dalam kehidupan sehari-hari mempunyai fungsi keindahan sebagai bentuk sekunder.

Dalam teori estetik Resepsi Mukarovsky menjelaskan dan membedakan antara artefak dengan obyek estetis. Artefak merupakan perangkat material, huruf-huruf yang tercetak pada halaman kertas atau cat dalam kanvas, sedangkan obyek estetis merupakan representasi artefak yang terjadi dalam pemikiran pembaca atau pengamat dalam kesadaran kolektif.

Dalam menjelaskan sebuah pemaknaan dari karya seni lukis dengan tema alam benda, figur dan lingkungan realitas sosial budaya menjadi keindahan karya seni lukis yang merupakan representasi karya yang terjadi dalam gagasan seorang pelukis dalam membuat karyanya.

Menurut Bourriaud, seni relasional mencakup "serangkaian praktek artistik yang mengambil titik teoretis dan praktis keberangkatan seluruh hubungan manusia dan konteks sosial mereka, bukan ruang yang independen dan swasta." Karya seni Estetika Relasional menciptakan lingkungan sosial di mana orangorang datang bersama-sama untuk berpartisipasi dalam kegiatan bersama. "Peran karya seni tidak lagi untuk membentuk realitas imajiner dan utopis, tetapi untuk benar-benar menjadi cara hidup dan model aksi dalam nyata yang ada, skala apapun yang dipilih oleh seniman." 
Dalam seni relasional, penonton dipertimbangkan sebagai sebuah komunitas. Dari pada karya seni sebagai sebuah pertemuan antara penampil dan obyek, seni relasional menghasilkan pertemuan intersubjektif. Melalui pertemuan ini, makna kolektif diuraikan, bukan di ruang konsumsi individu.

\section{Strategi Berkarya Seni Lukis}

Strategi adalah pendekatan secara keseluruhan yang berkaitan dengan pelaksanaan gagasan, perencanaan, dan eksekusi sebuah aktivitas dalam kurun waktu tertentu. Agar bisa mencapai tujuan yang sebenarnya, tidak terkondisi pada situasi tertentu. Bahwa apa yang dilakukan merupakan kesadaran yang disudah diantisipasi dalam proses berkesenian.

Strategi membuat karya seni lukis sebagai langkah-langkah proses berkesenian yang dilakukan seorang pelukis di dalam berkarya. Dengan menetapkan cara pandangan di dalam berkarya seni lukis secara luas. Bahwa landasan berkesenian memberikan ruang kemungkinan di dalam berkarya seni.

Bahwa apa yang dilakukan di dalam berkarya seni lukis menghasilkan berbagai macam "Bentuk", sebagai landasan berkarya seni lukis dan berkarya seni di dalam perkembangan zamannya, yaitu;

1) Bentuk Gagasan yang muncul dalam upaya ingin membuat karya seni lukis sebagai landasan berkarya seni yang lebih luas dan bermakna dan memakna dari berbagai media, bentuk dan konstekstual dari realitas sosial budaya masyarakatnya.

2) Bentuk Kreativitas sebagai seorang pelukis dengan sendiri akan dapat dirasakan dan diformulasikan menjadi sebuah model berkarya selanjutnya. Tidak menutup kemungkinan akan dikembangkan lagi atau mengalami perkembangan selanjutnya, sejalan dengan perkembangan gagasan karya seni 
selanjutnya. Sebagai pencentus berkarya seni secara tumbuh kembang dan berkelanjutan. Memungkinkan seorang pelukis berkembang dengan keterbukaan di dalam gagasan dan media ungkapnya.

3) Bentuk Tahapan Implementasi dalam membuat karya seni lukis di dalam mengimplentasikan karya seni lukis menjadi bentuk tersendiri. Dengan membuat tahapan dalam bentuk bagan atau skema dalam membuat karya seni lukis. Dengan demikian tahapan itu juga menjadi model di dalam mengimplementasi di dalam proses berkarya seni lukis. Menjadi sebuah konsep tahapan implementasi berkarya seni bagi seorang seniman.

4) Bentuk Teknik seni lukis yang diketahui dan dipraktikan, sehingga mengalami proses implementsi dengan cara menjajaki teknik seni lukis yang dipergunakan untuk mendapatkan kesesuaian dengan gagasan atau bentuk yang lain dari tahapan bentuk yang dijelaskan.

Dengan begitu teknik seni lukis yang dipahami dan dikuasai, secara terstruktur akan ada pengurangan, penambahan atau menjadi bentuk kombinasi dari beberapa teknik seni lukis. Bisa juga akan menghasilkan teknik baru, yang berdasar dari teknik yang dikuasai.

Dikarenakan dari perkembangan gagasan, kreativitas, model tahapan dan teknik itu sendiri. Teknik seni lukis sebagai dasar dari pengetahuan seni lukis masa lalu mendasari pada perkembangan teknik seni lukis pada zaman dan yang akan datang.

Sebagai sesuatu perkembangan yang memang menjadi sebuah realtias sosial budaya dari perkembangan manusia pada umumnnya, perkembangan ilmu pengetahuan, teknologi dan informasi. Sebagai konsep teknik di dalam membuat karya seni lukis sebagai landasan berkarya. 
Strategi berkarya seni lukis ini mempunyai tahapan sebagai landasan berkesenian bagi seorang pelukis. Dengan demikian berkarya bukan pada membuat karya seni lukis. Tetapi gagasan, kreativitas, tahapan implementasi, kemampuan konsep teknik, menjadi kesadaran bahwa berkarya itu merupakan pengetahuan seni, sehingga bisa mengevaluasi diri sebagai bentuk formatif, di dalam berkarya bukan saja karya lukis yang dipamerkan tanpa peranan mahasiswa sebagai seorang pelukis.

Untuk membangun kesadaran dan kemampuan kuratorial di dalam membuat pameran. Berpameran sama artinya dengan membuat karya seni lukis dalam sebuah gagasan berkembang antara karya lukisan dengan ruang, pencahayaan, warna dinding dan bentuk pameran yang ingin digagasannya.

Pengetahuan itu semua tidak lepas pada sebuah kreativitas seorang pelukis dalam melihat gagasan sebagai sebuah penjelajahan yang dibentuk dalam sebuah kemampuan berkarya. Kemudian kemampuan gagasan, teknik dan kesadaran akan pengetahuan seni yang digeluti mampu diformulasikan menjadi konsep berkesenian.

Untuk melihat berkarya seni lukis merupakan landasan berkesenian dan kemampuan melihat karya lukisan sebagai sebuah karya seni. Sebagai sebuah interaktif dan transformasi gagasan, estetika pada realitas sosial budaya masyarakat. Kontekstualitas seni dalam budaya manusia yang melihat pertumbuhan dan perkembangan karya seni.

Sebuah karya seni lukis tidak dibuat dengan apa yang dilihat dan dibentuknya. Tapi dalam karya lukisan itu akan tercermin pada kemampuan seorang pelukis dan penampilannnya, seperti apa yang dijelaskan oleh Guilford sendiri menemukan yang menjadi faktor seseorang mempunyai kemampuan berpikir kreatif, yaitu : 
1. Kelancaran berpikir (fluency of thinking), yaitu kemampuan untuk menghasilkan banyak ide.

2. Keluwesan (flexibility), yaitu kemampuan untuk memproduksi sejumlah ide, dapat melihat suatu masalah dari sudut pandang berbeda-beda, mencari alternatif atau arah yang berbeda-beda, dan mampu menggunakan bermacam-macam pendekatan atau cara pemikiran.

3. Elaborasi (elaboration), yaitu sebagai kemampuan dalam mengembangkan gagasan berkarya dan menambah atau memperinci detil-detil dari suatu obyek, gagasan atau situasi sehingga menjadi lebih menarik.

4. Keaslian (originality), yaitu sebagai kemampuan untuk mencetuskan gagasan dalam berkarya yang unik (unusual) atau kemampuan untuk mencetuskan gagasan asli.

Penjelasan itu merupakan sebuah gambaran dari sikap dan penampilan seorang pelukis yang mempunyai sikap dan cara berpikir kreatif. Seorang pelukis dalam perkembangannya tidak hanya pada kemampuan teknik, tapi mampu menempatkan diri dan keberadaan dalam pemikiran.

Dengan demikian seorang pelukis dituntut juga kemampuan untuk memformulasikan keseniannya di dalam berkarya seni lukis. Untuk itu perlu ada pemahaman tentang seni lukis dalam prosesnya, sebagai bagian dari perkembangan dirinya sebagai seorang pelukis.

Hal itu digambarkan dalam melihat tahapannya sebelum berkarya sebagai bentuk pergolakan dirinya. Untuk menghasilkan karya seni lukis yang dilihat sebagaimana mestinya sebuah karya seni lukis. Tapi juga mampu menghasilkan spirit dari seorang pelukis yang mengalami proses di dalam dirinya.

Seorang pelukis dalam membuat karya seni lukis adalah sebuah proses kreatif yang memerlukan tahapan dilalui dengan 
Karya lukisan Monalisa sebagai karya yang lebih menekan pada kemampuan di dalam membuat karya lukisan. Bahwa apa yang dilukisan lebih melihat obyek sebagai lukisan untuk memperlihatkan keindahan seni dalam menangkap figur wanita.

Meskipun dalam perkembangan sejarah lukisan ini tidak lepas dari kajian seni, budaya dan aspek psikologi. Dengan sendiri memperkaya lukisan Monalisa menjadi sebuah pengetahuan yang berkembang melalui karya seni lukis.

Dengan begitu akan memberikan inspirasi sebuah kesempurnaan dari seorang wanita. Karya lukisan Monalisa dilihat sebuah karya lukisan non contoh dari sebuah karya lukisan yang meng-gambarkan realitas sosial budaya dari sebuah masyarakat. 


\section{Glosarium}

Sosial : Sekelompok individu yang disatukan oleh seperangkat perbedaan dan seperangkat sistem hubungan normatif, yang tindakan memicu respons yang khas pada yang lainnya.

Realitas: Mengacu kepada penggambaran manusia dan benda sebagaiman ia melihat dengan mata atau dipikirkan, tanpa idealisasi, tanpa distorsi.

Estetika Resepsi : yang berhubungan dengan nilai sebagai faktafakta sosial. Norma estetika adalah regulator terhadap fungsi estetis itu sendiri, aturan yang bergerak secara terus menerus dan selalu diperbaharui

Makna : bisa menjadi sebuah hubungan bentuk dengan konsep atau gagasan kreativitas seorang pelukis ketika sedang berkarya.

Strategi : Pendekatan secara keseluruhan yang berkaitan dengan pelaksanaan gagasan, perencanaan, dan eksekusi sebuah aktivitas dalam kurun waktu tertentu.

Seni Relasional : mencakup "serangkaian praktek artistik yang mengambil titik teoretis dan praktis keberangkatan seluruh hubungan manusia dan konteks sosial mereka, bukan ruang yang independen dan swasta. 


\section{DAFTAR PUSTAKA}

1. Philip, Berrill. 2008. Everyone's Guide to Oil Painting, Berrill Philip Internasional Ltd. Terjemahan. Jakarta: Penerbit Akademia Jakarta.

2. Philip, Berrill. 2008. Everyone's Guide to Water Colour Painting. Berrill Philip Internasional Ltd. Terjemahan. Jakarta: Penerbit Akademia Jakarta.

3. Philip, Berrill. 2008. Everyone's Guide to Pastel Painting, Berrill Philip Internasional Ltd. Terjemahan. Jakarta: Penerbit Akademia Jakarta.

4. Hujatnikajennong, Agung. 2015. Kurasi dan Kuasa, Tangerang: Penerbit Marji Kiri.

5. Nashori, Fuad. 2002. Mengembangkan Kreativitas Dalam Perpektif Psikologi Islam. Yogyakarta: Penerbit Menara Kudus.

6. Sutrisno, Mudji dan Hendar Putranto. 2005. Teori-Teori Kebudayaan, Yogyakarta: Penerbit Kanisius.

7. Schari, Agus. 2007. Budaya Visual Indonesia, Jakarta: Penerbit Erlangga. 
Seni Lukis, Kansep dan Metade

192 
teknik sapuan dalam melukis mampu mengolah media dan sapuan berkarakter di dalam melukis menjadi lebih penting.

Sapuan dalam melukis menjadi sebuah spirit, karena dengan mudah akan memberikan kreativitas berkarya sehingga mampu mengembangkan dan menemukan bahasa visual yang menarik dan inspiratif bagi masyarakat dalam melihat permasalahan realitas sosial budaya.

Menjelaskan bahwa sapuan dalam lukisan itu menjadi gagasan yang bisa mengembangkan teknik formal menjadi lebih ekspresi dari sebuah karya lukisannya, dan akan menjadi lebih kreativitas.

Untuk menemukan pemahaman dan pencerahan di dalam berkarya seni lukis. Ekspresikan dengan berbagai macam sapuan dalam melukis, selain mengungkapkan pengalaman, tapi juga menjelajahkan pengalaman sebagai sebuah kesadaran tentang realitas sosial budaya.

\section{Teknik Seni lukis}

Teknik seni lukis kita akan merujuk pada pengertian techonological art atau disebut juga Tech atau Tek art, Corporate art, merupakan seni yang diciptakan dengan bantuan teknologi.

Tapi sekarang, kata "teknologi" menandakan konsep yang lebih luas dari pada hanya kemampuan tentang keterampilan khusus ini menunjukkan pengetahuan teknik, proses dan metode dari pengunaan pengetahuan yang digabung dengan sumber daya material secara besar-besaran, modal dan pekerja tersebar oleh industri modern.

Pengertian ini dilihat dalam arti formal, teknik dalam seni lukis lebih pada kemampuan menguasai teknik melukis dengan baik. Teknik yang berkaitan dengan mempergunakan media dan mengembangkan pengetahuan teknik dengan media yang lain. 
Sesuai dengan kemampuan dan perkembangan ide dan gagasan dari seorang pelukis.

Pengertian teknik dalam arti luas, yang bersifat konseptual, lebih pada pemikiran dalam menganalisis teknik satu dengan yang lain. Bersifat teknologi trapan yang berkaitan kontektualitas permasalahan dalam berkarya. Dengan demikian sebuah karya seni lukis bergerak dan berkembangan sesuai dengan perkembangan dari kehidupan manusia dalam melihat realitas sosial budaya.

Teknik berkarya seni untuk memenuhi kebutuhan gagasan berkarya, sehingga memerlukan teknik yang berbeda, lain atau teknik baru sesuai dengan kebutuhan berkarya seni. Berdasarkan pada pengetahuan seni, yang membuat karya lukisan itu menjadi sebuah karya seni.

Namun secara umum dalam melukis dibagi dalam dua teknik yang berkaitan dengan material atau bahan, sebagai media untuk melukis, sebagai berikut:

1). Teknik basah, sebuah teknik dalam menggambar atau melukis yang menggunakan media yang bersifat basah atau memakai media air dan minyak cair, seperti cat air, cat minyak, tempera, tinta, rapido gram dan lain-lain. Jenis karya yang dihasilkan seperti sketsa tinta cina atau di Jepang disebut sumi.

2). Teknik kering kebalikan dari teknik basah, menggambar atau melukis dengan bahan kering seperti charcoal (arang gambar), pensil, orang dan lain-lain. Teknik kering telah berusia tua yaitu sejam zaman Paleolitikum sekitar tahun 15.000 SM, dengan menggoreskan warna alam ke dinding gua. Jenis gambar yang dihasilkan dengan teknik kering; stippling dan scartcboard.

Seni lukis membeberkan pandangannya sebagai berikut : Dengan mengikuti model yang dibuat oleh Aristoteles dan kemudian Alberti, Leonardo melihat kegiatan seni itu mencakup 
tahapan observasi alam dan rincian-rinciannya secara keilmuan, menuju tahapan momentum inspirasi illahi.

Yang dimaksud dengan tahapan kedua agaknya adalah bahwa inspirasi illahi yang pada momentum atau saat tertentu diperoleh itu akan dapat membantu menampilkan kembali alam yang telah diobservasi secara cermat.

Seperti halnya dengan para pengikut Platoisme, maka Leonardo menggambarkan jiwa itu dalam bentuk segi tiga, dan bentuk inilah yang biasanya digunakan di dalam menyusun komposisi lukisnnya. Contohnya dapat dilihat pada lukisannya berjudul "Madona of the Rock", dan Madona and St, Anne; kedua-duanya disimpan di meseum Lauvre, Paris.

Namun baginya keindahan suatu lukisan itu lebih ditentukan oleh unsur kiaroskuro, atau tepatnya oleh peralihan antara bagian yang gelap dan terang. Seorang pelukis harus dapat melihat dengan jeli bagaimana bayang-bayang itu, seperti halnya dengan asap yang secara gradual diserap oleh udara.

Leonardo terkenal sebagai orang pertama yang menggunakan teknik sfumato, suatu cara memperlunak garis kontur dengan jalan menyapu kontur tersebut dengan warna transparan dan kabur(a haze of glazed color).

Dewey percaya bahwa ada objektivitas dalam evaluasi seni didasarkan pada beberapa faktor. Pertama, karya seni itu adalah bagian dari dunia objektif dan dikondisikan oleh bahan dan energi dari dunia. Kedua, untuk sebuah objek menjadi isi dari pengalaman estetis itu harus memenuhi kondisi obyektif yang termasuk ke dunia. Inilah sebabnya mengapa seniman menunjukkan minat di kehidupan dunia, dan bahannya.

Pertama dan paling penting dari kondisi obyektif adalah irama. Irama sudah ada di alam. Irama fajar dan matahari terbenam, hujan dan bersinar, musim, pergerakan bulan dan bintang- 
bintang, reproduksi dan kematian, bangun dan tidur, detak jantung dan napas, dan irama yang terlibat dalam bekerja dengan bahan, semua dilihat oleh orang awal sebagai memiliki makna misterius yang berkaitan dengan kelangsungan hidup mereka.

Bahkan lebih signifikan adalah irama yang terlibat dengan mempersiapkan perang dan untuk penanaman. Peristiwa dramatis juga menyebabkan orang untuk memaksakan atau memperkenalkan irama yang sebelumnya tidak ada.

Mereproduksi irama alam yang dihasilkan rasa drama dalam kehidupan. Esensi dari hewan yang dibawa ke kehidupan di irama tari, patung dan lukisan. Menggabungkan seni formatif dan irama suara dan tari menyebabkan seni rupa.

Manusia datang untuk menggunakan irama alam untuk merayakan hubungannya dengan alam dan untuk memperingati pengalaman yang paling intens. Pada awalnya ada perbedaan dibuat antara seni dan ilmu pengetahuan dalam reproduksi perubahan ini. Misalnya, cerita Yunani pertama tentang asal-usul alam memiliki bentuk estetika, dan ide hukum alam berasal dari ide harmoni.

\section{Konsep Sapuan Halus, Kasar dan Ekspresif}

Konsep sapuan dalam karya lukisan bukan hanya sekedar sapuan di atas kanvas, tapi merupakan bagian dari ungkapan dari gagasan dan kreativitas, sebagai makna yang diinterpretasi oleh seorang pelukis. Untuk bisa diformulasikan atau bisa dirasakan sebagai pengalaman keindahan dalam realitas sosial budaya masyarakat. Memperlihatkan dalam setiap sapuan dalam karya seni lukis memang menjadi representasi seorang pelukis.

Brushstroke dalam bahasa Inggris mempunyai pengertian dalam melukis yang berarti memiliki sifat atau karakter goresan yang memiliki ukuran atau kualitas tertentu, berhubungan dengan 
kekuatan emosi, ketajaman warna dan kadang-kadang goresan yang emosional. Memberikan kekuatan dan menembus gagasan, rasa, imajinasi dan pembaharuan dalam arti luas sebagai penemuan, arti terbatas pada penemuan seorang pelukis pada proses berkarya seni lukis sebelumnnya.

Sapuan bagian dari elemen seni rupa yang membangunkan rasa dan emosi dalam konsep seni lukis yang dibuatnya. Sapuannya mengantarkan pada pemahaman bentuk dan gaya seni lukis yang di identifikasi, misalnya sebagai seni lukis abstrak, ekspresionisme, realis dan sebagainya.

Gagasan dan kreativitas direpresentasikan pada sebuah sapuan yang bergerak di atas kanvas atau bidang datar yang lain. Menunjukkan pada intensitas dalam mengolah warna, bentuk, komposisi dan tekstur dalam sebuah lukisan. Sapuan dalam lukisan itu akan menghasilkan sapuan halus, kasar dan ekspresif.

Sebuah karya lukisan yang paling menonjol adalah sapuan kuas yang dipergunakan. Melukis dalam membentuk obyek atau mengekspresikan sapuan diatas kanvas bisa dilihat dengan berbagai macam sapuan, yaitu sapuan halus, kasar dan ekspresi. Kesemuanya bisa memberikan interpretasi yang berbeda dalam sebuah karya lukisan. Masing-masing mempunyai maksud dan tujuan yang berbeda.

\section{Impulsif Sapuan Halus}

Sapuan kuas yang halus mempunyai tujuan ingin mencapai sebuah obyek lukisan yang indah dan menyerupai keindahan, seperti karya lukisan naturalisme.

Hal ini yang bisa kita dalam karya lukisan Anthony Van Dyck (1599 - 1641) adalah pengikut Rubens. la merupakan seorang pelukis potret yang sangat menonjol. Karena karya yang 
halus dan anggun. Ada sesuatu ingin dicapai dalam membuat sapuan halus dilukisan yang dibuatnnya.

Sapuan halus memang bisa dipergunakan untuk terang gelap dalam sebuah lukisan. Membuat kedalam dalam perspektif dalam karya lukisan. Membuat dramatis dalam sebuah karya lukisan, seperti karya lukisan kaum romantisme.

Mengedepankan perasanan dan spirit hidup secara implusif. Turner yang lebih impulsif, "melupakan" gambar untuk lebih menitikberatkan pada atmosfer cahaya, efek kabut, bayangan badai, serta terbit dan terbenamnya matahari.

Sapuan halus dalam seni lukis yang dibuat mempergunakan teknik seni lukis Chiarascuro dengan menekankan pada cahaya dalam obyek lukisan, sehingga memberikan kesan bayang obyek dari lukisan. Kesan bayang yang dimunculkan oleh sapuan kuas yang halus memberikan dimensi ruang.

Dengan demikian sapuan halus dari karya lukisan, biasanya lebih membutuhkan pemahaman bentuk terhadap aspek terang gelap sebagai bentuk bayangan. Kehalusan bentuk, baik itu alam benda, figur dalam komposisi dengan pantulan cahaya sebagai gagasan dramatis dan lebih menekan pada kekuatan obyek lukisan yang dibuatnya.

Begitu juga sapuan halus dalam lukisan, juga dipergunakan dalam teknik melukis Tenebrisme, sebagai bentuk sapuan halus yang mengarahkan pada suasana yang terang gelap dengan warna yang bergradasi. Membuat karya lukisan yang dibuat obyek selalu terlihat dengan pencahayaan yang jelas.

Teknik melukis Tenebrisme mempunyai kesamaan dengan Chiarascuro dalam pencahayaan. Memberikan kekuatan dalam karya lukisan yang dibuatnya. Beda Tenebrisme sumber cahaya dapat dilukisankan secara jelas. Sedangkan Chiarascuro pencahayaan dalam lukisannya tidak dapat terlihat dengan jelas. 
kecil dengan ujung. Juga dapat digunakan untuk menutupi banyak ruang, mirip dengan kuas yang menyapu datar dalam sebuah kanvas sebagai medan penjelajahan yang menarik.

Di sisi sangat positif, ini adalah sapuan kuas ini untuk melakukan shading(bayangan) dalam lukisan sehingga memberikan ketegasan pada sebuah obyek utama dari karya seni lukis tersebut.

Dan itu sangat didambakan oleh seniman yang suka melukis mawar dan bunga karena mereka bisa masuk ke semua sudut dan celah kecil. Jadi, jika seorang pelukis dalam melukis bunga mawar yang realistis, mempertimbangkan untuk mencoba kuas untuk melukis ini. Tapi untuk sapuan panjang atau strokework bukan pilihan yang tepat dan terbaik untuk menggunakan flat.

\section{c. Kuas Blender}

Blender ialah kuas yang bentuknya tersusun dari bulu yang rata, dipergunakan melengkapi bentuk dan volume dalam karya seni lukis. Secara khusus kuas blender ini tidak ada, lebih bersifat paduan dengan kuas lain. Sebagai proses melukis di dalam membentuk obyek melalui warna dan memadukan warna lain, sehingga menjadi paduan warna atau menghasilkan warna lukisan yang diinginkan.

Kuas blender mempunyai beberapa ukuran, sesaui dengan kebutuhan di dalam membuat lukisan yang tidak khusus. Kuas blender lebih serba guna dalam membuat lukisan, sehingga dipergunakan dengan berbagai kuas yang sama dengan waran yang berbeda. Ketika mempergunakan cat minyak, dan juga cat akrilik, meskipun lebih mudah untuk membersihkan dibanding dengan mempergunakan cat minyak. 


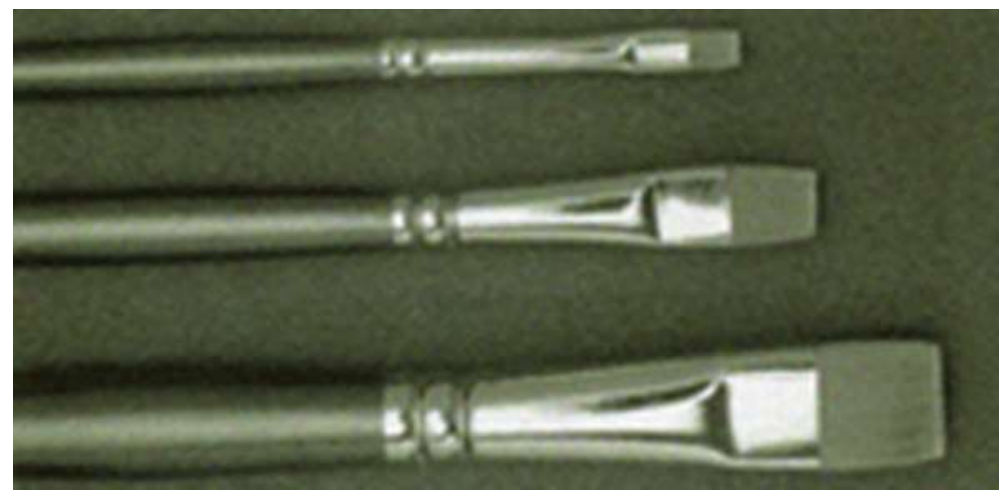

Gambar 53. Kuas Blender

\section{d. Kuas Round}

Jenis kuas cat mempunyai berbagai macam ukuran, yang terkecil menjadi 20/0 hingga sampai hal yang sepanjang dengan ukuran 10. Sebagian besar mereka digunakan untuk strokework dan cat air. Yang satu ini sangat berharga sebagai alat pengajaran untuk menyempurnakan kontrol kuas dalam melukis. Untuk menyempur-nakan sebuah karya lukisan dalam sebuah proses.

Melukis dengan mempergunakan kuas ini baik untuk membuat sketsa. Menguraikan bentuk yang detail, kerja secara terperinci mampu memperjelas obyek yang diinginkan. Sapuan kuas ini mudah dan terkontrol, mengisi di daerah kecil.

Menciptakan tipis untuk garis tebal - tipis di ujung, menjadi lebih luas lagi yang ditekan dalam lukisan ini digunakan dengan cat menipis daripada cat tebal, memberikan aksentuasi dalam lukisan yang digarapnya. Menunjuk kuas lukisan mampu berputaran sesuai dengan keinginan kita dalam mencapai ekspresikan yang didapat. 


\section{Glosarium}

Tema : dalam melukis untuk mengarahkan dan fokus pada permasalahannya dengan pada berbasis realitas sosial budaya sebagai dari representasi makna dari tema lukisan yang dibuatnya. Brushstroke : Pengertian dalam melukis yang berarti memiliki sifat atau karakter goresan yang memiliki ukuran atau kualitas tertentu, berhubungan dengan kekuatan emosi, ketajaman warna dan kadang-kadang goresan yang emosional.

Blender : Kuas yang bentuknya tersusun dari bulu yang rata, dipergunakan melengkapi bentuk dan volume dalam karya seni lukis.

Fan : Kuas ini lebih memberikan aksentuasi pada sebuah gambar dalam datar, sehingga memudahkan untuk mengungkapkan keindahan dalam sebuah karya lukisan

Flat : Jenis kuas cat yang akan seorang pelukis digunakan untuk membuat lukisan yang sesuai dengan apa yang ingin diungkapkan. Di mana seorang yang ingin melukis akan menggunakannya kuas flat ini. Untuk membuat pelapisan dasar di atas kanvas, mengambang sapuan kuas, strokework.

Filbert : Kuas datar tapi memiliki ujung bulat dipahat bukan yang lurus. Semacam lidah kucing. Ketika seorang pelukis melihat jenis kuas ini dari tepi dipahat, bulu-bulu harus membentuk keunggulan bahkan oval. Sebagai sapuan dalam menyempurnakan karya lukisan secara keseluruhan bentuk atau obyek dari karya lukisan.

Kuas : Media yang menyalurkan kekuatan ekspresi seorang pelukis untuk menjelajah warna di kanvas. Untuk menemukan sesuatu yang baru dalam hidupnya. Bagi seorang pelukis kuas cat menjadi alat tercinta apa bila semakin pelukis menggunakannya secara baik dan menemukan apa yang menjadi keinginannya. 
liners : Kuas panjang dan ketebalan. Ini berarti bahwa memilih batasan yang tepat dapat menantang

Pisau Palet : Alat tumpul yang digunakan oleh seorang seniman membuat karya seni lukis. Memiliki, pisau lurus panjang dan terutama digunakan untuk cat pencampuran dan gesekan palet bersih ketika sesi lukisan selesai.

Teknik basah : Sebuah teknik dalam menggambar atau melukis yang menggunakan media yang bersifat basah atau memakai media air dan minyak cair, seperti cat air, cat minyak, tempera, tinta, rapido gram dan lain-lain. Jenis karya yang dihasilkan seperti sketsa tinta cina atau di Jepang disebut sumi.

Round : Jenis kuas cat mempunyai berbagai macam ukuran, yang terkecil menjadi 20/0 hingga sampai hal yang sepanjang dengan ukuran 10. Sebagian besar mereka digunakan untuk strokework dan cat air. Yang satu ini sangat berharga sebagai alat pengajaran untuk menyempurnakan kontrol kuas dalam melukis.

Sapuan halus : Mempunyai tujuan ingin mencapai sebuah obyek lukisan yang indah dan menyerupai keindahan

Sapuan ekspresi : Dalam seni lukis bisa dilihat dalam teknik seni lukis Impasto, menggunakan cat yang menjadi medium yang utama. Dengan memperguakan cat yang berlapis dengan mempergunakan pisau palet atau kuas, juga plotan dari tube cat, seperti apa yang lakuan Affandi.

Sapuan kasar : Memberikan intensitas dalam karya lukisannya untuk mencapai tujuan permasalahan yang dirasakan. Membuat karya lukisan dengan sendiri memberikan tanda yang bisa dirasakan oleh setiap orang

Teknik kering : Kebalikan dari teknik basah, menggambar atau melukis dengan bahan kering seperti charcoal (arang gambar), pensil, orang dan lain-lain. 
Abstrak Ekspresionis : Dieksplorasi cara-cara baru untuk menciptakan seni, menyegarkan dan menciptakan kembali media. Mereka mengubah sifat lukisan dengan besar, mereka abstrak kanvas, garis energik dan gestural, dan proses artistik baru. 


\section{DAFTAR PUSTAKA}

1. Philip, Berrill. 2008. Everyone's Guide to Oil Painting, Berrill Philip Internasional Ltd. Terjemahan. Jakarta: Penerbit Akademia Jakarta.

2. Philip, Berrill. 2008. Everyone's Guide to Water Colour Painting. Berrill Philip Internasional Ltd. Terjemahan. Jakarta: Penerbit Akademia Jakarta.

3. Philip, Berrill. 2008. Everyone's Guide to Pastel Painting, Berrill Philip Internasional Ltd. Terjemahan. Jakarta: Penerbit Akademia Jakarta.

4. Lian, D. 2007. Ensikopedia Pengetahuan, Solo: Penerbit Tiga Serangkai.

5. Sugiharto, Babang. 2015. Untuk Apa Seni. Bandung: Penerbit Matahari.

6. Data dari Internet http://en.wikipedia.org/wiki/Category:Painting_techniques

http://theportraitplace.co.uk/arttechneg.php www.creativespotlite.com 
me-mungkinkan studi dan analisis lebih jauh, melalui studi dan analisis.

Aliran merupakan paham atau isme yang lebih menyangkut pandangan atau prinsip yang lebih dalam sifatnya dari suatu karya seni rupa dan aliran tidak hanya ditentukan oleh bentuk fisik (visual) karya seni. Aliran lebih terkait pada paham, haluan, pendapat yang bersifat politis-ideologi, termasuk mempersoalkan pandangan hidup

Gaya atau corak yang memungkinkan studi dan analisis lebih jauh, melalui berbagai pendekataan:

1) Waktu, prasejarah, seni rupa Indonesia sebelum dan sesudah kemerdekaan, dan lain-lain

2) tempat atau daerah, wayang gaya Solo dan Yogya) dan lain-lain

3) Wujud, mempresentasional, abstrak, simbolik, teknik, seni lukis cat air, seni lukis cat minyak dan lain-lain

4) Subjectmatter, pemandangan, kehidupan, sosial, potret, alam benda, flora-fauna.

Feldman menawarkan cara pandang lain. la berusaha membahas gaya berdasarkan tendensi-tendensi prinsip yang tampak pada karya seni rupa yang sedang berkembang, ditinjuan dari perkembangan pengetahuan tentang proses interaksi antara sikap manusia, personalitas dan kreasi artistiknya, yang di dalamnya termasuk berbagai variasi gaya dalam seni modern. Feldman mengklasifikasikan gaya seni rupa ke dalam empat katagori:

1) Gaya Akurasi Obyektif

2) Gaya Formal

3) Gaya Emosi

4) Gaya fantasi.

Setiap seniman dan pelukis di dalam berkarya seni lukis mempunyai gaya seni yang berbeda. Masih banyak lagi gaya yang 
kalau dibahasanya, sesuai dengan perkembangan dan zamannya. Namun dalam pembahasan gaya ini, dibatasi pada konteks realitas sosial budaya yang menjadi basis dari kehiduapan para pelukis di dalam masyarakatnya.

Gaya menjadi pandangan dan bentuk karya seni lukis dalam sebuah aliran seni. Untuk itu gaya lukis yang kita bahas hanya beberapa gaya, diantaranya adalah:

\section{a. Gaya Seni lukis Naturalisme}

Seni lukis Naturalisme adalah suatu bentuk karya seni rupa untuk melukiskan segala sesuatu sesuai dengan natural atau alam kenyataan, artinya disesuaikan dengan tangkapan mata kita.

Supaya lukisan yang dibuat benar-benar mirip atau mendekati dengan nyata, maka susunan, perbandingan, perspektif, tekstur, pewarnaan serta gelap terang dikerjakan seteliti mungkin, setepat-tepatnya. Seni rupa, naturalis adalah usaha menampilkan obyek realitas sosial budaya dengan pendekatan latar belakang alam.

Dengan tokoh seni lukisnya adalah William Bliss Baker, yang dianggap lukisan pemandangannya baik dianggap lukisan realis terbaik dari gerakan ini. Seni lukis naturalisme, representasi yang bertujuan untuk mereproduksi obyek sebagai keyakinan atas alam. Lebih menekan pada keindahan dengan memilih obyek yang indah-indah. 
imajinasi serta keperdulian terhadap masalah sosial budaya. Sebagai bentuk ekspresi seseorang sebagai dirinya dan orang yang berkaitan dengan kehidupan realitas sosial budaya, menjadi kesadaraan hidupnya.

Dengan demikian seni lukis mempunyai media dalam bentuk material dan jiwa seseorang yang direpresentasikan. Namun hal itu tidak cukup untuk bisa melihat karya seni lukis berada dalam realitas kehidupan sosial budaya masyarakat.

Kesadaranlah yang perlu dibangun dan ditumbuhkan bahwa melukis itu adalah sebuah proses mengekspresikan diri dalam menelusuri nilai realitas sosial budaya masyarakat yang menjadi kehidupannya.

Dengan menghasilkan karya yang inspiratif dan membangun dan menumbuhkan kesadaran dirinya dan orang lain dalam melihat kehidupan ini menjadi lebih indah dan bermakna. Sebagai bentuk memperkaya jiwa dirinya dan realitas sosial budaya masyarakatnya menjadi lebih baik. Dengan ada perubahan cara berpikir, berpengaruh pada kehidupan realitas sosial budaya masyarakatnya yang lebih baik dan kreatif.

\section{f. Gaya seni lukis Abstrak Ekspresionisme}

Pelukis Abstrak Ekspresionis dieksplorasi cara-cara baru untuk menciptakan seni, menyegarkan dan menciptakan kembali media. Mereka mengubah sifat lukisan dengan besar, mereka abstrak kanvas, garis energik dan gestural, dan proses artistik baru. Banyak seniman bereksperimen dengan bahan-bahan nontradisional, seperti cat komersial dan kuas house painter ini.

Seorang pelukis, seniman juga mengembangkan teknikteknik baru untuk menerapkan cat, seperti memindahkan kanvas dari kuda-kuda ke lantai dan bekerja pada teregang dan bentangan kanvas. Dengan cara yang tidak konvensional lukisan, Abstrak 
Ekspresionis mencari bentuk-bentuk baru ekspresi diri dan kebebasan pribadi dalam pekerjaan mereka.

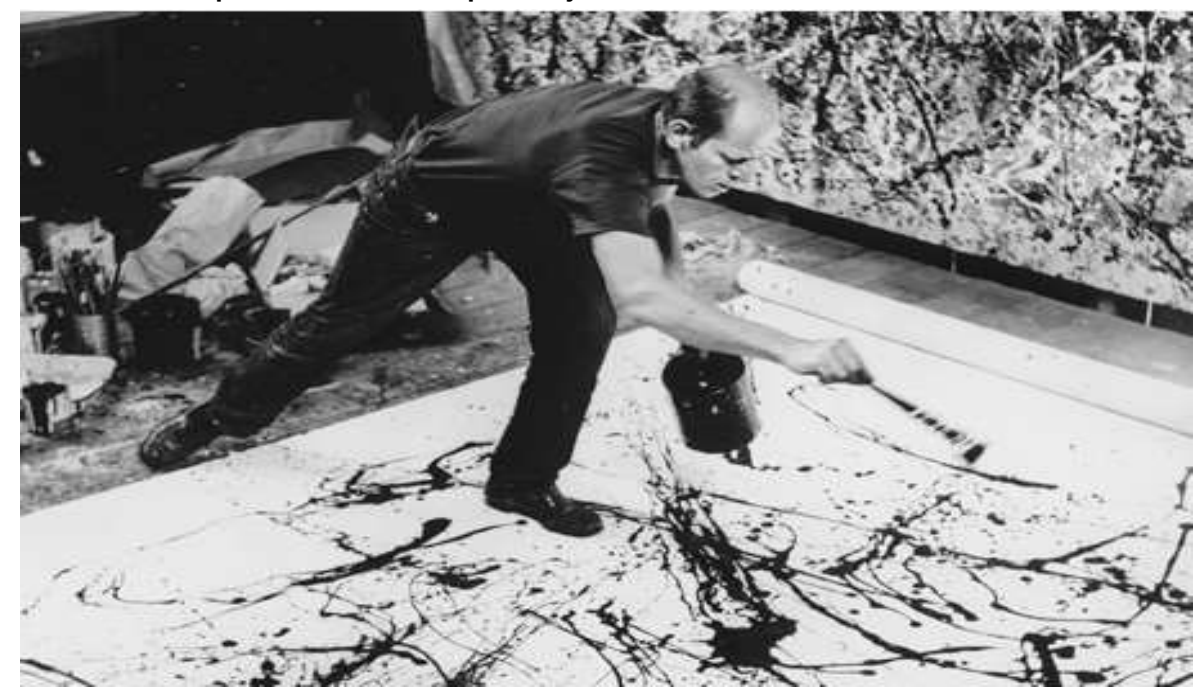

Gambar 69. Jackson Pollock sedang melukis, einweirsinfo.blogspot.co.id.

Jackson Pollock mungkin yang paling terkenal Abstrak ekspresionis, terkenal karena mural berukurannya lukisan, sebagai bentuk tindakan. Menempatkan kanvas di lantai, Pollock akan menetes, memercik, melemparkan, dan melumuri cat dari semua sisi. Tapi meskipun penampilan tampaknya spontan lukisannya, Pollock, seperti Ekspresionis Abstrak lainnya, mempertahankan keseim-bangan kekacauan dan kontrol

Jackson Pollock menyatakan: "Ketika saya dalam lukisan saya, saya tidak menyadari apa yang saya lakukan. Hanya setelah semacam 'berkenalan' periode itu saya melihat apa yang saya telah rasakan disekitarnya.

Saya tidak takut membuat perubahan, menghancurkan gambar, dll, karena lukisan itu memiliki kehidupan sendiri. Saya mencoba untuk membiarkannya datang melaluinya. Hanya ketika 
saya kehilangan kontak dengan lukisan yang hasilnya berantakan. Jika tidak ada harmoni murni, sebuah memberi mudah dan mengambil, dan lukisan itu keluar dengan baik.

\section{Contoh Karya}

Menjelaskan karya lukisan mahasiswa yang dipresentasikan dari tugas yang diberikan sesuai dengan temanya. Pembahasan pada masalah gagasan dan kreativitas yang dipahami dan dialam sebagai bagian dari proses implementasinya. Dalam karya lukisan yang berbasis realitas sosial budaya, untuk memperkuat pada identitas dan karakter di dalam berkarya.

Membuat pemahaman dalam berkarya menjadi lebih mengerti, sehingga mampu membuat karya lukisan menjadi lebih baik. Selain itu juga memahami proses yang berkaitan dengan elemen seni dan keindahan menjadi lebih menguasai.

Mampu mengeksplorasi di dalam berkarya. Untuk memfokuskan pada satu masalah yang dibahasnya. Membuat karya lukisan tidak terpaku pada bentuk saja, tapi menjadi sebuah pemahaman dan perenungan, sebagai refleksi dirinya terhadap realitas sosial budaya, di mana seorang pelukis berada. 


\section{Glosarium}

Gaya seni lukis : sebuah pengelompokan atau klasifikasi karyakarya seni. Suatu gaya seni rupa merupakan sebuah pengekelompokan atau klasifikasi karya-karya seni yang memungkinkan studi dan analisis lebih jauh, melalui studi dan analisis.

Ekspresionisme : Pergerakan budaya yang berasal dari Jerman pada awal abad ke 20 atas reaksi sebuah gerak sosial sebelumnya, yaitu positivisme dan beberapa art movement yang lain seperti naturalisme dan impresionisme.

Naturalisme : Suatu bentuk karya seni rupa untuk melukiskan segala sesuatu sesuai dengan natural atau alam kenyataan, artinya disesuaikan dengan tangkapan mata kita.

Romantisme: Seni lukis yang tidak berurusan sama sekali dengan suatu corak, sebab kepentingannya hanya dengan sikap batin yang melandasi sesuatu karya, dan bisa diproyeksikan pada segala macam gaya dan corak.

Realisme : Seni rupa menampilkan subyek dalam suatu karya sebagaimana tampil dalam kehidupan sehari-hari tanpa tambahan embel-embel atau interpretasi tertentu

Realisme Sosialis adalah gaya resmi disetujui seni yang mendominasi lukisan Soviet selama 50 tahun dari awal 1930-an. 


\section{DAFTAR PUSTAKA}

1. Kusrianto, Adi \& Made Arini. 2011. Histoy Of Art. Jakarta: Penerbit Elex Media Komputindo.

2. Philip, Berrill. 2008. Everyone's Guide to Oil Painting, Berrill Philip Internasional Ltd. Terjemahan. Jakarta: Penerbit Akademia Jakarta.

3. Philip, Berrill. 2008. Everyone's Guide to Water Colour Painting. Berrill Philip Internasional Ltd. Terjemahan. Jakarta: Penerbit Akademia Jakarta.

4. Philip, Berrill. 2008. Everyone's Guide to Pastel Painting, Berrill Philip Internasional Ltd. Terjemahan. Jakarta: Penerbit Akademia Jakarta.

5. Susanto Mike. 2011. Diksi Seni Rupa. Bali: Penerbitan Dicti Art Lab. Yogyakarta \& Jagad Art Space. 
Seni Lukis, Kansep dan Metade 
Tetapi juga harus dipahami dan disadari bahwa teknik itu bisa menjadi konsep teknik.

Dimana berkarya bukan mengacu pada teknik melukis yang sudah ada, tapi bagaimana gagasan melukis itu menemukan teknik yang memang tepat dan dibutuhkan di dalam gagasan melukis. Jadi teknik itu ditemukan, ada karena ada gagasan melukis yang memerlukan teknik berbeda dengan teknik yang sudah ada.

\section{Melukis Dengan Berbagai Media}

Melukis dibidang datar tidak terbatas pada media kertas, kanvas. Tetapi dalam perkembangan bukan pada bidang datar, tapi ditempat yang datar dengan berbagai macam bentuknya. Baik itu dua dimensi maupun tiga dimensi serta ruang kongkrit dalam ruang interior. Namun melukis seperti itu karena mengikuti dan mampu mengadaptasi dengan perkembangan tersebut, sebagai bentuk dari pengembangan konsep seni lukis sejalan dengan apa yang sedang berkembang di masyarakat..

Sedangkan dalam tingkat lanjut yang lebih jauh lagi, seni lukis di dalam mempergunakan media menjadi lebih luas. Sesuai dengan ide dan gagasan seorang pelukis. Bisa saja seorang pelukis bisa melukis dimedia batu, dinding, kayu, besi dan logam lainnya.

Dalam segi bentuk juga bisa memungkinkan untuk melukis dalam tiga dimensi, dan diruang dan waktu yang lebih luas lagi. Keluasan dalam mengembangkan gagasan melukis itulah yang mendasarkan pada basis sosial budaya masyarakat. Artinya seni lukis bisa diimplementasikan dalam media apapun juga sesuai dengan realitas sosial budaya masyarakatnya.

Menjelaskan media dalam berkarya seni lukis sebagai sebuah perkembangan dalam realitas sosial budaya masyarakat. 
Seorang pelukis dituntut untuk bisa menguasai media seni lukis dibeberapa materi yang dihatapi dan temukan.

Tanpa menghilangkan pemahaman dan kesadaran sebagai seorang pelukis yang mengacu pada kemampuan gagasan dan kreativitasnya serta kemampuan teknik dalam melukis. Berkarya dengan mempergunakan berbagai karya lukis sebagai pengembangan gagasan dan kreativitas dalam teknik seni lukis. Sebagai realitas sosial budaya yang ada di dalam kehidupan masyarakat yang berkembang.

\section{Pengembangan Teknik dan Gagasan Seni Lukis}

Seni lukis telah dipraktekkan selama tiga puluh ribu tahun. Sejarah panjang gaya lukisan memiliki banyak berubah, karena memiliki media di mana lukisan yang dilakukan zat, material, berkembangnya seorang pelukis menggunakan sebagai media seni lukis.

Dalam kasus terakhir mungkin akan lebih akurat. Hal ini memperluas dalam perkembangan teknik dalam seni lukis, sehingga tingkat menjadi diperluas, bukan berubah, untuk beberapa media telah sama sekali ditinggalkan, sementara banyak pilihan baru telah ditambahkan ke pelukis sebagai sebuah gambaran dalam berkarya secara lebih baik.

Untuk memulai pembahasan tentang lukisan, kita harus mendefinisikan beberapa permasalahan berkaitan dengan proses berkarya seni lukis. Dengan harapakan untuk memahami bagaimana, secara fisik berbagai macam media, dalam hal ini adalah media cat digambarkan seperti sebuah karya seni disatukan.

Cat terbuat dari pigmen, bubuk warna, dipergunakan dengan medium atau perekat, cairan yang memegang partikel pigmen bersama tanpa melarutkan mereka. Perekat pada umumnya bertindak sebagai atau termasuk pengikat, bahan yang menjamin 
Lukisan dinding paling terkenal dari abad ke-20 diciptakan Meksiko, di mana pemerintah revolusioner yang berkuasa pada tahun 1921 setelah satu dekade perang sipil ditugaskan seniman untuk menciptakan mural tentang Meksiko sendiri kemuliaan peradaban kuno, perjuangan politik, yang orang, dan harapan untuk masa depan.

Budaya Mixtec Adalah salah satu dari serangkaian lukisan dinding dicat oleh Diego Rivera di Istana Nasional di Mexico City. Orang Mixtec masih tinggal di Meksiko, seperti halnya keturunan semua peradaban awal daerah.

Kerajaan Mixtec dikenal karena seni mereka, dan Rivera memiliki digambarkan realitas sosial budaya masyarakat yang damai seniman di tempat kerja. Di sebelah kiri, dua laki-laki, sebagai bangsawan, sedang dilengkapi dengan tutup kepala ritual yang rumit, masker, dan jubah yang merupakan bagian penting dalam banyak kebudayaan kuno Meksiko. ke kanan, pandai besi yang mencair dan pengecor emas. Dalam kedepan-tanah adalah tembikar, pemahat, pekerja bulu, pembuat topeng, dan ahli Taurat. Dilatar belakang, orang ada panci emas dengan suasana alam di mana ada sungai.

\section{b. Encaustic}

Cat Encaustic terdiri dari pigmen dicampur dengan lilin dan resin. Ketika warma dipanaskan, lilin mencair dan cat dapat disikat dengan mudah. Ketika lilin mendingin, cat mengeras. Setelah lukisan selesai, mungkin ada akhir "terbakar di" sebagai sumber panas yang lewat di dekat permukaan cat-ing untuk memadukan warna.

Sumber-sumber sastra memberitahu kita bahwa encaustic adalah teknik penting dalam Yunani kuno (kata encaustic berasal dari bahasa Yunani untuk "terbakar di"). 
Encaustic lukisan, juga dikenal sebagai lukisan lilin panas, lilin dipanaskan dengan menggunakan lilin lebah yang berwarna ditambahkan pigmen. Cairan / pasta ini kemudian diterapkan pada permukaan - biasanya dibuat dari kayu, meskipun kanvas dan bahan lain yang sering digunakan.

Encaustic campuran yang paling sederhana dapat dibuat dari penambahan pigmen ke lilin lebah, tetapi ada beberapa resep lain yang dapat digunakan - beberapa jenis lain yang mengandung lilin, damar resin, minyak biji rami, atau bahan-bahan lainnya. Murni, bubuk pigmen dapat dibeli dan digunakan, meskipun beberapa campuran menggunakan cat minyak atau bentuk-bentuk pigmen.

Lukisan-lukisan encaustic awal untuk bertahan, bagaimanapun, adalah por-pemakaman ciri diciptakan selama abad pertama Masehi di Mesir, yang kemudian di bawah kekuasaan Romawi Potret seperti ini ditetapkan ke dalam casing tubuh mumi untuk mengidentifikasi dan mengenang orang mati. Warna lukisan ini, hampir segar sebagai hari mereka meletakkan, bersaksi kelanggengan encaustic. 
digunakan pada kedua sebelum dikupas atau kanvas mentah, dan juga di atas kertas dan kain.

Media ini dapat berlapis menjadi impasto berat seperti minyak atau diencerkan dengan air dan tersebar di tembus mencuci seperti cat air. Seperti tempera, mereka cepat kering dan permanen. (Seniman menggunakan akrilik biasanya beristirahat kuas dalam air saat bekerja, karena jika cat mengering pada sikat, sangat sulit untuk menghapus). Dengan demikian memberikan kemungkinan untuk bisa lebih mengembangkan gagasan selanjutnya.

\section{d. Tempera}

Lukisan Tempera merupakan lukisan yang dibuat di dinding (mural). Setelah tembok kering, catnya di aduk dengan bahan pelekat bahkan ada kalanya cat air dicampur dengan putih telur sehingga menghasilkan lukisan seperti cat minyak. Lukisan tersebut disebut juga Gauce. Lukisan Tempera banyak ditemukan di Eropa. Lukisan ini menjadi hiasan pada dinding Gereja dan Istana. Puncak kemegahan lukisan ini adalah pada zaman Renaisance.

Bahan tempera kualitas dengan baik cat air dan cat minyak. Seperti cat air, tempera adalah media berair. Seperti cat minyak, itu mengering untuk tangguh, tidak larut. Namun sementara cat minyak cenderung kuning dan gelap dengan usia, suhu warna mempertahankan kecemerlangan dan kejelasan mereka selama berabad-abad.

Secara teknis, tempera adalah cat yang merupakan emulsi, yaitu campuran stabil berair cair dengan minyak, lemak, lilin, atau resin. Sebuah contoh akrab emulsi adalah susu,yang terdiri dari menit tetesan lemak tersuspensi dalam cairan. Suatu derivatif susu yang disebut kasein adalah salah satu dari banyak kendaraan yang dapat digunakan untuk membuat tempera warna. 
Perekat tempera paling terkenal, bagaimanapun, adalah kuning telur yang bisa diandalkan dalam proses berkarya. Tempera mengering sangat cepat, sehingga warna tidak dapat dicampur dengan mudah setelah mereka ditetapkan.

Sementara suhu dapat diencerkan dengan air dan diterapkan dalam mencuci kuas, pelukis yang menggunakannya paling seperti biasanya mampu membangun bentuk secara bertahap dengan memberikan bentuk yang halus dan stroke bergerak pada sebuah permukaan kanvas, seperti gambar.

Secara tradisional, tempera digunakan pada dukungan panel kayu disiapkan dengan dasarnya, campuran pigmen putih dan lem yang disegel kayu dan bisa diampelas dan digosok dengan halus, seperti gading yang sudah selesai. Sebuah pelukis abad ke-20 yang telah dibudidayakan teknik-tempera klasik meskipun tidak pada panel adalah Andrew Wyeth. Lukisannya Gentleman Itu menunjukkan kualitas bercahaya medium terbaik mereka. 


\section{Glosarium}

Akrilik: Meskipun nama yang lebih tepat bagi mereka adalah cat polimer. Medium ini terdiri resin akrilik, polimerisasi (molekul yang sederhana terhubung ke rantai panjang) melalui emulsi dalam air.

Cat minyak : Terdiri dari pigmen diperparah dengan minyak, biasanya minyak biji rami.

Encaustic : Terdiri dari pigmen dicampur dengan lilin dan resin. Ketika warma dipanaskan, lilin mencair dan cat dapat disikat dengan mudah. Ketika lilin mendingin, cat mengeras.

Fresco : Pigmen yang dicampur dengan air dan diterapkan pada dukungan plester, sehingga memberikan kemungkinan itu dapat dilakukan,biasanya dinding atau langit-langit dilapisi di plester.

Tempera : Cat di kendaraan yang merupakan emulsi, yaitu campuran stabil berair cair dengan minyak, lemak, lilin, atau resin. 


\section{DAFTAR PUSTAKA}

1. Philip, Berrill. 2008. Everyone's Guide to Oil Painting, Berrill Philip Internasional Ltd. Terjemahan. Jakarta: Penerbit Akademia Jakarta.

2. Philip, Berrill. 2008. Everyone's Guide to Water Colour Painting. Berrill Philip Internasional Ltd. Terjemahan. Jakarta: Penerbit Akademia Jakarta.

3. Philip, Berrill. 2008. Everyone's Guide to Pastel Painting, Berrill Philip Internasional Ltd. Terjemahan. Jakarta: Penerbit Akademia Jakarta.

4. Junaedi Deni. 2016. Estetika Jalinan Subyek, Obyek dan Nilai, Yogyakarta: Penerbit Art Civ.

5. Sugiharto, Babang. 2015. Untuk Apa Seni. Bandung: Penerbit Matahari.

6. Data dari Internet http://en.wikipedia.org/wiki/Category:Painting_techniques http://theportraitplace.co.uk/arttechneg.php 


\section{BAB VIII \\ INTERPRETASI ALAM BENDA, FIGUR DAN LINGKUNGAN DALAM KARYA LUKISAN}

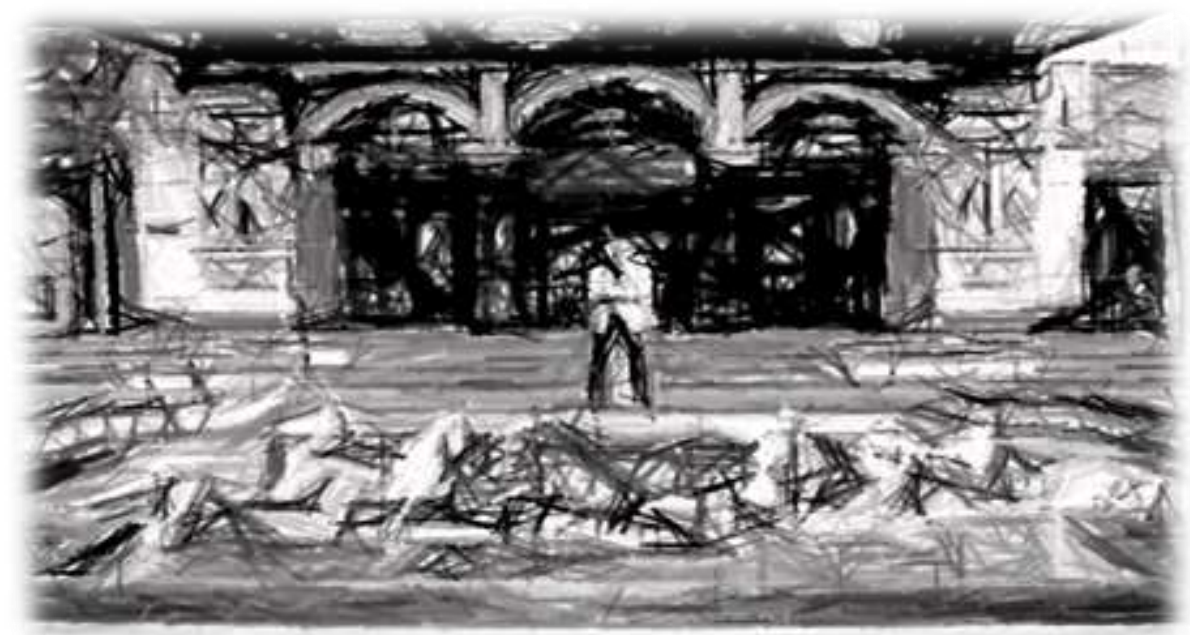

10 agaimana lukisan dengan mengunakan berbagai media? Dengan demikian seni lukis menjadi sebuah kesadaran baru bagi setiap orang yang melihat. Untuk dapat bisa melihat karya seni lukis menjadi sebuah permasalahan yang lebih mengembangkan pemikiran dan kesadaran.

Untuk itu bisa dilihat bahwa karya seni lukis itu menjadi kesadaran diri dan masyarakat dalam melihat permasalahan kehidupan masyarakat. Realitas sosial budaya itu menjadi sebuah kekuatan dalam perubahan didalam masyarakat.

Dalam pembelajaran ini lebih melihat permasalahan menjadi lebih luas berkaitan dengan seni lukis. Dalam proses pembuatan seni lukis dengan tahapan yang telah mencapai apa yang dilakukan dalam berkarya seni lukis. Berkaitan dengan 
masalah realitas sosial budaya memberikan kemungkinan pada pemahaman terhadap kesadaran dalam melihat karya seni lukis sebagai kekuatan dalam menangkapnya. Untuk itu perlu dilihat sejauh mana karya seni lukis itu mempunyai keterkaitan dengan karya seni lukis yang menjadi tugas dalam pembelajaran seni lukis.

Bagaimana seorang pelukis di dalam membuat karya lukisan mampu melakukan sebuah proses berkarya dengan pengetahuan seni yang lebih baik. Dengan demikian proses melukis bukan permasalahan bentuk lukisan saja, akan tetapi permasalahan cara pandang seorang pelukis terhadap realitas sosial budaya masyarakatnya, dimana seorang pelukis berada.

Mampu mengunakan makna dalam seni lukis, sehingga sesuai dengan tema alam benda, figur dan lingkungan realitas sosial budaya. Sebagai tranformasi yang ada dalam realitas sosial budaya dalam realitas kesenian. Seni lukis salah satu yang memberikan kemungkinan pada permasalahan yang ada dalam realitas sosial budaya.

Memahami media seni lukis dan menguasai teknik melukis menjadi bagian yang penting untuk membangun gagasan yang progresif, bahwa seorang pelukis mampu memberikan dimensi kehidupan di dalam realitas sosial budaya masyarakatnya. Dimana seorang pelukis berada didalam kehidupan masyarakatnya.

Dimana kesadaran berkarya menjadi besar untuk dapat lebih luas permasalahan realitas sosial budaya. Sebagai kajian dan perhatian untuk selalu diperjuangkan. Sebagai bentuk kepedulian seorang seniman terhadap permasalahan sosial budaya.

Mendiskusikan bagaimana tugas karya seni lukis sudah mencapai tujuan pembelajaran yang diinginkan. Berkaitan dengan permasalahan realitas sosial budaya sebuah kepedulian untuk selalu dipikirkan dan dihayati. Sebagai bentuk kepedulian terhadap lingkungan sekitarnya dimana dia berada. 
Dengan demikian kemampuan di dalam membuat karya seni lukis membawa seorang pelukis pada sikap berkesenian yang lebih konsisten terhadap apa yang dikerjakannya. Bahwa melukis bukan hanya sebagai kegiatan membuat karya lukisan, tetapi menjadi sebuah kegiatan pengetahuan yang memberikan konstribusi pada realitas kehidupan masyarakat. Seorang pelukis tidak bisa berdiri sendiri, akan tetapi dia menjadi bagian dari realitas sosial budaya masyarakat.

\section{Interpretasi Tema Lukisan}

Istilah interpretasi dalam kamus bahasa Indonesia adalah pemberian kesan, pendapat, atau pandangan teoritis terhadap sesuatu, tafsiran, karya lukisan merupakan hasil dari pandangan, taksiran dan pendapat seorang pelukis tentang obyek yang dilukiskannya.

Interpretasi sendiri dapat merujuk pada proses penafsiran yang sedang berlangsung atau berupa hasilnya. Suatu interpretasi merupakan bagian dari suatu presentasi atau penggambaran informasi yang diubah untuk menyesuaikan dengan suatu kumpulan simbol spesifik. Informasi itu dapat berupa lisan, tulisan, gambar, matematika, atau berbagai bentuk bahasa lainnya.

Seorang pelukis ketika berkarya dengan sebuah tema alam benda, figur dan lingkungan menjadi karya lukisan yang mempunyai pandangan, tafsiran dan pendapat seorang pelukis tentang obyek yang dikembangkan dan dieksplor. Gagasan dan kemampuan teknik yang melandasi dikemas dalam pengalaman seorang pelukis dalam mewujudkan karyanya.

Menjelaskan bagaimana mengunakan teknik seni lukis dalam berkarya mahasiswa dengan menginterpretasi sesuai tema alam benda, figur dan lingkungan realitas sosial budaya dalam beberapa karya yang dibuatnya. Membuat seorang pelukis mampu 
melihat setiap fenomena benda dan artefak sebagai sebuah tanda yang memberikan makna dan gambaran dari sebuah kehidupan realitas sosial budaya di dalam kehidupan masyarakatnya.

Begitu juga dengan dalam melihat masalah lingkungan selalu memberikan gambaran dari realitas sosial budaya yang sedang terjadi. Semua fenomena baik itu benda, figur dan lingkungan selalu berkaitan dengan realitas sosial budaya. Baik dalam membentuk dan mempengaruhi atau saling mempengaruhi menjadi sebuah perkembangan budaya yang ada di dalam kehidupan realitas masyarakatnya.

Lukisan alam benda memberikan interpretasi yang bersifat citra, simbolis, metafora dan mistis. Bentuk interpretasi tersebut antara lain; 1). Citra, 2). Metafora, 3). Simbol, 4). Mitos.

\section{Citra}

Citra adalah kombinasi antara titik, garis, bidang, dan warna untuk menciptakan suatu imitasi dari suatu objek-biasanya objek fisik atau manusia. Citra bisa berwujud gambar (picture) dua dimensi, seperti lukisan, foto, dan berwujud tiga dimensi, seperti patung. Menurut kajian psikologis berarti reproduksi mental, suatu ingatan masa lalu yang bersifat indrawi dan berdasarkan persepsi serta tidak bersifat visual.

Sedangkan menurut pendekatan semiotika atau ilmu tentang tanda, citra adalah sesuatu yang tampak oleh indra, tetapi tidak memiliki eksistensi substansial. Sebenarnya suatu citra itu terbentuk melalui suara(verbal) dan gambar(visual).

Tetapi menurut teoritikus sastra Ezra Pound, menerangkan bahwa citra bukan gambaran fisik, melainkan sebagai sesuatu yang dalam bentuk sekejab dapat menampilkan kaitan pikiran dengan emosi yang rumit. 
Metafora secara tradisional ditandai dengan tiga pilar pokok pertama: metafora merupakan sesuatu yang dikenakan pada benda maka untuk berabad-abad lamanya, metafora hanya diberikan dengan benda saja.

Kedua: metafora didefinisikan dalam konteks gerakan. Metafora dalam konteks ini dikenal dengan istilah Ephipora, adalah semacam perpindahan atau gerakan "dari...ke..." dalam konteks ini metafora berlaku untuk segala bentuk transposisi.

Metafora merupakan transposisi sebuah nama yang asing, yakni nama yang sebetulnya milik sesuatu yang lain. Berdasarkan penjelasan di atas metafora meliputi bentuk (visual, gerak atau kinetik) dan ucapan (verbal), sehingga metafora memakai mediamedia tersebut untuk menghasilkan makna baru dari suatu bentuk atau komposisi.

Menurut Paul Ricouer, dalam bukunya yang berjudul The Rule of Methapor (1977) mengungkapkan bahwa metaforis yang sebenarnya tidak pada kata (verbal) tidak pada kalimat bahkan tidak pada wacana melainkan pada kopula kata "adalah".

Kopula kata disini mengandung pengertian "adalah seperti" dan sekaligus "adalah bukan". Seperti pada kalimat "manusia adalah seekor babi" tentu bila kita berbicara metafora bukan berarti manusia itu sosok babi, disini metafora bekerja "adalah seperti" babi, yang mempunyai makna bahwa manusia itu berkelakuan kotor dan pemalas seperti babi.

Sehingga dalam konteks ini metafora berlaku dalam disiplin linguistik. Pendapat Paul Ricouer yang menempatkan metafora tidak pada kata, kalimat, atau benda (visual) maka kehadiran benda, kata, kalimat hanyalah sebagai sebuah presentasi dari fakta atau sistem.

Dalam konteks seni rupa, metafora merupakan bagian yang cukup penting dalam melukiskan, atau membuat makna baru 
dalam sebuah karya seni. Sebenarnya dalam konteks seni rupa intinya sama dengan konteks linguistik (verbal), hanya medianya yang berbeda yaitu dengan bentuk visual atau gambar. Dalam seni rupa metafora bekerja melalui peminjaman bentuk atau objek untuk menghasilkan sebuah makna.

Fungsi metafora dalam seni rupa, mungkin bekerja pada pengaburan makna yang ekstrim, negatif atau sebagainya. Misalkan pada sebuah karya seni lukis, dilukiskan seekor tikus dengan bentuk menyerupai manusia sedang membawa brankas uang atau kantong uang. Sehingga dalam lukisan tersebut dapat diartikan seorang manusia yang rakus akan uang atau duniawi.

\section{Simbol}

Simbol menurut wikipedia bahasa Indonesia, ensiklopedia bebas adalah gambar, bentuk, atau benda yang mewakili suatu gagasan, benda, ataupun jumlah sesuatu. Meskipun simbol bukanlah nilai itu sendiri, namun simbol sangatlah dibutuhkan untuk kepentingan penghayatan akan nilai-nilai yang diwakilinya. Simbol dapat digunakan untuk keperluan apa saja.

Simbolis, percaya bahwa seni harus bertujuan untuk menangkap kebenaran yang lebih mutlak yang hanya dapat diakses dengan metode tidak langsung dengan cara yang sangat metaforis dan sugestif, memberikan gambar tertentu atau objek dengan makna simbolis.

Estetika Simbol Budaya, keindahan yang berkaitan dengan nilai budaya setempat, di mana keindahan sebagai sebuah kesepakatan di dalam masyarakat atau suku bangsa tertentu. Simbol sebagai sebuah kesepakatan bukan sebagai sebuah tanda dari sesuatu yang ditandai.

Simbol Seni menurut Susanne K Langer adalah satu dan utuh, karena ia tidak menyampaikan makna untuk dimengerti, 
melalui simbol, tetapi simbol tersebut tidak terkonvensi di suatu kelompok dimana seniman itu hidup. Sehingga seniman dituntut kreativitasnya untuk menciptakan simbol baru, untuk menciptakan makna baru, maka dari itu simbol dapat bersifat personal.

Simbolisasi ini, telah terjadi dekontruksi pertandaan yang bersifat sewenang-wenang, menjadi permainan bebas tanda. Mengacu pada pemikirin Jaques Derrida, tokoh poststrukturalis, yaitu tentang dekonstruksi tanda untuk menghasilkan makna baru.

Menurut Derrida, bahwa petanda (makna) tidak harus diterima sebagai konvensi, ia harus dibongkar dan didekonstruksi. Selanjutnya hubungan antara penanda dan petanda tidak bersifat simetris atau baku, akan tetapi terbuka bagi permainan bebas tanda, sebuah permainan yang akan membawa pembaharuan.

Berkarya seni rupa seniman diberi kebebasan penuh untuk melukiskan simbol-simbol baru. Seniman dengan pola pikir yang berbeda diharapkan dapat menciptakan simbol-simbol baru melalui karyanya. Akan lebih kaya dengan bentuk atau objek visual yang baru.

Nilai simbolik dalam karya seni dapat berubah, tidak hanya berpatokan pada nilai konvensional masyarakat. Konsep tentang permainan bebas tanda ini relevan juga dengan teori dari pemikir post-strukturalis, Julia Kristeva. la menjelaskan tentang model pemaknaan, salah satunya adalah significance, yaitu pemaknaan yang menghasilkan makna-makna subversive dan kreatif, suatu proses penciptaan tanpa batas dan tak terbatas. Proses penyaluran kapasitas-kapasitas sebjektifvitas pada diri manusia melalui ungkapan bahasa.

\section{Mitos}

Mitos adalah khayalan atau sacara ilmiah adalah sejarah yang tidak benar. Mitos dipakai untuk mengalihkan makna pada 
suatu tempat atau bentuk, tetapi secara substansial dalam mitos itu tersimpan makna sebenarnya.

Menurut Roland Barthes, mitos adalah pengkodean makna dan nilai-nilai sosial (yang sebetulnya arbiter atau konotatif), sebagai sesuatu yang dianggap alamiah. Menurut Roland Barthes, mitos adalah nilai-nilai sosial dalam khidupan manusia, ketika kita berbicara kehidupan sosial kita, maka pada hari itu menjadi mitos. Disini dapat ditarik kesimpulan juga, bahwa mitos merupakan bahasa simbolik yang tidak beku dan berhenti, akan tetapi merupakan bahasa yang dapat menggairahkan dan sekaligus menyatukan nilai-nilai budaya.

Peran mitos menjadi sarana pencarian sudut pandang dalam pencapaian tujuan tertentu. Dan tentunya penyampaian makna dalam sebuah karya seni.

Sebuah kegiatan manusia di dalam kehidupan ini harus dibekali dengan kegiatan berpikir dan berbuat secara lebih baik. Karena kehidupan manusia semata-mata hanya jalani kehidupan di dunia ini, sehingga mendorong manusia untuk selalu melakukan kegiatan agar mencapai kehidupan yang lebih baik, sebagai sikap dari keberadaan kita di dunia ini.

Proses berpikir yang intinya mengingat kembali adalah membangun hubungan-hubungan sehingga benda atau kejadian yang ingin kita kenali berada kembali dalam suatu konstelasi dunia yang ada di dalam benak kita. Mengingat kembali adalah membiarkan daya ingat kita akan benda atau suatu kejadian dalam suatu "permainan-antara" yang memperlihatkan dirinya sendiri. Segala seuatu didalam kepala kita bermain seperti adanya. (Bagoes 2000: hal 111).

Untuk itu gagasan dan kreativitas sebagai awal dalam berbuat serta melakukan sesuatu merupakan satu kesatuan di dalam membuat karya seni lukis. Dengan demikian munculnya gagasan 


\section{Glosarium}

Citra : Kombinasi antara titik, garis, bidang, dan warna untuk menciptakan suatu imitasi dari suatu objek-biasanya objek fisik atau manusia. Citra bisa berwujud gambar (picture) dua dimensi, seperti lukisan, foto, dan berwujud tiga dimensi, seperti patung.

Interpretasi : Pemberian kesan, pendapat, atau pandangan teoretis terhadap sesuatu; tafsiran; karya lukisan merupakan hasil dari pandangan, taksiran dan pendapat seorang pelukis tentang obyek yang dilukiskannya.

Metafora : Sebuah model interaksi tanda, yang didalamya sebuah tanda dari sebuah sistem digunakan untuk men-jelaskan makna untuk sebuah sistem lainnya. Atau dengan kata lain meminjam bentuk, tulisan, atau verbal untuk menghasilkan makna baru melalui wujud yang lain.

Mitos : Khayalan atau sacara ilmiah adalah sejarah yang tidak benar. Mitos dipakai untuk mengalihkan makna pada suatu tempat atau bentuk, tetapi secara substansial dalam mitos itu tersimpan makna sebenarnya.

Partisipatoris : Ketertlibat seorang seniman dalam kehidup-an sosial budaya berkaitan dengan perubahan untuk mencapai masyarakat sejahteran dan berbudaya.

Proses berpikir : Mengingat kembali adalah membangun hubungan-hubungan sehingga benda atau kejadian yang ingin kita kenali berada kembali dalam suatu konstelasi dunia yang ada di dalam benak kita.

Simbol : Gambar, bentuk, atau benda yang mewakili suatu gagasan, benda, ataupun jumlah sesuatu. Meskipun simbol bukanlah nilai itu sendiri, namun simbol sangatlah dibutuhkan untuk kepentingan penghayatan akan nilai-nilai yang diwakilinya. Simbol dapat digunakan untuk keperluan apa saja. 
Teknik seni lukis : Kemampuan menguasai teknik melukis dengan baik, yang berkaitan dengan mempergunakan media dan mengembangkan pengetahuan teknik dengan media yang lain, sesuai dengan kemampuan dan perkembangan ide dan gagasan dari seorang pelukis. 


\section{DAFTAR PUSTAKA}

1. Nashori, Fuad. 2002. Mengembangkan Kreativitas Dalam Perpektif Psikologi Islam. Yogyakarta: Penerbit Menara Kudus

2. Peuresen, C.A.Van. 1976. Strategi Kebudayaan, Yogyakarta: Penerbit Kanisius.

3. Paul, Ricoeur. 2014 Teori Interpretasi, Yogyakarta: Penerbit IRCISoD.

4. Rusmana, Dadan. 2014. Filsafat Semiotika. Bandung: Penerbitan Pustaka Setia.

5. Read, Herbert. 2000. The Meaning Of Art. Terjemah Soedarso $S P$. Yogyakarta: Penerbit Duta Wacana University Press.

6. Sutrisno, Mudji dan Hendar Putranto. 2005. Teori-Teori Kebudayaan, Yogyakarta: Penerbit Kanisius. 
Seni Lukis, Kansep dan Metade 


\section{BAB IX \\ MEMPRESENTASIKAN KARYA LUKISAN}

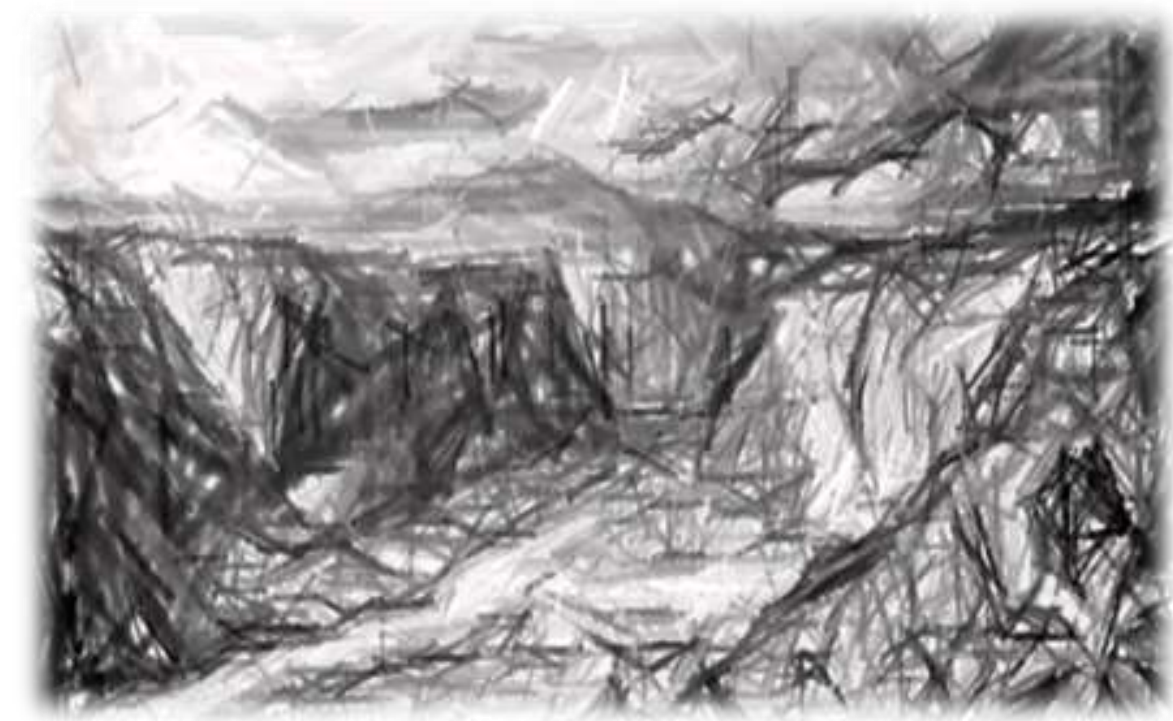

embuat karya seni lukis merupakan sebuah proses
interpretasi seorang pelukis terhadap obyek lukisan yang
dibuatnya dalam sebuah lukisannnya. Dengan demikian memberikan makna dalam seni lukis sesuai tema alam benda, figur dan lingkungan realitas sosial budaya. Dalam proses pembuatan seni lukis dengan tahapan yang telah mencapai apa yang dilakukan dalam berkarya seni lukis.

Bahwa seni lukis selalu berkaitan dengan masalah realitas sosial budaya memberikan kemungkinan pada pemahaman terhadap kesadaran dalam berkesenian. Mampu menumbuhkan kepekaan di dalam memahami permasalahan sebagai bentuk internalisasinya. Dengan demikian seni lukis yang dibuat dengan 
sendiri bersandar pada aspek realitas sosial budaya dari seorang pelukis.

Dimana karya seni lukis dengan sendiri akan sebagai kekuatan dalam menangkap permasalahan yang ada dalam kehidupan masyarakatnya. Untuk itu perlu dilihat sejauh mana karya seni lukis itu mempunyai keterkaitan dengan karya seni lukis yang menjadi tugas dalam pembelajaran seni lukis.

Dalam tahapan pembelajaran yang lebih melihat karya seni lukis bukan hanya sebagai proses berkarya. Tetapi juga mempunyai peran penting dalam kehidupan seorang pelukis yang berkaitan dengan pandangan hidup dan perkembangan kehidupannya.

Hal ini juga berkaitan dengan permasalahan kehidupan dengan masyarakat dan tanggung jawab sosial yang menjadikan seorang pelukis mempunyai tanggung jawab. Untuk bisa melukiskan kehidupan realitas sosial budaya yang ada di dalam kehidupannnya. Sebagai nilai kehidupan yang memang harus diperjuangkan.

Pembelajaran seni lukis dimulai dengan merepresentasikan karya seni lukis dari tugas yang telah diberikan. Diskusi sebagai pengembangan gagasan dan kreativitas dalam berkarya, tetapi juga sebagai pengembangan berkarya dan merasionalisasikan karya dalam sebuah pemahaman dan kesadaran dari proses berkarya seni lukis. Dari situ diharapakan semua mahasiswa dalam melihat karya seni lukis sendiri dengan berbagai aspek dalam diskusi tersebut.

Begitu juga akan memperkaya di dalam membuat dan memahami karya seni lukis sebagai sebuah ekspresi. Memberikan ruang juga pada setiap mahasiswa untuk mengungkapkan pikiran dan gagasan sehingga memberikan kemungkinan di dalam melihat karya seni menjadi lebih kaya dan bermakna lebih baik. 
mana menginterpretasikan tema itu dengan gagasan, yang menjadi konsep berkarya. Sebagai bentuk karya seni lukis berkembang sesuai dengan proses berkarya seni, sebagai bentuk berkeseniannya.

Seni lukis sebagai ekspresi seorang pelukis mempunyai muatan yang disadari maupun tidak mencerminkan kehidupan masyarakat. Realitas sosial budaya masyarakat itu yang memberikan warna yang direpresentasikan pada sebuah karya seni lukis. Sebagai proses yang selalu berkembang dari gagasan satu dengan gagasan berikutnya.

Membangun kesenian dalam pembahaman yang lebih satu dari realitas sosial budaya. Dasar berkesenian ini menjadi sesuatu tumbuh dan berkembang di masyarakat. Bahwa realitas sosial budaya bukan sebuah obyektitas dari sebuah realitas, tetapi juga bukan sebagai karya seni lukis realitas sosial yang mempunyai pemahaman ideologi komunisme.

Dengan demikian seni lukis bukan sebuah bentuk keindahan saja, tapi juga menjadi keindahan hidup dalam perkembangan masyarakatnya. Sebagai sebuah nilai yang berkaitan dengan kaidah, norma sebagai sebuah tradisi masyarakat yang mempunyai berbudi luhur, sebagai sikap dari masyarakatnya. Bahwa karya seni lukis memang sudah menjadi bagian kehidupan masyarakat. 


\section{Glosarium}

Pameran : Memamerkan karya seni lukis atau seni rupa dalam ruang pameran. Pameran itu membawa karya seni lukis dalam resepsi keindahan karya seni lukis dari makna yang ditangkapnya oleh masyarakat pada umumnya.

Mempresentasikan lukisan : Menyajikan, memamerkan, mengemukakan dalam sebuah diskusi pada kegiatan pameran seni lukis yang diakan secara bersama-sama dengan yang lain.

Seni lukis Realitas Sosial Budaya : Sebagai sebuah konsep seni mempunyai bentuk keindahan, yang memberikan pengetahuan apa yang diungkapkan seorang pelukis. Sebagai sesuatu apa yang sedang ada di dalam kehidupan masyarakat yang berada dalam kehidupan realitas sosial budaya. 


\section{DAFTAR PUSTAKA}

1. Philip, Berrill. 2008. Everyone's Guide to Oil Painting, Berrill Philip Internasional Ltd. Terjemahan. Jakarta: Penerbit Akademia Jakarta.

2. Philip, Berrill. 2008. Everyone's Guide to Water Colour Painting. Berrill Philip Internasional Ltd. Terjemahan. Jakarta: Penerbit Akademia Jakarta.

3. Philip, Berrill. 2008. Everyone's Guide to Pastel Painting, Berrill Philip Internasional Ltd. Terjemahan. Jakarta: Penerbit Akademia Jakarta.

4. Nashori, Fuad. 2002. Mengembangkan Kreativitas Dalam Perpektif Psikologi Islam. Yogyakarta: Penerbit Menara Kudus

5. Peuresen, C.A.Van. 1976. Strategi Kebudayaan, Yogyakarta: Penerbit Kanisius.

6. Sutrisno, Mudji dan Hendar Putranto. 2005. Teori-Teori Kebudayaan, Yogyakarta: Penerbit Kanisius. 
Seni Lukis, Kansep dan Metade

304 
dalam mengembang seni lukis sebagai sesuatu yang berarti bagi masyarakatnya.

Menumbuhkan kesadaran dalam membuat karya lukisan berbasis realitas sosial budaya. Membangun kesadaran mahasiswa pada masalah realitas sosial budaya. Untuk bisa melihat seni lukis sebagai bagian dari kehidupan masyarakat di mana kehidupan mengalami dinamika realitas sosial budaya. Yang menjadi kepedulian terhadap permasalahan realitas sosial budaya.

Mendiskusikan bagaimana tahapan-tahapan dalam berkarya dalam teknik dengan baik. Membuat mahasiswa dapat karya seni lukis bukan hanya bisa melukis, tapi juga bisa menjelaskan tahapan-tahapan di dalam berkarya seni lukis.

Bahwa karya seni lukis bukan semata-mata sebagai lukisan yang bertemakan alam benda, figur, pemandangan alam, lingkungan. Tapi memang menjadi sebuah kesadaran seorang pelukis dalam melihat permasalahan realitas sosial budaya menjadi bagian dalam seni lukisnya.

Untuk dapat melihat seni lukis sebagai realitas sosial budaya masyarakat yang mempunyai peran dalam perkembangan masyarakat. Karya seni lukis yang dimunculkan memang lahir dari detak kehidupan masyarakatnya. Seni lukis sebagai tahapan yang mendasari teknik melukis untuk melihat dan menangkap realitas sosial budaya masyarakat. Membuat seorang pelukis sejalan dengan detak perkembangan masyarakat dan zamannya, sebagai artikulasi seorang pelukis.

\section{Seni Lukis Berbasis Realitas Sosial Budaya}

Menjelaskan kesadaran di dalam berkarya seni lukis selalu mempunyai dasar berpikirnya. Bahwa melukis bukan pada sandaran bentuk, tapi pada gagasan yang membentuk karya seni lukisa. Sebagai kesadaran baru dalam bentuk yang ada dalam 
lukisan tersebut. Sehingga membuat karya lukisan berbasis realitas sosial budaya. Memberikan nuansa kehidupan seorang pelukis di lingkungan masyarakat di mana dia tinggal.

Menggambarkan seorang pelukis di dalam berkarya seni lukis tidak lepas dari realitas sosial budaya di mana dia berada. Hal ini berkaitan dengan sifat dan fitrah manusia yang lahir dari realitas sosial budaya yang ada pada orang tua atau keluarganya. Keluarga merupakan kelompok terkecil dari kehidupan realitas sosial budaya yang ada dalam kehidupan masyarakatnya.

Realita sosial budaya sebagai sebuah sistem yang ada di dalam masyarakat menjadi sebuah gambaran dari realitas kehidupan. Pandangan dan pemikiran masalah realitas sosial budaya yang menjadi kajian ilmu pengetahuan sosial. Dengan adanya cultural studies sebagai teori sosial budaya yang sedang berkembang, untuk itu kita bisa melihat formasi dari sosial budaya dalam perkembangannya.

Untuk Althusser formasi sosial bukan sebagai suatu totalitas di mana kebudayaan menjadi ekspresi, namun sebagai suatu struktur kompleks dari berbagai hal (berbagai level atau praktik) yang 'dominannya terstruktur'. Jadi, aspek-aspek politik, ekonomi dan ideologi yang berbeda-beda diartikulasikan bersama-sama untuk membentuk satu kesatuan.

Realitas sosial budaya yang bukan merupakan hasil dari determinasi berbasis suprastruktur yang tunggal dan searah, melainkan hasil dari determinsi yang muncul dari level yang berbeda sehingga suatu formasi sosial adalah hasil dari overdeterminasi.

Seni lukis diformasikan dalam realitas kehidupan realitas sosial budaya masyarakatnya. Dilakukan dalam dunia pendidikan sebagai formasi yang dapat memberikan kontribusi lebih baik. Meskipun tidak bisa dipungkiri seni lukis berbasis realitas sosial 
budaya yang berkembang di masyarakat juga menjadi bagian yang tidak kalah penting meski pengetahuan seni lukis yang berkembang dimasyarakatkan disebut dengan seni tradisi.

Seni lukis itu juga dilihat dari pengetahuan teknik dan media yang dipergunakan oleh masyarakat tertentu. Seperti seni lukis batik, dengan mempergunakan media lilin yang disebut dengan malam, canting sebagai kuasnya, untuk melukis diatas kain. Melukis dengan pola yang telah ditentukan dikenal dengan batik. Sebuah terminologi batik bukan menyangkut pada bentuk dan media tapi juga filosofinya.

Seni lukis sebagai makna kehidupan yang mempunyai akar realitas sosial budaya yang kuat. Begitu juga dengan seni lukis Bali dengan yang khas dengan menggambil tema keagamaan dan keseharian. Mempergunakan media bambu dengan kain dan warna yang dipergunakan dengan warna alam. Memperlihatkan bahwa seni lukis berkembang pada basis realitas sosial budaya masyarakat setempat.

Begitu juga masalah teknik dengan sendiri berkembang sesuai dengan realitas sosial budaya yang ada. Meskipun dalam masyarakat tertentu, dalam hal ini media seni lukis didasarkan pada pengetahuan seni dari realitas sosial budaya modern. Namun dalam proses berkesenian teknik dan meterial dengan sendiri menjadi satu kesatuan yang pada dari kebutuhan mahasiswa sebagai seorang pelukis yang didasarkan pada gagasan dan pengalaman hidupnya.

Untuk itu dalam pembelajaran seni lukis seiring dengan perkembangan zaman, seni lukis yang berkembang dengan baik dari pendidikan seni menciptakan seni lukis formal. Namun di dalam pendidikan formal seni lukis bukan hanya sebagai bentuk formal, belajar pada masalah teknik dan penguasaan bentuk dalam melukis. 
Tapi pembelajaran melukis itu lebih jauh menyentuh nilai kemanusian yang mempengaruhi kehidupan seseorang dan realitas sosial budaya dan perkembangan kehidupan sosial. Membuat seni lukis meliputi pemahaman dan pengetahuan tentang nilai kreativitas, spiritual, rasa kemanusian yang tinggi guna membangun tatanan kehidupan sosial masyarakat yang lebih baik.

Semiotika, sebagai sebuah sistem tanda dalam karya lukisan memberikan makna pada konsep gagasan seni lukis dari perkembangan realitas sosial budaya yang ada di masyarakat. Dalam melihat perpektif yang ada di dalam kehidupan masyarakat, dalam sebuah karya lukisan.

Hal ini bisa dilihat dalam filsafat semiotika sebagai paradigma dan kerangka kerja berpikir yang logis, radikal, dan non emperis berobyekkan tanda-tanda pada ranah alam budaya, politik dan lainnya (Dadan Rukmana, 2014:24)

\section{Menguasai Teknik Seni Lukis}

Selanjutnya akan menjelaskan teknik di dalam berkarya seni lukis. Kemampuan seni lukis yang baik karena kemampuan memahami dan mengenal media dan teknik menjadi bagian dirinya. Dengan begitu akan memberikan keluasan pada gagasan dan pengembangan ide yang lebih baik, bukan hanya sekedar melukis.

B.S.Myers sendiri melihat seni teknik, dia menjelaskan, Teknik seni lukis merupakan tebaran pigmen atau warna cair pada permukaan bidang datar (kanvas, panel, dinding,kertas) untuk menghasilkan sensasi atau ilusi keruangan, gerakan, tekstur, dan bentuk. Sama baiknya dengan tekanan yang dihasilkan kombinasi unsur-unsur tersebut.

Tentu saja hal itu dapat dimengerti, bahwa melalui alat teknis tersebut dapat mengekspresikan emosi, ekspresi, simbol, 
Fumo harfiah berarti "naik dalam asap" diturunkan untuk makna Italia. Sfumato adalah teknik lukisan di mana tidak ada garis keras, dan itu dicat dengan sapuan yang meningkatkan penuh warna dan cahaya. Daerah menyatu dalam lukisan, sebagai kesatuan teknik dan gagasan seni lukis. Karya lukisan yang lembut dalam membentuk figur dengan pengarapan volume anatominya.

Maka istilah "Sfumato" digunakan oleh Michael J. Gelb bukunya Bagaimana Berpikir Seperti Leonardo da Vinci untuk menggambarkan salah satu kemampuan mental Leonardo da Vinci, yaitu kemampuan untuk memegang dua ide paradoks dalam pikiran seseorang tanpa kesulitan.

Dia menunjukkan bahwa itu adalah komponen penting dari keterbukaan pikiran karena memungkinkan seseorang untuk memegang perspektif yang berbeda pada waktu yang sama dan karena itu menghindari bias belakang. Sfumato membuka dimensi baru untuk pemecahan masalah, inspirasi mencari, dan melihat pola-pola baru sambil berpikir tentang ambiguitas, ide-ide dan sistem paradoks berpikir.

\section{c. Teknik Seni Lukis Cangiante}

Cangiante adalah salah satu dari empat mode lukisan kanonik dari Renaissance (tiga lainnya adalah Unione, Chiaroscuro, dan Sfumato). Kata itu sendiri berasal dari cangiare Italia ("mengubah").

Cangiante ditandai dengan pelukis yang merubah menjadi berbeda, lebih ringan, rona ketika rona wajah asli tidak dapat dibuat cukup ringan atau, sebaliknya, mengubah rona wajah gelap ketika rona wajah asli tidak dapat dibuat cukup gelap.

Pelukis bisa merubah, misalnya dari warna kuning ke warna merah (terlepas dari warna sebenarnya benda) ketika lukisan bayangan pada objek kuning hanya karena kuning ia harus bekerja 
dengan tidak dapat dibuat cukup gelap untuk membuat bayangan pada yang objek (dan kaleng merah).

Ada, untuk memastikan, metode lain bayangan render (atau high light), namun, sering, prosedur yang tersedia (pencampuran warna asli dengan warna hitam atau coklat) akan membuat warna bayangan kusam, memberikan mungkin niat pelukis untuk membuat, dan bahkan bayangan dalam warna yang lebih murni.

Satu hal yang juga harus diingat bahwa, dalam Renaissance, warna yang tersedia sangat terbatas dalam jumlah dan jenis. Hal ini yang menjadi sebuah pertimbangan bagi seorang pelukis dalam membuat karya lukisan. Dengan mempertimbangkan warna dan teknik melukis yang dipergunakan, serta obyek atau figur yang akan dilukiskan.

Sejalan dengan apa yang menjadi keinginan seorang pelukis untuk melukiskan figur yang dia inginkan. Dari situ juga bisa dilihat bahwa teknik karya seni lukis yang lahir tidak lepas dari realitas sosial budaya yang berkembang pada saat ini. Sebagai sebuah pertimbangan dalam membuat karya seni lukis yang dihasilkannya. 


\section{e. Teknik Seni Lukis Chiaroscuro}

Chiaroscuro juga merupakan istilah teknis yang digunakan oleh seniman dan sejarawan seni untuk menggunakan kontras cahaya untuk mencapai rasa volume dalam pemodelan obyek tiga dimensi seperti tubuh manusia. Efek serupa dalam pencahayaan sinema dan fotografi juga sering disebut chiaroscuro.

Lebih lanjut terkait penggunaan khusus istilah termasuk chiaroscuro ukiran kayu, ukiran kayu berwarna untuk dicetak dengan blok yang berbeda, masing-masing menggunakan tinta warna yang berbeda, dan chiaroscuro gambar untuk gambar di atas kertas berwarna dengan menggambar di media gelap dan penyorotan putih.

Chiaroscuro berasal selama Renaissance seperti menggambar di atas kertas berwarna, di mana seniman bekerja dari nada dasar kertas terhadap cahaya menggunakan putih guas, dan menjelang gelap menggunakan tinta, body colour atau cat air.

Karya lukisan ini pada gilirannya menarik pada tradisi dalam diterangi manuskrip, akan kembali ke akhir naskah Imperial Romawi di ungu - dicelup vellum. Karya-karya tersebut biasa dipanggil "chiaroscuro gambar", tetapi lebih sering digambarkan dalam terminologi modern museum dengan rumus seperti "pena di atas kertas disiapkan, meningkat dengan bentuk warna putih".

Chiaroscuro ukiran kayu dimulai sebagai imitasi dari teknik ini. Ketika mendiskusikan seni Italia, istilah ini kadang-kadang digunakan untuk berarti gambar dicat dengan warna monokrom atau dua, lebih umum dikenal dalam bahasa Inggris oleh setara Perancis, grisaille. Istilah awal diperluas dalam arti untuk menutupi semua kontras yang kuat dalam pencahayaan antara daerah terang dan gelap dalam seni, yang sekarang makna utama.

Penggunaan lebih teknis dari istilah chiaroscuro adalah efek dari pemodelan cahaya dalam lukisan, gambar atau seni grafis, di 
mana dimensi volume tiga disarankan oleh nilai gradasi warna dan pembagian analitis cahaya dan bayangan bentuk sering disebut "shading". Penemuan efek ini di Barat, "skiagraphia" atau "bayangan-lukisan" ke Yunani Kuno, secara tradisional dianggap berasal dari pelukis Athena terkenal dari abad ke-5 SM, Apollodoros .

Meskipun hampir tidak ada lukisan Yunani kuno bertahan, pemahaman mereka tentang efek pemodelan cahaya masih dapat dilihat pada akhir abad ke-4 SM mosaik Pella, Makedonia, khususnya Deer Hunt, di Rumah Penculikan Helen, tertulis gnosis epoesen, atau 'pengetahuan melakukannya'.

Mereka juga bertahan dalam bentuk standar yang agak mentah di seni Bizantium dan disempurnakan kembali pada Abad Pertengahan untuk menjadi standar pada awal abad kelima belas dalam lukisan dan pencahayaan naskah di Italia dan Flanders, dan kemudian menyebar ke seluruh seni Barat.

The Raphael lukisan ilustrasi, dengan cahaya yang datang dari kiri, menunjukkan kedua model chiaroscuro halus untuk memberikan volume pada tubuh model, dan juga chiaroscuro yang kuat dalam arti lebih umum dalam kontras antara model remang dan latar belakang sangat gelap dedaunan.

Namun lukisannya terasa menjadi lebih rumit, yang chiaroscuro komposisi dari kontras antara model dan latar belakang mungkin tidak digambarkan dengan menggunakan istilah ini, sebagai dua elemen hampir sepenuhnya terpisah. Istilah ini umumnya digunakan untuk menggambarkan komposisi di mana setidaknya beberapa elemen utama dari komposisi utama menunjukkan transisi antara terang dan gelap, seperti di Baglioni dan Geertgen tot Sint Jans lukisan digambarkan di atas dan di bawah.

Pemodelan Chiaroscuro sekarang diambil untuk diberikan, tapi memiliki beberapa lawan, Inggris potret miniaturis Nicholas 
dalam tahap awal pekerjaan, karena membantu pelukis menjalin hubungan nilai dari gelap ke terang. Memperjelas satu kesatuan obyek lukisan yang dibuatnya.

Hal ini paling berguna dalam pendekatan klasik lukisan tidak langsung, di mana gambar dan underpainting ditetapkan sebelumnya dan dibiarkan kering. Lapisan berturut warna tersebut kemudian diterapkan dalam transparan glasir atau lapisan semitransparan. Membuat karya lukisan tersebut menjadi lebih terlihat natural, dengan dimensi ruang yang terbentuk.

Dalam kenyataannya seniman atau seorang pelukis yang menggunakan pendekatan ini mungkin akan melukis lapisan negatif membentuk di atas satu sama lain. Misalnya, menyiapkan imprimatura berwarna cukup gelap. Untuk mendapat karya lukisan yang diinginkan dalam bentuk warna yang diperhitungkan.

Kemudian, menggunakan setengah warna kulit, bentuk negatif wilayah soket mata yang dalam bayangan (yaitu semua yang tersisa dari imprimatura gelap adalah bahwa yang ada di dalam area gelap mata). Menangkap dalam suasana obyek yang dibuatnya, sehingga lukisan itu terasa suasana yang ingin ditangkap dan dirasakan seorang pelukisnya.

Selama obyek lukisan yang dibuat menjaga warna kulit setengah cukup tipis membuat obyek lukis itu dapat menyebar dengan cara luar obyek yang pada akhirnya akan menjadi model wajah dan kemudian mengambil warna yang sangat keren dengan bentuk negatif profil wajah keluar dari itu. Karya seni lukis.

Kemungkinan dalam melihat bentuk dan warna dari obyek lukisan tersebut. Hanya menggambarkan kemampuan dalam melihat obyek dalam sebuah karya lukisan. Kemampuan teknik di dalam melukis memang menjadi prasyarat, untuk bisa melihat karya seni lukis itu baik atau tidak. Memberikankan kemungkinan pada warna- warna yang dibuatnya. 


\section{J. Teknik Seni Lukis Anamorfisme}

Teknik Seni Lukis Anamorfisme, cara penggambaran dari sudut pandang, perspektif yang mengalami perubahan. Sebagai bentuk karya seni lukis yang dilihat dari arah tertentu, dengan pengolahan bentuk yang dibuatnya dalam sebuah lukisan. Untuk menghasilkan karya seni lukis berpadu dengan lingkungan atau arsitektural dari bentuk ilusi visual. Ketika seseorang memasuki ruang tertentu dengan sudut padang yang tepat, akan melihat karya lukisan itu menjadi satu kesatuan dari realitas ada. Seperti karya lukisan mural dan karya lukisan tiga dimensi.

\section{K. Teknik Seni Lukis Trompe-L'oeil}

Teknik Seni Lukis Trompe-L'oeil adalah teknik yang digunakan dalam penggambaran obyek-obyek tertentu yang ditujukan terutama untuk menciptakan ilusi mengenai keluasan ruang. Para pelukis di masa Renaisans, mengkombinasikan teknik ini dalam lukisanya dalam mengganggu persepsi mengenai batas antara imaji dengan kenyataan, misalnya gambar sebuah obyek yang terkesan menempel atau melayang diatas gambaran lain. (Bambang Sugiharto 2015:105)

\section{Teknik Seni Lukis Automatisme}

Teknik Seni Lukis Automatisme adalah teknik untuk menciptakan efek visual yang bersifat spontan, mengalir dan tak terduga yang dicapai melalui kebebasan tangan dan karakater material (cat atau pigmen) tanpa melibatkan pikiran sadar. Automatisme merupakan teknik yang amat mensyaratkan pentingnya memfokuskan diri terhadap dorongan bahwa sadar tanpa berniat menciptakan sesuatu yang artistik terlebih dahulu, melainkan sepenuhnya didorong secara murni oleh keadaan 


\section{Glosarium}

Automatisme Teknik lukis untuk menciptakan efek visual yang bersifat spontan, mengalir dan tak terduga yang dicapai melalui kebebasan tangan dan karakater material (cat atau pigmen) tanpa melibatkan pikiran sadar.

Cangiante : Ditandai dengan pelukis yang merubah menjadi berbeda, lebih ringan, rona ketika rona wajah asli tidak dapat dibuat cukup ringan atau, sebaliknya, mengubah rona wajah gelap ketika rona wajah asli tidak dapat dibuat cukup gelap

Chiaroscuro : Teknis seni lukis menggunakan kontras cahaya untuk mencapai rasa volume dalam pemodelan obyek tiga dimensi seperti tubuh manusia.

Impasto : Teknik lukisan di mana cat dilapiskan dengan sangat tebal di atas kanvas sehingga arah goresan sangat mudah terlihat. Imprimatura : Teknik lukisan, yang berarti sebuah noda awal warna dicat di tanah Ini memberikan pelukis dengan transparan, tanah kencang, yang akan memungkinkan cahaya yang jatuh ke lukisan untuk mencerminkan melalui lapisan cat.

Nocturne : Teknik lukisan yang menggambarkan adegan menggugah malam atau subyek seperti yang muncul dalam tabir cahaya, di senja, atau jika tidak ada cahaya langsung.

Repoussoir : Obyek sepanjang depan kanan atau kiri yang mengarahkan mata pemirsa ke dalam komposisi oleh bracketing ( framing ) tepi.

Sfumato : Teknik lukisannya yang melapiskan warna-warna yang berdekatan untuk menciptkan ilusi kedalaman, volume, dan bentuk. Tenebrisme : Lukisan dengan teknik ini menggunakan kontras yang sangat kasar dalam gradasi gelap ke terang. 
Trompe-L'oeil : Teknik lukis yang digunakan dalam penggambaran obyek-obyek tertentu yang ditujukan terutama untuk menciptakan ilusi mengenai keluasan ruang.

Unione : varian dari teknik - teknik yang sebelumnya. Dengan demikian memberikan kemungkinan bagi seorang pelukis untuk bisa melihat teknik sebagai sebuah tanda dari interpretasi media dan elemen seni rupa yang menjadi bagian dari karya seni lukis. 


\section{DAFTAR PUSTAKA}

1. Philip, Berrill. 2008. Everyone's Guide to Oil Painting, Berrill Philip Internasional Ltd. Terjemahan. Jakarta: Penerbit Akademia Jakarta.

2. Philip, Berrill. 2008. Everyone's Guide to Water Colour Painting. Berrill Philip Internasional Ltd. Terjemahan. Jakarta: Penerbit Akademia Jakarta.

3. Philip, Berrill. 2008. Everyone's Guide to Pastel Painting, Berrill Philip Internasional Ltd. Terjemahan. Jakarta: Penerbit Akademia Jakarta.

4. Sugiharto, Babang. 2015. Untuk Apa Seni. Bandung: Penerbit Matahari.

5. Data dari Internet

- http://reddamuralart.wordpress.com

- http://ranaberita.com/?p=303

- www.oktomagazine.com/arsip

- highered.mcgraw-hill.com/sites/.../GetleinCh7.

- http://en.wikipedia.org/wiki/Category:Painting_techniques

- http://theportraitplace.co.uk/arttechneg.php 
Seni Lukis, Kansep dan Metade 


\section{BAB XI \\ PAMERAN KARYA SENI LUKIS}

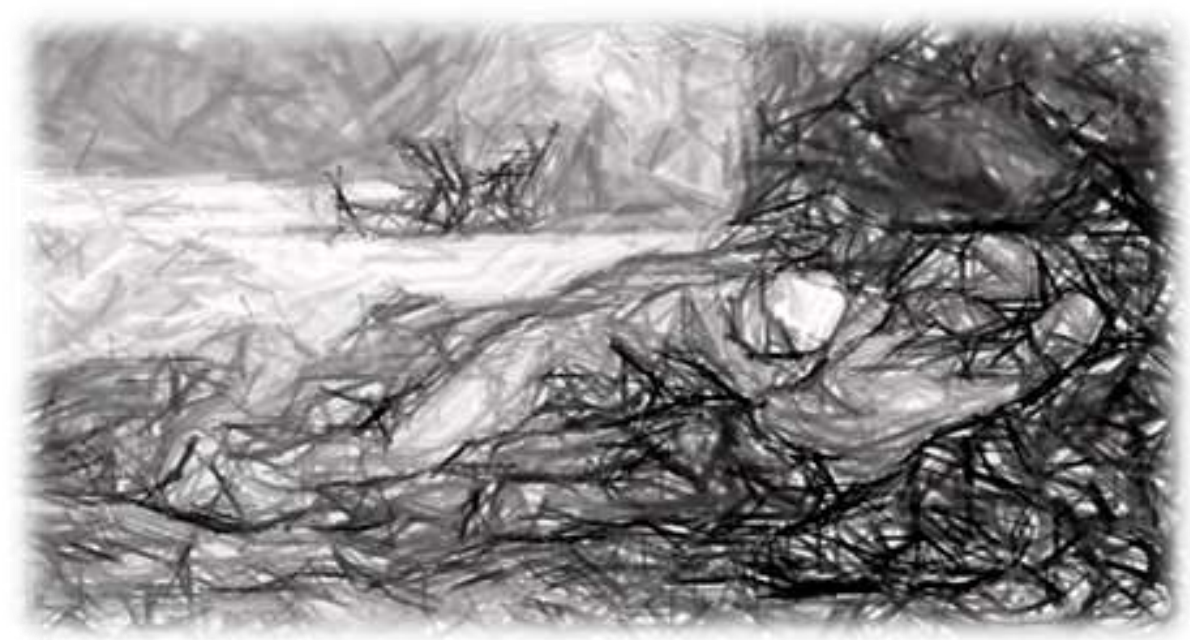

W $\begin{aligned} & \text { arya seni lukis dalam sebuah kesadaran berkesenian } \\ & \text { menumbuhkan kesadaran dalam membuat karya lukisan } \\ & \text { berbasis realitas sosial budaya. Kesadaran yang telah }\end{aligned}$ tertanam dari proses berkarya seni lukis ini membawa pada satu pandangan seni lukis itu bagian dari pembelajaran yang dipelajari dengan pendekatan berbasis realitas sosial budaya. Untuk dapat melihat permasalahan sosial bukan sebagai sebuah tema dari permasalahan seni lukis, berkaitan dengan teknik membuat karya seni lukis.

Bahwa karya seni lukis bukan sebuah karya seni lukis sebagai bentuk yang monolit, tunggal atau berdiri sendiri. Tapi karya itu lahir dari sebuah keterkaitan dengan berbagai macam hal, baik disadari maupun tidak. Untuk menyadarkan bahwa seni lukis sebagai landasan seorang pelukis melihat dan membuat karya seni secara lebih terbuka dalam berbagai macam hal. 
Seni lukis sebagai sebuah konsep seni mempunyai bentuk keindahan, di mana keindahan itu sebagai bagian dari elemen seni yang memberikan pengetahuan apa yang diungkapkan seorang pelukis. Dan memberikan tanda sebagai sesuatu apa yang sedang ada di dalam kehidupan masyarakat yang berada dalam kehidupan realitas sosial budaya. Memberikan transformasi budaya seni lukis dalam realisasi karyanya.

Dengan demikian kehidupan masyarakat memberikan warna kehidupan realitas sosial budaya masyrakatnya. Seni lukis juga yang memberikan kemampuan dalam kehidupan masyarakatnya. Seni lukis sebagai sebuah nilai yang dapat memberikan pengalaman dan pengembangan realitas sosial budaya dalam kehidupan masyarakatnya. Sebagai budaya yang tumbuh berkembang dalam realitas sosial membentuk pemahaman seni sebagai hasil karya mewarnai kehidupan masyarakat.

Dengan tatanan kehidupan yang harmonis dari berbagai macam keanek ragaman adat istiadat dan budaya. Dalam kerangka seni sebagai satu kesatuan dari nilai tradisi yang mengikat dalam satu kesatuan dari sebuah masyarakat dan bangsa yang bhineka tunggal ika.

Dalam beberapa kali pertemuan dengan materi pembelajaran yang telah dijelaskan. Memerlukan sebuah evaluasi untuk mengetahui sejauh mana materi pembelajaran itu sudah mencapai tujuan dari pembelajaran. Dalam melihat sebuah rangkaian materi itu bukan hanya sebagai sebuah pemahaman saja, tapi bagaimana menjadi sebuah sikap berkarya seni lukis. Bahwa melukis selain mempunyai kemampuan teknik dan mempunyai sentuhan keindahan dalam ekspresikan ide dan gagasan dalam sebuah karya seni lukis.

Seni lukis sebagai bagian dari kehidupan realitas sosial budaya dengan semangat dan spirit berkarya. Membuat ujian 
kesatuan dari sebuah gagasan pameran yang memperjelaskan pemahaman dan pengembangan dari sebuah perjalan seni lukis.

Kegiatan pameran mengalami perkembangan yang sangat signifikan dalam perkembangan seni pada saat ini. Menyelenggarakan sebuah pameran layak seperti membuat karya seni, di mana materi pameran, karya seni lukis atau karya seni lainnya menjadi bagian yang sangat diperhitungkan selain masalah ruang, desain ruang, lampu, desain lampu, lantai dan atapnya, ruang interior dan eksterior di dalam membuat pameran itu menjadi sesuatu yang berbicara, sebagai visi dari sebuah pameran, dalam hal ini menyelenggaran pameran yang dikenal dengan seorang kurator. Sebuah pameran menjadi bagian dari proses membuat karya seni. Kurator bukan lagi seorang yang mengerjakan penyelenggaraan pameran tetapi sebagai pengagas dari sebuah pameran dengan visi yang ingin disampainya. Layaknya seperti seorang pelukis yang membuat karya seni lukis dengan gagasan berkaryanya.

Menjelaskan kesadaran di dalam berkarya seni lukis selalu mempunyai dasar berpikirnya. Sehingga membuat karya lukisan berbasis realitas sosial budaya bisa dimengerti. Konsep adalah mempresentasikan karya lukisan berbasis realitas sosial budaya. Sebagai kelanjutan dari sebuah gagasan dan kreativitas di dalam berkarya seni lukis.

Basis realitas sosial budaya menggurai menjadi bentuk yang menjelaskan karya seni lukis, media dan gaya yang dipresentasikan dalam ruang pameran. Nampak menjadi lebih kuat dan sempurna dalam pameran itu. Hal ini tidak lepas bahwa seorang pelukis setidaknya harus melangkah sebagai "kuratorial" dari karya sendiri dan karya yang lain kalau memang itu menjadi bagian tugasnya. 
Salah satu perintis kekuratoran yang berfokus pada pameran dan pengeloksian seni rupa modern adalah Alfred $\mathrm{H}$. Barr Jr mengepalai Museum of Modern Art (MoMA), institusi yang berpengaruh dalam seni rupa modern. Pada masa kepemimpinan di MoMA, Barr dikenal melalui dua pameran penting yang ia selenggarakan pada tahun 1936, Cubism and Abstract Art dan Fantastic Art, Dada and Surrealism (Kantor, 2002;314). Salah satu yang dalam pameran-pameran Barr adalah upayanya untuk memberikan informasi historis, tidak hanya kepada masyarakat atau pengunjung museum, tapi juga kepada para seniman, khususnya mereka yang aktif pada tahun 1930an.

Dalam dua pameran tersebut, konteks historis dibatasi ke dalam kronologi perkembangan gaya yang mengabaikan semua aspek sosial, perubahan politik, atau psikologis lainnya. Kedua pameran tersebut disuguhkan dalam tradisi keilmuan akademik, lengkap dengan dokumentasi arsip dan foto-foto yang menyertainya.

Kedua pameran tersebut sangat pengaruh dalam dunia kritik seni hingga 1960-an, dan menjadi sumber dalam tema-tema tentang modernisme yang dikembangkan oleh kritikus Clement Greenberg (Agung Hujaknikajennong, 2015; 115-116).

Mempresentasikan karya lukisan dalam sebuah pameran, bukan sekedar menunjukan hasil karya seni lukis yang dibuatnya. Tetapi merupakan perjalanan gagasan dan kreativitas dalam pemahaman pada tema seni lukis yang berbasis realitas sosial budaya. Aspek ini yang ada di dalam kehidupan masyarakat, meskipun kadang hal itu ada kesenjangan dan pemahaman yang berbeda dalam melihat permasalahan yang sama. Dalam sebuah pameran yang memberikan banyak kemungkin pada seorang pelukis, penyelenggara, dan masyarakat yang melihat dan mengapresiasi karya lukisan yang di pameran. 
Lahirnya karya lukisan itu mempunyai prosedur, membuat permasalahan yang menjadi temanya, sudah terintergrasi dalam prosedur berkarya. Langkah selanjutnya dilakukan oleh seorang pelukis dengan memikirkan dan mendiskusikan pameran lukisan bersama, agar dapat mencapai tujuan yang diinginkan.

Walter Hopps dalam wawancara dia menyatakan, "Bagiku karya-karya seniman tertentu selalu memiliki kompoissi musikal tersendiri yang harus anda coba pahami. la menempatkan kita pada kondisi psikologis tertentu. (...) Untuk bisa menguratori karya seorang seniman dengan baik.. yakni dengan menyajikannya dalam bentuk pameran... menuntut pemahaman yang seluar dan sesensitif mungkin dari seorang kurator. Pemahaman ini harus melampaui apa yang sebenar-benarnya nampak dan tertata dalam ruang pamer."

Harald Szeemann merumuskan "kurator" sebagai austellungmacher yang bisa dimaknai "pembuat pameran" (exhibition maker). Kurator menentukan bagaimana sebuah pameran seharusnya dinikmati oleh pemirsanya. Kurator harus bertanggung jawab pada alokasi/pemilihan ruangan (baik permanen maupun temporer, di luar atau di dalam galeri atau museum), penempatan karya-karya dan alur penonton; jarak dan ketinggian mata (eye level), ukuran penumpu; warna dinding, lantai dan atap, pencahayaan, jenis lampu dan sebagainya. Szeemann menyarankan untuk memahami semua aspek fisikal dan spasial itu secara puitik, sehingga sebuah pameran dapat menciptakan "puisi pendek, drama atau bahkan kekacauan yang nyata" (Agung Hujtnikajennong 2015:118 - 121)

Dengan jalan menganalisis dan mengidentifikasi karya seni lukis masing, untuk dipresentasikan, dan dicari titik temu dari hasil analisis dan identifikasi menjadi sebuah abstraksi. Kemudian 
dirumuskan dalam sebuah tema dalam sebuah pameran seni lukis bersama.

Tetapi itu menjadikan karya seni lukis itu memang harus dipresentasikan sebagai bagian dari proses berkesenian. Dengan demikian persentasi dalam pameran itu menjadi lebih melengkapi pameran tersebut. Hasil karya lukisan yang di pamerkan menjadi lebih berbicara secara baik atau sebaliknya mengurangi event pameran itu.

Untuk itu perlu adanya konsep langkah-langkah yang harus dipersiapkan oleh seorang pelukis, agar bisa melengkapi pameran itu menjadi tepat sasar, mampu diapresiasi oleh masyarakat umum. Peristiwa pameran inilah yang menjadikan seorang pelukis menjadi lebih paham dan mampu untuk melihat karya lukisan dalam realitas sosial budaya. Sebab pameran terjadi dinamika dari realitas sosial budaya masyarakat dan realitas sosial budaya dari seorang pelukisnya, yang memerlukan dialogis.

\section{Penyelenggaraan Pameran Seni Lukis}

Pembelajaran di dalam berkarya seni lukis selain membuat karya seni lukis. Diperlukan juga untuk mengetahui manajamen seni, sebagai langkah selanjutnya di dalam mempresentasikan karya seni lukis pada masyarakat. Untuk itu perlu perencanaan dalam mempersiapkan di dalam membuat pameran seni lukis.

Dengan membuat langkah-langkah apa saja yang dilakukan. Hal ini juga yang berkaitan dengan persiapan pameran sebagai seorang pelukis. Diantarnya untuk bekerjasama dengan orang lain, dalam hal ini diantara para pelukis, dengan menentukan display karya seni lukis di dalam ruang pameran.

Selain pengetahuan tentang manajemen seni dalam mendisplay seni lukis, untuk mensinkronisasikan dengan karya seni lukis satu dengan yang lainnya. Begitu juga dalam mem- 
persiapan tujuan dari pameran yang ingin disampai untuk dapat mencapai sesuatu yang menjadi tujuan. Menjadikan sebuah pameran mempunyai tujuan yang ingin dicapai.

Strategi berkarya seni lukis berlanjut pada sebuah pelaksanaan di dalam membuat karya seni. Dan hal lainnya yang berkaitan dengan seni lukis dalam perjalanannya setelah selesai menjadi karya seni lukis. Di dalam sebuah ruang pameran menjadi refleksi seorang pelukis secara obyektif di dalam membuat karya seni lukis.

Perencanaan di dalam berkarya seni lukis selain membuat karya seni lukis. Diperlukan juga untuk mengetahui manajamen seni, sebagai langkah selanjutnya di dalam mempresentasikan karya seni lukis pada masyarakat. Untuk itu perlu perencanaan dalam mempersiapkan di dalam membuat pameran seni lukis. Dengan membuat langkah-langkah apa saja yang dilakukan.

Hal ini juga yang berkaitan dengan persiapan sebagai seorang pelukis. Untuk bekerjasama dengan orang lain, dalam hal ini diantara para pelukis, dengan menentukan display karya seni lukis di dalam ruang pameran.

Selain pengetahuan tentang manajemen seni dalam mendisplay seni lukis, untuk mensinkronisasikan dengan karya seni lukis satu dengan yang lainnya. Begitu juga dalam mempersiapan tujuan dari pameran yang ingin disampai untuk dapat mencapai sesuatu yang menjadi tujuan. Menjadikan sebuah pameran mempunyai tujuan yang ingin dicapai.

Mendasain sebuah gagasan pameran karya lukisan berbasis realitas sosial budaya sebagai instrument yang dapat memberikan kemudahan dalam mencapai tujuan dari pameran. Langkah yang diambilnya adalah membuat publikasi melalui media elektronik maupun cetak. Sebagai media apresiasi mau menyebar luaskan gagasan berkeseniannya. 
Bukan sekedar pameran, atau pameran memang sesuatu yang sudah lazim yang dilakukan seorang pelukis untuk mengadakan pameran. Menjadi lebih berarti ketika teknologi pendidikan berbasis sosial budaya itu menjadi sebuah kerangka ber-pikir dari seorang pelukis di dalam berkarya seni lukis dengan segala macam tahapannya, dan pameran ini menjadi bagian yang penting setelah berkarya seni lukis.

Di dalam perkembang seni rupa muncul dengan istilah kurator, seorang yang membantuk seorang pelukis di dalam mengadakan pameran. Istilah kurator menurut kamus besar bahasa Indonesia mempunyai pengertian 1) pengurus atau pengawas harta benda orang yang pailit dan sebagainya; 2) anggota pengawas dari perguruan tingg, penyantun, 3) pengurus atau pengawas museum (gedung pameran seni lukis, perpustakaan, dan sebagainya);

Kurator menurut wikipedia bahasa Indonesia, ensiklopedia bebas adalah pengurus atau pengawas institusi warisan budaya atau seni, misalnya museum, pameran seni, galeri foto, dan perpustakaan. Kurator bertugas untuk memilih dan mengurus objek museum atau karya seni yang dipamerkan.

Kurator memiliki pendidikan tinggi dalam bidangnya, umumnya doktor atau magister dalam bidang sejarah, sejarah seni, arkeologi, antropologi, atau klasika. Kurator harus berperan aktif dalam bidangnya, misalnya memberikan seminar, menerbitkan artikel, dan menjadi pembicaran pada konferensi akademik. Kurator juga perlu mengetahui pasar serta paham kode etik dan hukum yang berlaku dalam mengumpulkan barang antik atau seni.

Kurator pameran seni lukis atau seni rupa jauh lebih mempunyai peran penting dalam terselenggaranya sebuah pameran dengan melakukan riset dan menjelaskan karya seni lukis atau seni rupa yang dipamerkan. Untuk menemukan bentuk pameran 
sebagai sebuah landasan berpikir yang terbuka dan memberikan kemungkinan. Bahwa kuratorial tidak lepas pada landasan berkarya seni lukis, memungkinkan mahasiswa bisa melihat ruang pameran sebagai sebuah karya seni lukis yang berkelanjutan. Untuk itu bisa dilihat bagaiman gaya kekuratoran Alfred $\mathrm{H}$. Barr Jr dipengaruhi oleh iklim dan komunitas akademik yang menjai lingungan domimannya sebelum menjadi sebagai direktuf museum.

Analisis formalnya mencerminkan gaya mengajarnya sebagai seorang dosen. la hanya menyampaikan interpretasi empiris, melalui apa yang memang terlihat, dengan perspektif sistematis yang menyerupai pendekatan ilmiah. "Kesempurnaan", "kebebasan", dan "kebenaran", bagi Barr, adalah hasil kerja yang harus dicapai oleh seorang seniman (Kantor, 2002:363). Kebebasan bereksperimen harus membebaskan seni dari sebagai proses ilmiah ketimbang filosofis.

Sementara kesempurnaan memungkinkan seorang seniman untuk berpartisipasi dalam proses kemajian. Baginya, ketiga nilai itu harus dibenarkan oleh praktik seni rupa modern dan diacu dalam proses penilai estetik, termasuk dalam menyeleksi karyakarya dalam pameran. Demikianlah cara Barr berkontribusi pada model praktik kuratorial berbasiskan seni rupa modern ( Agung Hujatmikajennong, 2015; 117).

Pameran seni lukis yang dilakukan secara bersama menjadi keterkaitan karya satu dengan yang lainnya, sehingga memerlukan evaluasi secara keseluruhan. Apa yang telah dilakukan dalam berkarya, sebagai sebuah gagasan untuk memberikan satu landas sani lukis secara bentuk dan secara konseptual dari sebuah pengetahuan seni. Dengan demikian seni lukis menjadi pengetahuan dan pengalaman yang memberikan pemahaman pada sebuah masyarakat dan kehidupan masyarakat. 
Bahwa karya seni lukis bisa dilihat sebagai bentuk dan kemampuan teknik. Begitu juga karya seni lukis dalam sebuah pameran bisa dilihat sebagai pengetahuan seni dan karya seni konseptual. Sebab pameran itu melihatkan segalam macam unsur dan pemahaman tentang seni sebagai pengetahuan seni. Untuk bisa melihat seni sebagai sebuah pengetahuan yang direpresentasi melalui karya seni lukis atau benda tertentu yang menjadi bagian dari karya seni.

Dengan demikan seni lukis sebagai bentuk dan teknik yang baik, sebagai mediasi gagasan dari pengetahuan seni yang menjadi karya seni yang didapat dari benda sehari-hari yang dapat di pamerkan. Seperti apa yang dilakukan Marcel Cump. Bentuk benda itu dapat dilihat dari kehidupan realitas sosial budaya yang selalu mengalami perkembangan, baik dari karya seni lukis, pengetahuan, perubahan realitas sosial budaya. Di dalam menstimulasi kehidupan masyarakatnya berdasarkan realitas sosial budaya.

Dan seni yang dipahami oleh nilai agama akan mampu membuka kesadaraan dari sebuah makna dan nilai kehidupan yang mempunyai konsep keindahan. Berkembang sebagai kehidupan yang menggagumkan, di dalam menjelajahi kehidupan, karena banyak menemukan nilai dan bentuk di luar kesadaran serta pemahaman manusia. Yang sebelumnya tidak terpikirkan dan disadari tentang nilai keindahan yang berkembangan dalam realitas kehidupan ini.

Untuk melihat sejauh mana karya seni lukis sesuai dengan apa yang menjadi ide dan gagasan berkarya. Pameran seni lukis yang menjadi representasi ini bisa menjadi sebuah evaluasi dari karya lukis itu memang sesuai atau tidak tercapai ide dalam karya seni lukis yang dibuatnya. Atau bisa saja karya seni lukisnya itu 
ini menjadi bagian dari apresiasi masyarakat, yang juga direpresentasi oleh media massa maupun eletronik, sehingga memberikan pengalaman berbeda.

Karya lukisan yang di pamerkan kemungkinan untuk membuka dialog sebagai relasi masyarakat. Pameran menjadi realitas sosial budaya dari karya seni lukis yang dipamerakan. Menjadi lebih memberikan kemungkinan bagi setiap orang untuk melihat sebagai sebuah pengalaman dan pengetahuan.

Berkarya seni lukis seorang pelukis harus mempunyai paradigma berpikir yang lebih menyeluruh. Dalam melihat segala permasalahannya. Tidak terpaku pada satu hal, baik itu masalah teknis, tema, bentuk dan keindahan.

Kesadaran ini mengembangkan pada pemahaman bahwa apa yang dilakukan dalam berkarya seni lukis itu selalu berkaitan dengan kehidupan. Seni lukis menjadi satu kesatuan dari kehidupan seorang pelukis, sebagai warna kehidupan yang ada di lingkup masyarakat menjadi sebuah sistem sosial budaya berkembang sebagai sebuah dinamika realitas sosial budaya.

Berkarya seni lukis bukan sebagai sesuatu ketrampilan, tapi memang sebagai sebuah kebutuhan dalam realita sosial budaya. Untuk bisa berperan serta dalam perkembangan kehidupan berbangsa dan bernegara dari aspek kehidupan realitas sosial budaya, untuk selalu dikembangkan. Karya seni lukis menjadi lebih berarti bagi kehidupan sosial budaya dalam arti sebenarnya.

\section{Pedoman Pameran Seni Lukis}

Untuk itu perlu adanya pedoman pameran mahasiswa studio lukis, diantaranya karya tugas yang sudah selesai dipresentasi dan diperbaiki. Pameran berlangsung selama ujian tengah semester. Sebuah persiap yang memang dirancang dengan setiap minggu pertemuan secara berkala. 
Dengan demikian akan menyempurnakan, memberikan kebebasan dan kebenaran dari sebuah karya pada dasar yang telah ditentukan. Kebenaran bentuk, kebenaran tahapan implementasi, kebenaran teknik dan kebenaran rencana pameran yang ingin dipersiapkan.

Setiap mahasiswa menjelaskan karya seni lukis yang selama ini dikerjakan selama setengan semester. Sebagai penjelasan dan pemahaman di dalam proses berkarya seni lukis sehingga menghasilkan beberapa karya seni lukis, yang nantinya akan dipamerkan secara bersama.

Pameran peserta mahasiswa sebagai seorang pelukis, mempersiapkan gagasan pameran. Sebagai bentuk gagasan yang lahir dari diskusi sesama mahasiswa. Saling memberikan pandangan dalam berkesenian, untuk menemukan bentuk satu kesatuan dalam sebuah gagasan pameran. Untuk menentukan tema pameran yang akan diselenggarakan dan menggambarkan gagasan bersama dalam pameran tersebut.

Dengan demikian pameran bersama itu akan terlihat sebuah gagasan bersama dari masing-masing karya yang dipamerkannya. Selain itu juga harus memenuhi administrasi yang telah ditentukan oleh pihak penyelenggara pameran. Berkaitan dengan perizinan, penentuan waktu, perlengkapan dan sarana lainnya.

Dengan demikian dilanjutkan dengan mendesain pameran dan mendisyaplay karya lukisan, salah satu agar bisa dilihat oleh orang lain, yang ingin melihat karya lukisannya. Dilengkapi dengan name tag dari judul karya seni lukis yang dipamerkan, agar pengunjung bisa dipandu dalam melihat pameran lukisan tersebut. Melihat judul karya seni lukis berkaitan dengan karya seni lukis yang dibuatnya. Antara karya dan judul karya seni lukis untuk memperjelas dan dimengerti. 


\section{DAFTAR PUSTAKA}

1. Abdul Jauwud, M Ahmad. 2002. Mengembang Inovasi Dan Kreatifitas Berfikir. Jakarta: Syamil Cipta Media.

2. Philip, Berrill. 2008. Everyone's Guide to Oil Painting, Berrill Philip Internasional Ltd. Terjemahan. Jakarta: Penerbit Akademia Jakarta.

3. Philip, Berrill. 2008. Everyone's Guide to Water Colour Painting. Berrill Philip Internasional Ltd. Terjemahan. Jakarta: Penerbit Akademia Jakarta.

4. Philip, Berrill. 2008. Everyone's Guide to Pastel Painting, Berrill Philip Internasional Ltd. Terjemahan. Jakarta: Penerbit Akademia Jakarta.

5. Craff Anna. 2000. Creatifity Across The Primary Curriculum. London: Routledge.

6. Brian, Clegg \& Brirch Paul. 2001. Instant Creativity. Jakarta: Defit Prima Karya.

7. Julia, Cameron \& Bryan Mark. 1992. The Artist's Way: A Spiritual Path To Higher. USA: Tarcher.

8. Nasbahry, Couto \& Minarsih. 2009. Seni Rupa, Teori dan Aplikasi. Padang Panjang: Penerbit UNP Press.

9. Sulasmi, Darmaprawira. 2002. Warna Dan Kreativitas Pengunaannya, Bandung: Penerbit ITB Bandung.

10. Walter, Dick. 2009. The Systematic Design of Intruction, London: Pearson Education Ltd.

11. Brewster, Ghiselin. 1983. The Creativity Process, Jakarta: Penerbit Gunung Jati.

12. Jonathan, Grumph 2003. The Wizard of Ideas.

13. Hujatnikajennong, Agung. 2015. Kurasi dan Kuasa, Tangerang: Penerbit Marji Kiri.

14. Heraty Toeti. 2004. Makalah "Seni Dan Metodologi: Tinjauan Filsafat Seni". Yogyakarta. 
15. Izhab Hassoubah Zaleha , 2002 "Developing Creative And Critical Thingking Skills"

16. J. Burler Miranda, 2003 "Menggali Kekuatan Intuisi"

17. Utami, Munandar. 1984. Mengembangkan Bakat Dan Kreatifitas. Jakarta: Gramedia.

18. Peuresen, C.A.Van. 1976. Strategi Kebudayaan, Yogyakarta: Penerbit Kanisius.

19. Yasraf, Piliang Amir. 1998. Sebuah Dunia Yang Dilipat. Bandung: Penerbitan Mizan.

20. Geoffry, Petty. 1997. How To Be A Better At Creativity

21. Read, Herbert. 2000. The Meaning Of Art. Terjemahan Soedarso SP. Yogyakarta: Penerbit Duta Wacana University Press.

22. Dadan, Rusmana. 2014. Filsafat Semiotika. Bandung: Penerbit Pustaka Setia.

23. Sony Kartika Dharsono, 2004. Seni Modern

24. Sony Kartika Dharsono, 2004. Pengantar Estetika.

25. Atwi, Suparman M. 2011. Desain Instruksional. Jakarta: Penerbit Universitas Terbuka Jakarta.

26. Dedya, Suardi. 2000. Komposisi Warna. Bandung: Penerbit Remaja Rosdakarya.

27. Sutrisno, Mudji \& Putranto, Hendar. 2005. Teori-Teori Kebudayaan. Yogyakarta: Penerbit Kanisius.

28. Schari, Agus. 2007. Budaya Visual Indonesia, Jakarta: Penerbit Erlangga.

29. T, Saradayrin. 2004. Menguak Kekuatan Fikiran.

30. Joyce, Wycoff. 1991. Creativity And Problem Solving.

31. The Oxford Dictionary of Philosophy. 2008. Oxford University Press, edisi bahasa Indonesia, Yogyakarta: Penerbitan Pustaka Pelajar.

32. Jim, Wheeter. 1998. The Power Of Innovative Thinking. 
33. Wiyoso, Yudoseputro. 2004. Makalah "Metode Peneletian Seni Rupa".

Data dari Internet

- kompetiblog2013.wordpress.com

- wahw33d.blogspot.com

- brembe.blogspot.com

- 3aruwiratno.wordpress.com

- www.sindoweekly-magz.com

- www.jakarta.go.id

- www.tamanismailmarzuki.com

- blog-senirupa.blogspot.com

- http://lemabang.files.wordpress.com/2013/01/sungai_limbungansketsa_usha_kismada1.jpg?w=620\& $\mathrm{h}=290$

- http://www.voaindonesia.com/content/polisi-as-temukankembali-karya-picasso-yang-dicuri-125203814/95293.html

- http://allmy.blogdetik.com/2012/12/24/pengertian-sketsa/

- http://yusuf-fybs.blogspot.com/2012_04_29_archive.html

- http://reddamuralart.wordpress.com

- http://ranaberita.com/?p=303

- www.oktomagazine.com/arsip

- highered.mcgraw-hill.com/sites/.../GetleinCh7

- http://en.wikipedia.org/wiki/Category:Painting_techniques

- http://theportraitplace.co.uk/arttechneg.php 
Seni Lukis, Kansep dan Metade 